Prepared in cooperation with the UNIVERSITY OF NEBRASKA-LINCOLN and the CITY OF LOUP CITY, NEBRASKA

Use of Water Chemistry, Isotopes, and Chlorofluorocarbons to Investigate the Sources of Ground Water Beneath Loup City, Central Nebraska, 2000

Water-Resources Investigations Report 02-4049

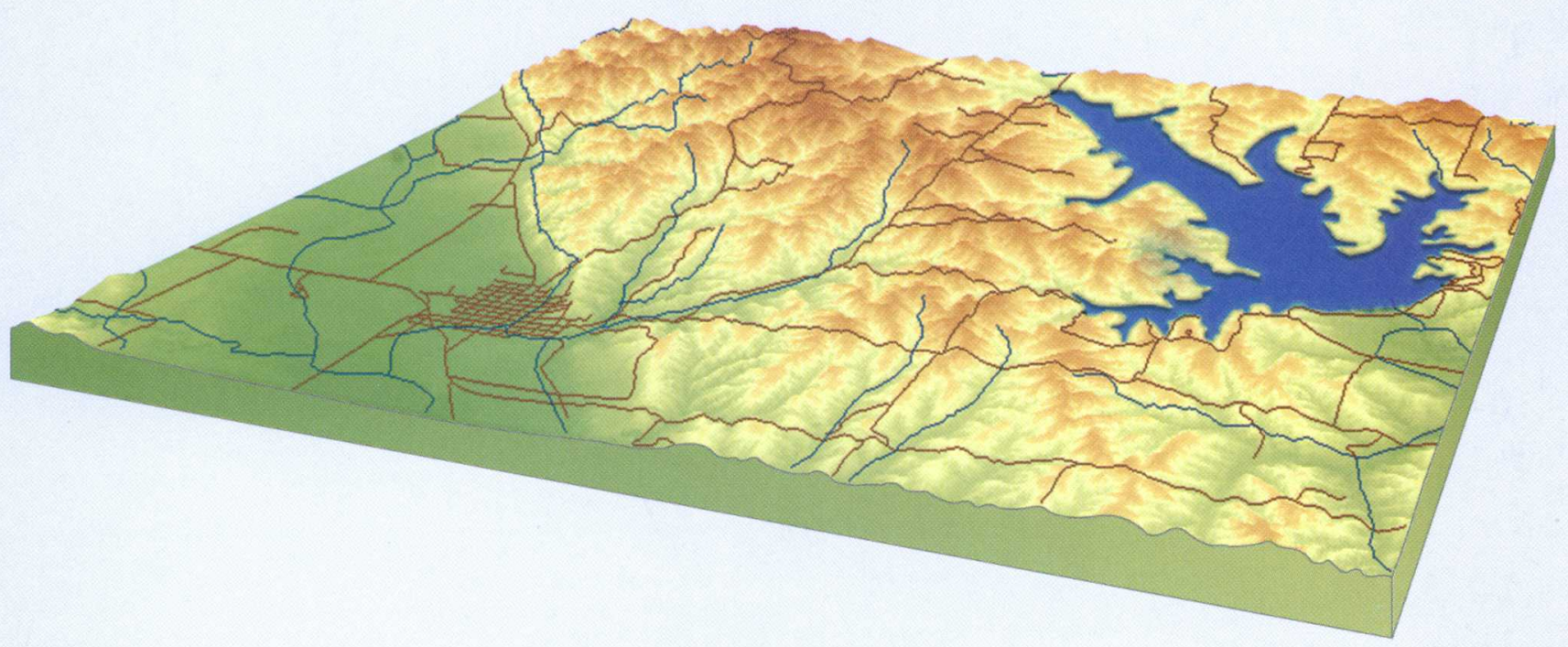



Use of Water Chemistry, Isotopes, and Chlorofluorocarbons to Investigate the Sources of Ground Water Beneath Loup City, Central Nebraska, 2000

By G.V. STEELE and F. EDWIN HARVEY

Water-Resources Investigations Report 02-4049

Prepared in cooperation with the

UNIVERSITY OF NEBRASKA-LINCOLN and the

CITY OF LOUP CITY, NEBRASKA 


\section{U.S. Department of the Interior \\ Gale A. Norton, Secretary}

\section{U.S. Geological Survey}

Charles G. Groat, Director

The use of firm, trade, and brand names in this report is for identification purposes only and does not constitute endorsement by the U.S. Geological Survey.

Lincoln, Nebraska: 2002

For additional information write to:

\section{District Chief}

U.S. Geological Survey

406 Federal Building

100 Centennial Mall North

Lincoln, NE 68508

Copies of this report can be purchased from:

\section{U.S. Geological Survey}

Information Services

Building 810

Box 25286, Federal Center

Denver, CO 80225-0286 


\section{CONTENTS}

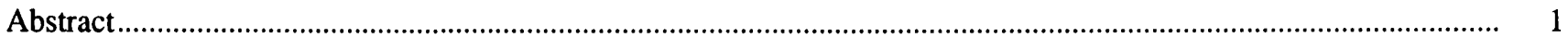

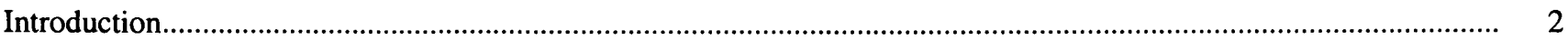

Purpose and Scope

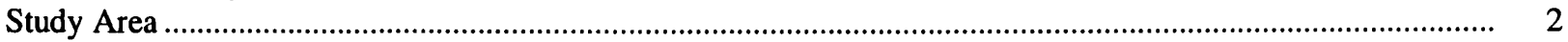

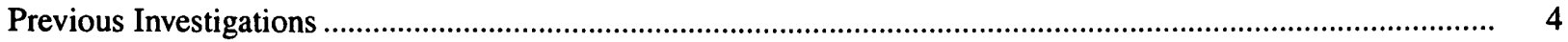

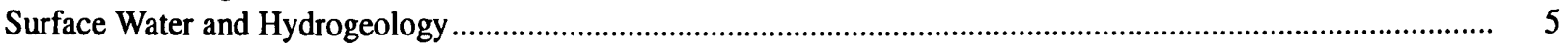

Methods

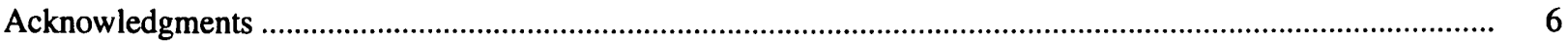

Site Selection

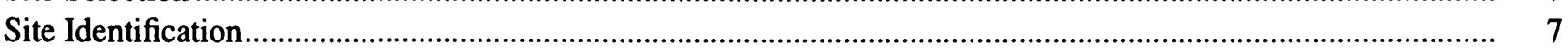

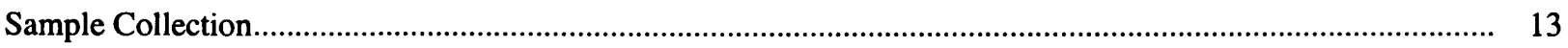

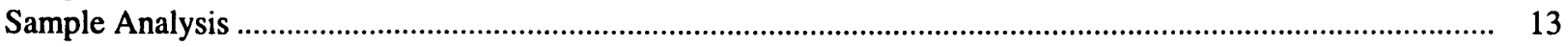

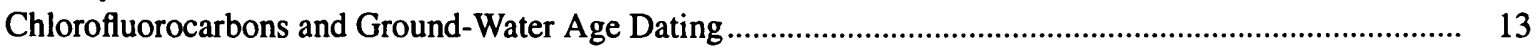

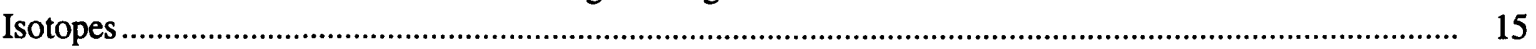

Oxygen-18 and Deuterium ................................................................................................... 15

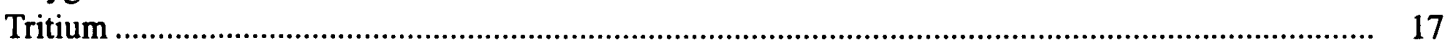

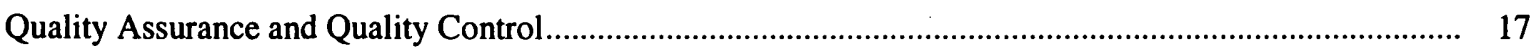

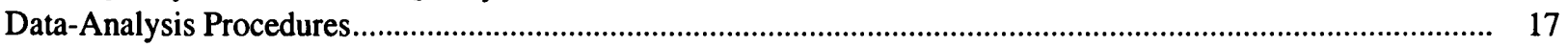

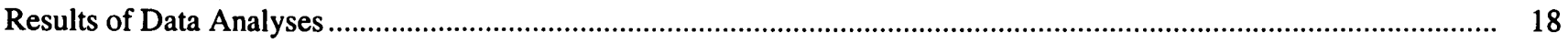

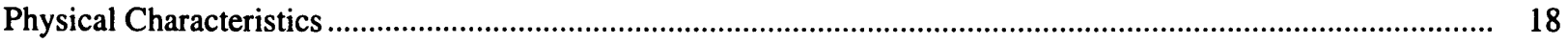

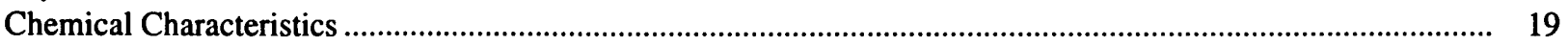

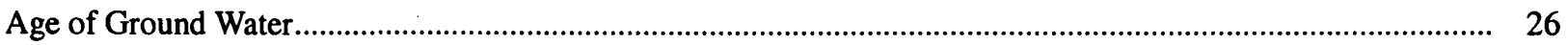

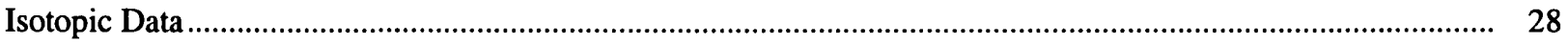

Oxygen and Hydrogen .................................................................................................................. 28

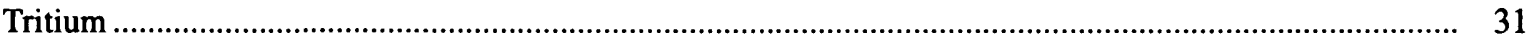

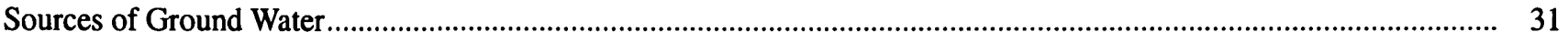

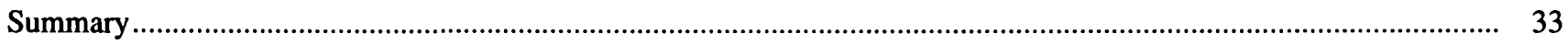

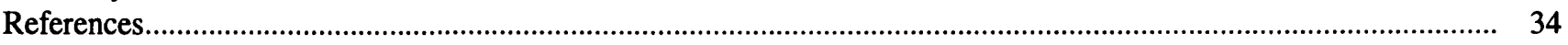

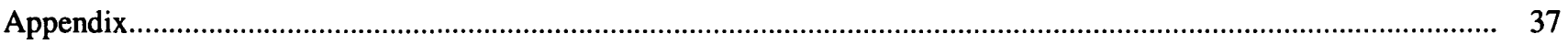

FIGURES

1. Maps showing location of study area, central Nebraska ......................................................................... 3

2. Map showing locations of surface-water and ground-water sampling sites and generalized geologic section in study area

3. Map showing configuration of water table in study area, before construction of Sherman Reservoir and during 2000

4. Schematic diagram of well-numbering system...

5. Graphs showing atmospheric concentrations of chlorofluorocarbons CFC-11, CFC-12, and CFC-113 in North American air and tritium concentrations in precipitation from Ottawa, Ontario, Canada, and Lincoln, Nebraska

6. Graph showing mixing of ground-water source with an evaporated water source, such as a reservoir...

7. Graph showing depth to water table in selected Bureau of Reclamation observation wells in study area

8. Box plots showing distribution of physical properties and water-quality constituent concentrations by source in study area, 2000 .

9. Trilinear diagram showing ionic composition of surface water and ground water in study area, 2000 ..

10. Graphs showing oxygen $\left(\delta^{18} \mathrm{O}\right)$ and stable hydrogen $\left(\delta^{2} \mathrm{H}\right)$ composition of water samples from study area for March and April 2000, and July 2000.

11. Graphs showing tritium concentrations in water samples collected from study area in 2000 and back calculated to estimate historic concentrations. 
1. Geohydrologic characteristics of study area in central Nebraska

2. Sites selected for surface-water sampling and construction data for wells sampled in study area, central Nebraska

3. Results of measurements of physical properties in surface and ground water in study area, central Nebraska, 2000

4. Minimum, maximum, and quartile constituent concentrations by water source in study area, central Nebraska, 2000

5. Results of chlorofluorocarbon age-dating analyses of water samples in study area, central Nebraska, 2000

6. Averaged modeled age of water samples from study area in central Nebraska analyzed for chlorofluorocarbons and tritium, 2000

7. Isotopic chemistry data for water samples collected in study area, central Nebraska, 2000.

8. Results of water-quality analysis for major ions in water samples from study area, central Nebraska, 2000

9. Results of water-quality analysis for nutrients in water samples from study area, central Nebraska, 2000

CONVERSION FACTORS AND VERTICAL DATUM

\begin{tabular}{rcl} 
Multiply & By & To obtain \\
inch (in.) & Length & centimeter \\
foot (ft) & 0.3048 & meter \\
mile (mi) & 1.609 & kilometer \\
& Area & \\
acre & 4,047 & square meter \\
square foot ( $\mathrm{ft}^{2}$ ) & 0.09290 & square meter \\
& Volume & \\
gallon (gal) & 3.785 & liter \\
million gallons (Mgal) & 3,785 & cubic meter 、 \\
acre-foot (acre- $\mathrm{ft}$ ) & 1,233 & cubic meter \\
& Flow rate & \\
cubic foot per second ( $\mathrm{ft}^{3} / \mathrm{s}$ ) & 0.02832 & cubic meter per second \\
gallon per minute (gal/min) & 0.06309 & liter per second \\
foot per day (ft/d) & 0.3048 & meter per day \\
Hydraulic gradient & \\
foot per foot & 0.3048 & meter per meter \\
foot per mile (ft/mi) & 0.1894 & meter per kilometer \\
\hline
\end{tabular}

Temperature in degrees Celsius $\left({ }^{\circ} \mathrm{C}\right)$ may be converted to degrees Fahrenheit $\left({ }^{\circ} \mathrm{F}\right)$ as follows: ${ }^{\circ} \mathrm{F}=\left(1.8 \cdot{ }^{\circ} \mathrm{C}\right)+32$.

Temperature in degrees Fahrenheit $\left({ }^{\circ} \mathrm{F}\right)$ may be converted to degrees Celsius $\left({ }^{\circ} \mathrm{C}\right)$ as follows: ${ }^{\circ} \mathrm{C}=\left({ }^{\circ} \mathrm{F}-32\right) / 1.8$.

Sea level: In this report, "sea level" refers to the National Geodetic Vertical Datum of 1929 (NGVD of 1929)-a geodetic datum derived from a general adjustment of the first-order level nets of both the United States and Canada, formerly called Sea Level Datum of 1929.

Altitude, as used in this report, refers to distance above or below sea level.

Specific conductance is given in microsiemens per centimeter at 25 degrees Celsius $\left(\mu \mathrm{S} / \mathrm{cm}\right.$ at $\left.25^{\circ} \mathrm{C}\right)$.

Concentrations of chemical constituents in water are given either in milligrams per liter $(\mathrm{mg} / \mathrm{L})$ or micrograms per liter $(\mu \mathrm{g} / \mathrm{L})$. 


\title{
Use of Water Chemistry, Isotopes, and Chlorofluorocarbons to Investigate the Sources of Ground Water Beneath Loup City, Central Nebraska, 2000
}

\author{
By G.V. Steele ${ }^{1}$ and F. Edwin Harvey ${ }^{2}$
}

\section{Abstract}

Ground-water levels near Sherman Reservoir have risen locally more than 85 feet since the Bureau of Reclamation (U.S. Department of the Interior) constructed the reservoir in 1962. Loup City, about 2.5 miles west-southwest of Sherman Reservoir, has experienced high ground-water levels in parts of the city. Local officials have attributed these high ground-water levels to seepage from Sherman Reservoir. In 2000, the U.S. Geological Survey, the University of Nebraska-Lincoln, and the city of Loup City began a cooperative study to investigate the sources of the ground water beneath Loup City. As part of this study, 24 surface- and groundwater sites were selected and sampled for physical properties, major ions, nutrients, and selected isotopes-oxygen-18, deuterium, and tritium. In addition, water samples from a subset of these sites were analyzed for chlorofluorocarbons to estimate the age of the water.

Results of analysis of surface-water and ground-water samples showed that water from both sources was similar and predominantly a calcium bicarbonate type. Evaporation from Sherman Reservoir does not appear to be concentrating chemical species in the lake. However, water varied more in chemistry between ground-

\footnotetext{
${ }^{1}$ U.S. Geological Survey, Lincoln, Nebraska.

${ }^{2}$ University of Nebraska-Lincoln, School of Natural Resource Sciences and Conservation and Survey Division, Lincoln, Nebraska.
}

water sites than between surface-water sites. Most domestic wells and the observation wells in the alluvial aquifer underlying Loup City had large calcium concentrations. Bureau of Reclamation observations wells, on the other hand, typically contained larger sodium concentrations.

Ground-water age dating indicated that the modeled age of the ground water underlying Loup City ranged from the mid-1940s to the early 1960s. Analyses of water samples from a domestic well near Sherman Reservoir indicated that recharge occurred during the mid-1970s. Except for this single well, all other data indicated that although seepage of water from Sherman Reservoir locally has changed the regional groundwater flow paths, the ground water beneath Loup City predates construction of Sherman Reservoir.

Oxygen-18 and deuterium data indicated that there is substantial evaporative enrichment at Sherman Reservoir. However, this enrichment was not detected in most ground-water samples from wells in Loup City. In the two wells in Loup City that did show a strong evaporative signature, the source of the water likely was from a nearby canal and not Sherman Reservoir.

The sources of the water beneath Loup City cannot be accurately determined from available data. However, from analysis of the water chemistry and isotope data, it appears that the water underlying Loup City does not show evidence of a Sherman Reservoir component. 


\section{INTRODUCTION}

In 1962, the Bureau of Reclamation (BOR), U.S. Department of the Interior, completed Sherman Reservoir, about 2.5 mi east northeast of Loup City, Sherman County, Nebraska (fig. 1). Sherman Reservoir is used primarily to supply irrigation water to the Farwell Irrigation District and used secondarily for recreational purposes. Sherman Dam, which impounds the water in the reservoir, is "a homogeneous rolled earth-filled structure," 4,450 ft long at the crest and $134 \mathrm{ft}$ high (Nebraska Game and Parks Commission, 2000). Sherman Reservoir creates about $65 \mathrm{mi}$ of shoreline with a surface area of about 2,878 acres and a storage pool of about 69,076 acre-ft (Nebraska Game and Parks Commission, 2000). Typically, to fill Sherman Reservoir, water is diverted in March or April from the Middle Loup River at the Arcadia diversion dam south of Comstock, Nebraska (Karl Wadas and Harold 'Butch' Turek, Nebraska Department of Natural Resources, oral commun., 2000) into the 18-mi long Sherman Reservoir Feeder Canal. The diversions continue throughout the irrigation season (May through September) for subsequent release to irrigate about 50,000 acres of farmland downstream of Sherman Reservoir. Water also is diverted from the Sherman Reservoir Feeder Canal to the Middle Loup Public Power and Irrigation District's Canal Number 4 (herein referred to as Canal 4) that flows through Loup City. Canal 4, completed in 1938 (Brown, 1955), is used to irrigate land in southwest Valley and Sherman Counties.

In 1974, BOR installed two subterranean drains in Loup City to address concerns the citizens of Loup City and the rural area had regarding rising groundwater levels in and around Loup City. These drains were installed to lower ground-water levels in Loup City to levels at or below those in existence before Sherman Reservoir was constructed.

BOR (Bureau of Reclamation, 1989) reported that a combination of above-normal rainfall, seepage losses from Canal 4 and its laterals, irrigation use, and the potential development of a seepage mound from Sherman Reservoir might have contributed to the high ground-water levels in the Middle Loup River Valley. BOR (Bureau of Reclamation, 1996) reported that seepage of surface water from Sherman Reservoir was causing ground-water levels to rise in the vicinity of Loup City; however, these ground-water-level rises were slight, and Loup City had had a history of high ground-water levels. The probable cause for the then- current high ground-water levels in Loup City was an above-normal amount of rainfall that had fallen since the early 1990s. BOR (Bureau of Reclamation, 1996) maintained that the drains that were installed were keeping ground-water levels in Loup City at or below pre-Sherman Reservoir construction levels. However, officials of Loup City maintain that these drains were not lowering ground-water levels sufficiently. The U.S. Geological Survey (USGS), in cooperation with the University of Nebraska-Lincoln and the city of Loup City, began a study in 2000 to investigate the sources of ground water beneath Loup City. The techniques used in this investigation could help communities having similar conditions.

\section{Purpose and Scope}

The purpose of this report is to present the results of the study to determine if the probable sources of ground water beneath Loup City, Nebraska, are from Sherman Reservoir or other surface-water features. This report describes (1) methods used to select and install monitoring wells for water-level and waterquality data collection, (2) results of the water-level, water-quality, age-dating, and water isotopic analyses, and (3) a discussion of the possible sources of the ground water beneath Loup City.

\section{Study Area}

The study area (fig. 1) is in the High Plains Section of the Great Plains Province (Fenneman, 1946) and is characterized by hot summers and severe winters. During 1999, air temperature extremes in Loup City ranged from $-18{ }^{\circ} \mathrm{F}$ in January to $99^{\circ} \mathrm{F}$ in July (National Oceanic and Atmospheric Administration, 2000). Precipitation during 1999 totaled 26.09 in. (National Oceanic and Atmospheric Administration, 2000 ) or 0.37 in. above the 30 -year normal (1961-90) for Loup City. From 1990 to 1999 the departure of total annual precipitation from normal varied from 2.64 in. below normal in 1997 to 13.78 in. above normal in 1993 (V.L. McGuire, U.S. Geological Survey, written commun., 2001). During this same period, below-normal annual precipitation only occurred in 1994 and 1997. Precipitation departures from normal for 1990 to 1999 indicate a median of 1.22 in. above normal and a mean of $2.22 \mathrm{in}$. above normal. 


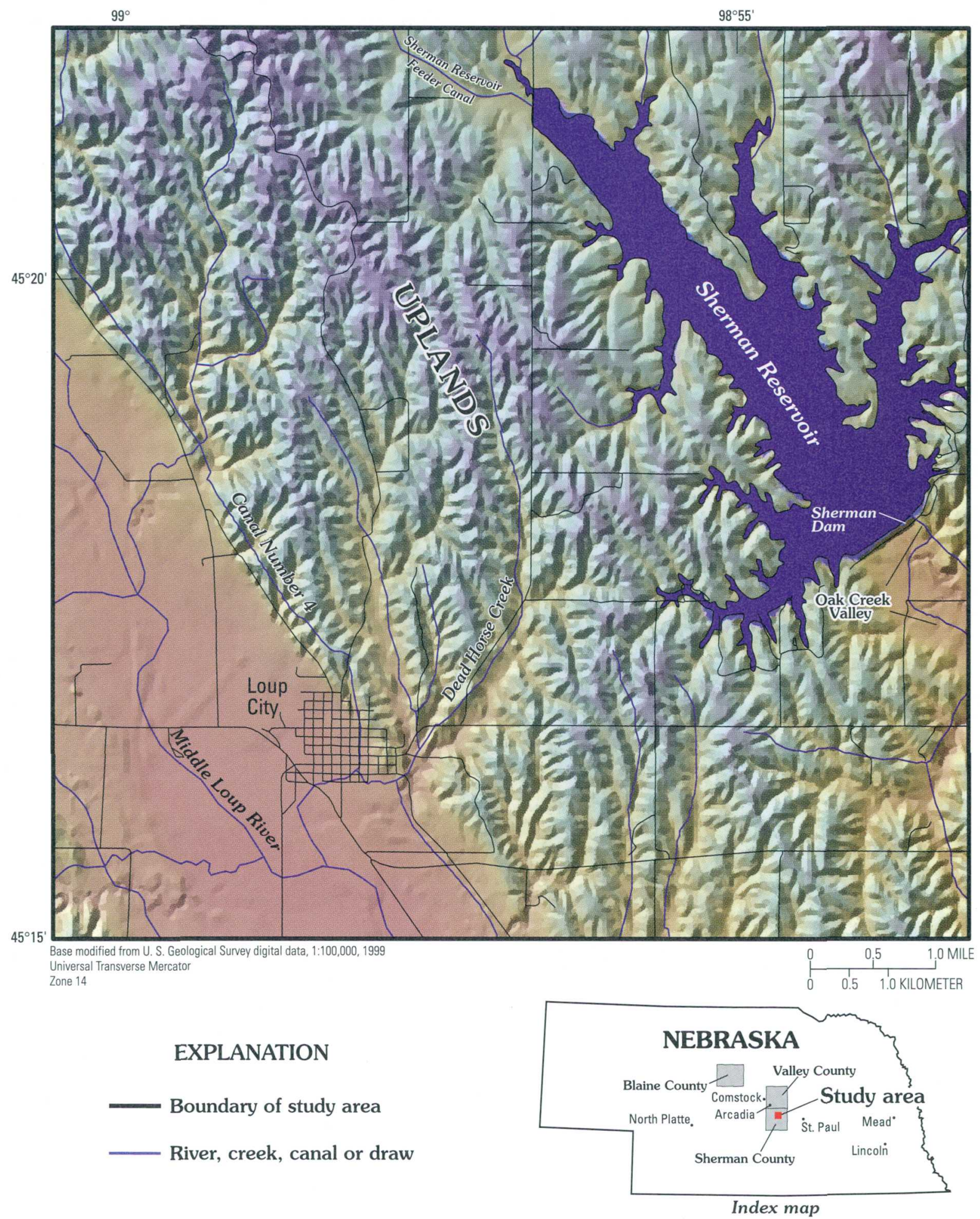

Figure 1. Location of study area, central Nebraska. 
Landforms in the study area are diverse and characterized by a nearly flat, 2-mi-wide alluvial plain of the Middle Loup River and rolling loess-mantled hills that make up the uplands. Loup City lies on the easternmost edge of the Middle Loup River Valley. However, the most prominent land feature in the study area is the loess-mantled hills that flank the Middle Loup River Valley. On the east-northeast side of Loup City, the loess-mantled hills start as bluffs and continue as rolling hills toward the northeast and east toward Sherman Reservoir (fig. 1), which lies in Oak Creek Valley. The only major surface-water feature lying between Sherman Reservoir and Loup City is Dead Horse Creek (fig. 1). Near the eastern edge of Loup City, Dead Horse Creek, which is ephemeral, has been filled in for crop cultivation. Most of the domestic wells that lie between Sherman Reservoir and Loup City are in Dead Horse Creek Valley.

\section{Previous Investigations}

Two reports that predate Sherman Reservoir (Brown, 1955, and Sniegocki, 1959) describe the regional geology, including the study area, and document the regional hydrogeology. Most of the other reports that incorporate the study area are limited to studies performed by BOR to document the groundwater conditions in and around Loup City (Bureau of Reclamation, 1989, 1996, 1999). Additional studies on general hydrology, geology, or ground-water-flow conditions include Miller and Associates Consulting Engineers, P.C. (1988) and Olsson Environmental Sciences, Inc.. (1997). Souders (2000) completed a regional geologic map ( $1^{\circ}$ latitude by $2^{\circ}$ longitude) and discussed geologic cross sections and depositional history of the region.

Brown (1955) completed a comprehensive preSherman Reservoir study of the Middle Loup River Valley from the southern edge of Blaine County to St. Paul. Brown reported that the Middle Loup River was predominantly a gaining stream in this area. Ground water typically moved from the upland areas to the Middle Loup River Valley. The only time the Middle Loup River was not a gaining stream was during times of high stage. Prior to the construction of Sherman Reservoir, depths to water in the alluvial sediment ranged from less than $10 \mathrm{ft}$ near the Middle Loup River to about $60 \mathrm{ft}$ near the margins of the Middle Loup River Valley (Brown, 1955). Brown reported that locally depths to water in the upland areas were greater than $150 \mathrm{ft}$.

Sniegocki (1959) reported geologic and groundwater conditions in the Loup River drainage basin, which includes the study area and covered a greater areal extent than Brown (1955). In addition, Sniegocki (1959) identified both water-table and confined conditions in the ground-water systems in the study area. Both Brown (1955) and Sniegocki (1959) indicated that the Middle Loup River was a gaining river and that the regional ground-water-flow direction predominantly was west-northwest to east-southeast. The water-table contour maps created by Brown (1955) and Sniegocki (1959) used sufficient data to document ground-water-flow directions in the Middle Loup River Valley. However, both reports lacked sufficient wells in the upland areas to characterize upland ground-water-flow directions.

In 1973 BOR (Chief, BOR, Drainage Branch, written commun., 2000) conducted a study to determine the feasibility of a drainage system in Loup City to lower ground-water levels to pre-Sherman Reservoir construction levels. One previous investigation that is of particular importance to this study was completed by BOR (Bureau of Reclamation, 1989). In that report, BOR evaluated ground-water conditions from the Middle Loup River to Sherman Reservoir and the seepage loss from Canal 4. The BOR study included irrigated lands along the Middle Loup River Valley several miles north and south of Loup City. Key components of the 1989 BOR report included documentation of a ground-water-flow model used by BOR to simulate ground-water levels around Sherman Reservoir and Loup City. The ground-water-flow model used by BOR was a modified version of the Illinois State Water Survey's two-dimensional, finitedifference ground-water-flow model developed by Prickett and Lonnquist (1971). Results of the BOR ground-water-flow model indicated that seepage from Sherman Reservoir had developed a mound of water that "has traveled out from the reservoir several miles and now may, or may not, be influencing the water table levels in the study area." In addition, losses of water from Canal 4 and recharge to the aquifer from local precipitation were evaluated. Constant-head ponding tests were used to quantify the loss of water from Canal 4 at two separate locations along the canal in the vicinity of Loup City. BOR concluded that loss of water from Canal 4 was occurring, and this loss was contributing seepage to ground water at Loup City. 
BOR (Bureau of Reclamation, 1996) evaluated the effects of seepage from Sherman Reservoir on the water table at Loup City. BOR updated the original ground-water-flow model of 1989 by simulation of ground-water-flow conditions in the study area through construction of a transient, two-dimensional ground-water-flow model using the USGS's modular, finite-difference ground-water-flow model, MODFLOW (McDonald and Harbaugh, 1988). BOR concluded that the simulations using the groundwater-flow model indicated that temporal changes in ground-water levels in the Loup City area are affected by several factors, including local precipitation, the Middle Loup River, BOR-installed drains, sewer-line infiltration, and Sherman Reservoir. For the current study, all of these effects, excluding precipitation, were evaluated using chemical and isotopic analyses of water samples. During the current study, precipitation amounts were insufficient for collection of samples for a complete water-quality analysis.

\section{Surface Water and Hydrogeology}

Perennial surface-water features in the study area are limited primarily to the Middle Loup River and Sherman Reservoir. However, during the irrigation season, surface water also is present in Canal 4. The Middle Loup River is a braided, sand-bed stream that derives most of its flow from ground water. The annual mean flow of the Middle Loup River at Arcadia, upstream from the study area, from 1962 to 1993, was $719 \mathrm{ft}^{3} / \mathrm{s}$ (Boohar and others, 1994). Flow of the Middle Loup River at Loup City was about $1,180 \mathrm{ft}^{3} / \mathrm{s}$ during March and April 2000 and about $188 \mathrm{ft}^{3} / \mathrm{s}$ during July 2000.

The Farwell Irrigation District operates Sherman Reservoir and maintains a pool (forebay) elevation of about $2,155 \mathrm{ft}$ above sea level. The average pool elevation was 2,155 ft in March and April, and 2,157 ft in July. Typical depths in the main pool can be as great as $50 \mathrm{ft}$. The 2,155-ft pool elevation is about $85 \mathrm{ft}$ higher than the ground-water elevation at Loup City. Therefore, a hydraulic gradient of about $0.0064 \mathrm{ft} / \mathrm{ft}$ or $34 \mathrm{ft} / \mathrm{mi}$ exists between Sherman Reservoir and Loup City.

The principal hydrogeologic units within the study area (table 1) are the saturated alluvial deposits of Holocene and Pleistocene (Quaternary) age that make up the valley fill, the alluvial deposits of Pliocene (Tertiary) age that underlie the loess deposits on the uplands, and the bedrock deposits (Ogallala Formation) of Miocene (Tertiary) age. The Ogallala Formation, which underlies the entire study area (fig. $2 B$ ), serves as the basal aquifer (herein referred to as the Ogallala aquifer), and overlies the Pierre Shale of Cretaceous age.

The Ogallala Formation predominantly is fluvial material consisting of clay, silt, clayey silt, siltstone, sand, sandstone, pebbly sandstone, and gravelly sandstone (Souders, 2000). The sand and sandstone beds of the Ogallala Formation can be well sorted, very fine to fine, and fine to medium sand, whereas the gravelly sandstone tends to be poorly sorted (Souders, 2000).

In the study area, depths to water in wells open to the Ogallala aquifer vary from less than $6 \mathrm{ft}$ under Loup City to more than $150 \mathrm{ft}$ in the uplands between Loup City and Sherman Reservoir. Olsson Environmental Sciences, Inc. (1997) reported a specific yield of 0.30 , a hydraulic conductivity of $107 \mathrm{ft} / \mathrm{d}$, and an effective porosity of 0.30 for the Ogallala aquifer (table 1), which likely are typical of the shallowest unconsolidated material in the Ogallala aquifer. Typical specific-yield and hydraulic-conductivity values ( 0.15 to 0.16 and 14 to $19 \mathrm{ft} / \mathrm{d}$, respectively) of the Ogallala aquifer likely are similar to those reported by Peckenpaugh and Dugan (1983) in an area about $18 \mathrm{mi}$ south of the study area. The predominant ground-water-flow direction in the upland areas prior to the completion of Sherman Reservoir was southsoutheasterly to east (fig. 3) (Brown, 1955). Groundwater flow in upland areas near the Middle Loup River Valley was south to southwesterly and toward the Middle Loup River. Following the completion and filling of Sherman Reservoir, the predominant groundwater-flow direction changed to west to southwesterly in areas between Sherman Reservoir and Loup City (fig. 3) (Bureau of Reclamation, 1989). In areas directly downstream of Sherman Reservoir, groundwater flow was south-southeasterly to east. During this study, water levels in the Ogallala aquifer rose locally about $30 \mathrm{ft}$ above the contact between the Ogallala aquifer and the overlying alluvial sand. This resulted in a small, but measurable ( $0.20 \mathrm{ft})$, upward groundwater head difference between the Ogallala and alluvial aquifers directly underlying Loup City.

In the uplands between Loup City and Sherman Reservoir undifferentiated loess, eolian sand, and alluvial deposits of Quaternary age and undifferentiated loess and alluvial deposits of Tertiary age (table 1) directly overlie the Ogallala Formation. The loess 
Table 1. Geohydrologic characteristics of study area in central Nebraska

[Geohydrologic characteristics from Souders (2000); ft, feet; <, less than; >, greater than; gal/min, gallons per minute; ftd, feet per day; specific-yield and hydraulic-conductivity values from Peckenpaugh and Dugan (1983) and Olsson Environmental Services, Inc. (1997)]

\begin{tabular}{|c|c|c|c|c|}
\hline System & Series & Geologic unit & $\begin{array}{c}\text { Maximum } \\
\text { thickness ( } f t)\end{array}$ & Hydrologic characteristics \\
\hline \multirow[t]{3}{*}{ Quaternary } & Holocene & Alluvium & 50 to 100 & $\begin{array}{l}\text { Silt to very coarse sand and some gravel. Yields to } \\
\text { wells about } 1,000 \mathrm{gal} / \mathrm{min} \text {. Typical values for } \\
\text { specific yield, } 0.20 \text {; hydraulic conductivity, } \\
54 \mathrm{ft} / \mathrm{d} \text {; and effective porosity, } 0.25 \text {. }\end{array}$ \\
\hline & \multirow[t]{2}{*}{ Pleistocene } & Eolian sand & $<100$ & Not considered a major water source. \\
\hline & & Loess & $<40$ & Not considered a major water source. \\
\hline \multirow[b]{3}{*}{ Tertiary } & \multirow[b]{2}{*}{ Pliocene } & Loess & $<50$ & $\begin{array}{l}\text { Not a major water source, could serve as a local } \\
\text { confining unit. }\end{array}$ \\
\hline & & Alluvium & $<50$ & $\begin{array}{l}\text { Silt to very coarse sand and some gravel. Yields to } \\
\text { wells may range from } 500 \text { to } 1,000 \mathrm{gal} / \mathrm{min} \text {. } \\
\text { Values for specific yield, hydraulic conductiv- } \\
\text { ity, and effective porosity probably similar to } \\
\text { alluvium of Quaternary age. }\end{array}$ \\
\hline & Miocene & Ogallala Formation & $>300$ & $\begin{array}{l}\text { Silt to sand and some gravel and sandstone. Yields } \\
\text { to wells about } 500 \text { to } 1,000 \mathrm{gal} / \mathrm{min} \text {. Typical } \\
\text { values may range from } 0.15 \text { to } 0.30 \text { for specific } \\
\text { yield; } 14 \text { to } 100 \mathrm{ft} / \mathrm{d} \text { for hydraulic conductivity, } \\
\text { and } 0.20 \text { to } 0.30 \text { for effective porosity. Largest } \\
\text { values of specific yield and hydraulic conduc- } \\
\text { tivity likely associated with shallowest uncon- } \\
\text { solidated material. }\end{array}$ \\
\hline Cretaceous & Upper Cretaceous & Pierre Shale & $<100$ & $\begin{array}{l}\text { Not a major water source, serves as a basal } \\
\text { confining unit. }\end{array}$ \\
\hline
\end{tabular}

deposits typically are unsaturated, but locally seepage from Sherman Reservoir probably has filled some of the fractures in the loess. The thickness of the Pliocene-age alluvium has not been measured, but it is thought to be less than $50 \mathrm{ft}$. Depths to water in these alluvial deposits could not be quantified because driller's logs were unavailable or not sufficiently detailed for the domestic wells between Loup City and Sherman Reservoir. However, because some observation wells in the uplands are only about $150 \mathrm{ft}$ deep, it is likely that they were screened in the first saturated sand and gravel deposits. No determination has been made for the specific-yield and hydraulic-conductivity values for these alluvial deposits. However, because these alluvial deposits are similar to the deposits of the alluvial aquifer in the Middle Loup River Valley, they likely have similar hydraulic properties.

The alluvial deposits that provide the fill for the Middle Loup River Valley consist of gravel, sand, and lesser amounts of silt and clay (Souders, 2000). Depth to water in these deposits, which underlie most of Loup City, ranges from less than $3 \mathrm{ft}$ near the Middle Loup River to more than $10 \mathrm{ft}$ near the break in slope of the uplands at Loup City. In March 2000, the depth to ground water was about $6 \mathrm{ft}$ at the western edge of Loup City. Olsson Environmental Services, Inc. (1997) reported a specific yield of 0.20 , a hydraulic conductivity of $54 \mathrm{ft} / \mathrm{d}$, and an effective porosity of 0.25 for the alluvial aquifer (table 1). Although the values reported by Olsson Environmental Services, Inc. (1997) are mostly site specific (in Loup City), these values are considered typical of the alluvial aquifer as a whole. The predominant ground-waterflow direction both before and since the completion of Sherman Reservoir is along and toward the Middle Loup River.

\section{Acknowledgments}

The authors acknowledge the citizens and staff of Loup City and the staff of the Farwell Irrigation District for their help during the study. Special appreciation is extended to the Honorable Mayor Norman Woitalewicz, Mark Eureck, and Robert Piontkowski, Loup City, and Darwin Lee, Farwell Irrigation District 
Superintendent, for their help in locating observation wells and multi-level monitoring-well sites.

Special appreciation also is extended to the landowners who provided access to their domestic wells for the collection of water samples: Harold and Evelyn Janulewicz, Lanny and Sharon Kizer, Norman and Donna Lewandowski, and Mrs. Mildred Norseen. Appreciation is extended to Kenneth Martin, Supervisor, Nebraska Game and Parks Commission, Sherman Reservoir Recreation Area, for providing access to the domestic well near Sherman Reservoir.

\section{METHODS}

Surface-water and ground-water samples were collected concurrently from 24 selected sites during two sampling periods-March/April and July 2000. This section describes the site selection and analytical methods used to collect these data during this study.

\section{Site Selection}

Four surface-water sites were selected for sampling-Middle Loup River at Loup City, Sherman Reservoir (two sites), and Canal 4. These sites were chosen because water from one or more of them possibly contributes to ground water beneath Loup City. Because Sherman Reservoir is large, two sites were selected for sampling - one in the primary pool, and another in an arm located close to Loup City. In addition, each of these two sites was sampled at three depths-near the bottom of the reservoir (deep), near the top of the pool (shallow), and approximately halfway between these two depths (intermediate).

Twenty-four ground-water wells (table 2) (including two monitoring-well sites and Loup City's sewerlift station discussed next) at 20 sites were selected on the basis of specific well types and location-domestic (5 wells), observation (BOR, 6 wells, and Loup City, 5 wells), monitoring-well sites (2), and public supply (1 well). All five domestic wells are in the uplands between Loup City and Sherman Reservoir. Seven of the 11 BOR and Loup City observation wells and the single public-supply well are in Loup City. The remaining four BOR observation wells are between Loup City and Sherman Reservoir.

In addition to the existing wells, two sites in Loup City were selected for installation of multi-level monitoring wells. The multi-level monitoring wells each contained three wells open at different depths--deep, intermediate, and shallow. Each deep well was open just below the top of the Ogallala Formation, whereas the intermediate and shallow monitoring wells in each cluster were open at the base (intermediate) and the top (shallow) of the overlying saturated alluvial deposits. These multi-level monitoring wells enabled the collection of vertically distributed ground-water samples.

One additional site was chosen for sampling. Loup City officials stated that ground water seeps through cracks in the storm-sewer system, and their system is overtaxed with respect to the volume of water the system treats. Therefore, Loup City's sewage lift station was chosen to represent the ground water leaving the storm-sewer drainage system. The lift system drains both the sanitary sewer and the stormsewer systems of Loup City.

To differentiate the sample sites for comparison, they were divided into three classifications or sources-surface water, alluvial aquifer (which included the Loup City sewer), and Ogallala aquifer. On the basis of its location and depth, each groundwater site was classified either as alluvial or Ogallala. The alluvial classification was used to designate those monitoring wells that were open to the alluvium in the Middle Loup River Valley. The Ogallala classification was used to designate the predominant formation of the uplands. BOR observation wells located in the uplands may not be open to the Ogallala aquifer; however, they were included in the Ogallala classification because: (1) they are in the uplands and overlie the Ogallala aquifer and (2) their open interval and the unit in which they are open are not known. Ogallala monitoring wells also included the deeper monitoring wells open to the Ogallala aquifer but located in Loup City, as well as Loup City's public-supply well.

\section{Site Identification}

This report uses three different methods of site identification (table 2). The first method uses the USGS site identification number. USGS assigns a unique number to each site (such as 06779500 for surface-water sites and 411706098582201 for groundwater sites).

For surface-water sites, the eight-digit number, sometimes extended up to 11 digits, is assigned by downstream direction along the main stream. The first two digits " 06 " represent the major river basin; which 
(A)

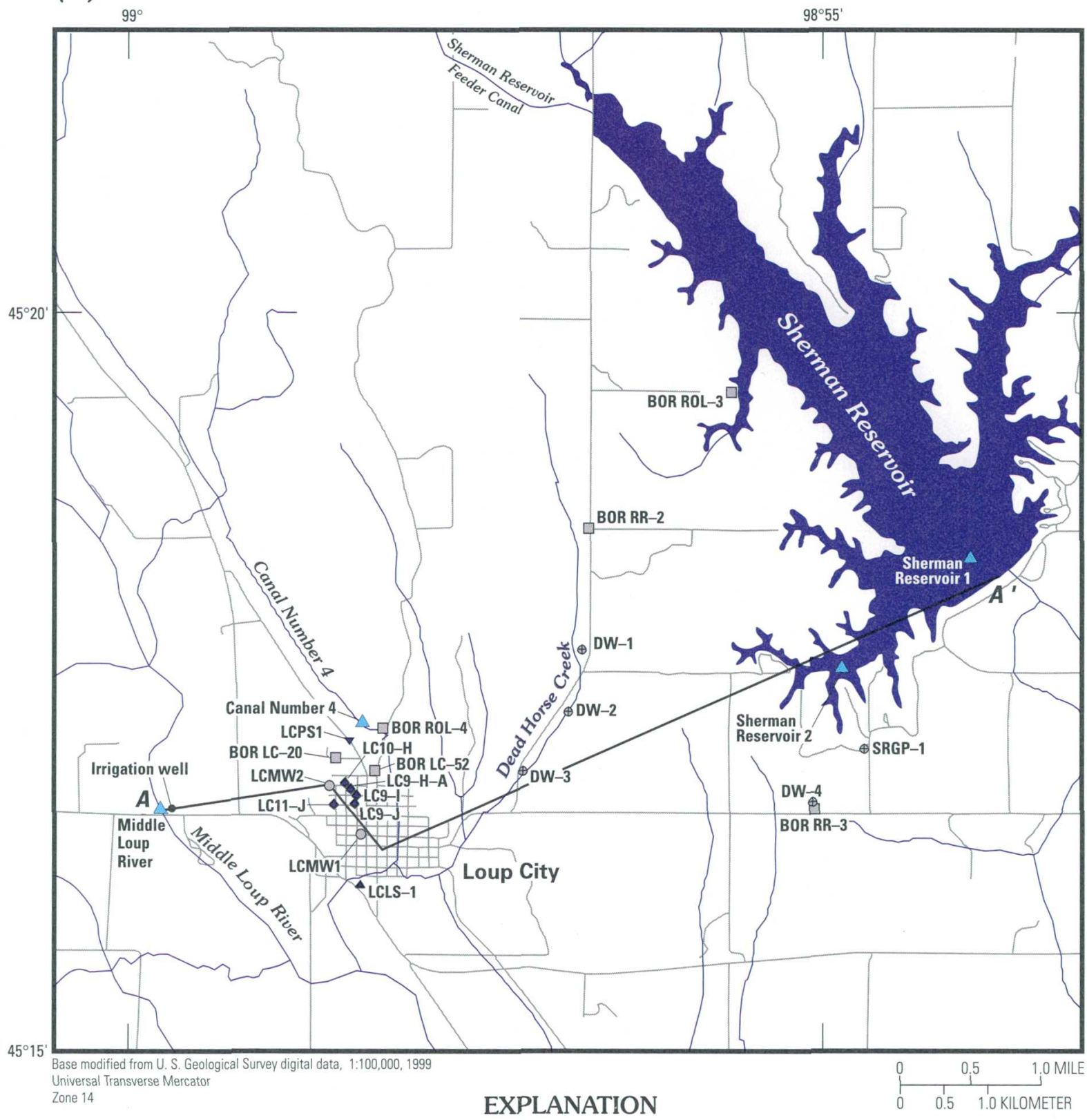

A $\quad A^{\prime}$ Trace of section shown in figure $2 B$

Sampling sites and identifiers

Canal Number 4 $\triangle$ Surface-water site DW- $3_{\oplus}$ Domestic well LC11-J Loup City observation well LCMW1○ Multi-level monitoring well

River, creek, canal or draw

- Well used for generation of cross section BOR RR-2 $\square$ Bureau of Reclamation observation well LCPS1 $\nabla$ Public-supply well LCLS-1 1 Sewer

Figure 2. (A) Locations of surface-water and ground-water sampling sites and (B) generalized geologic section in study area. 
(B)
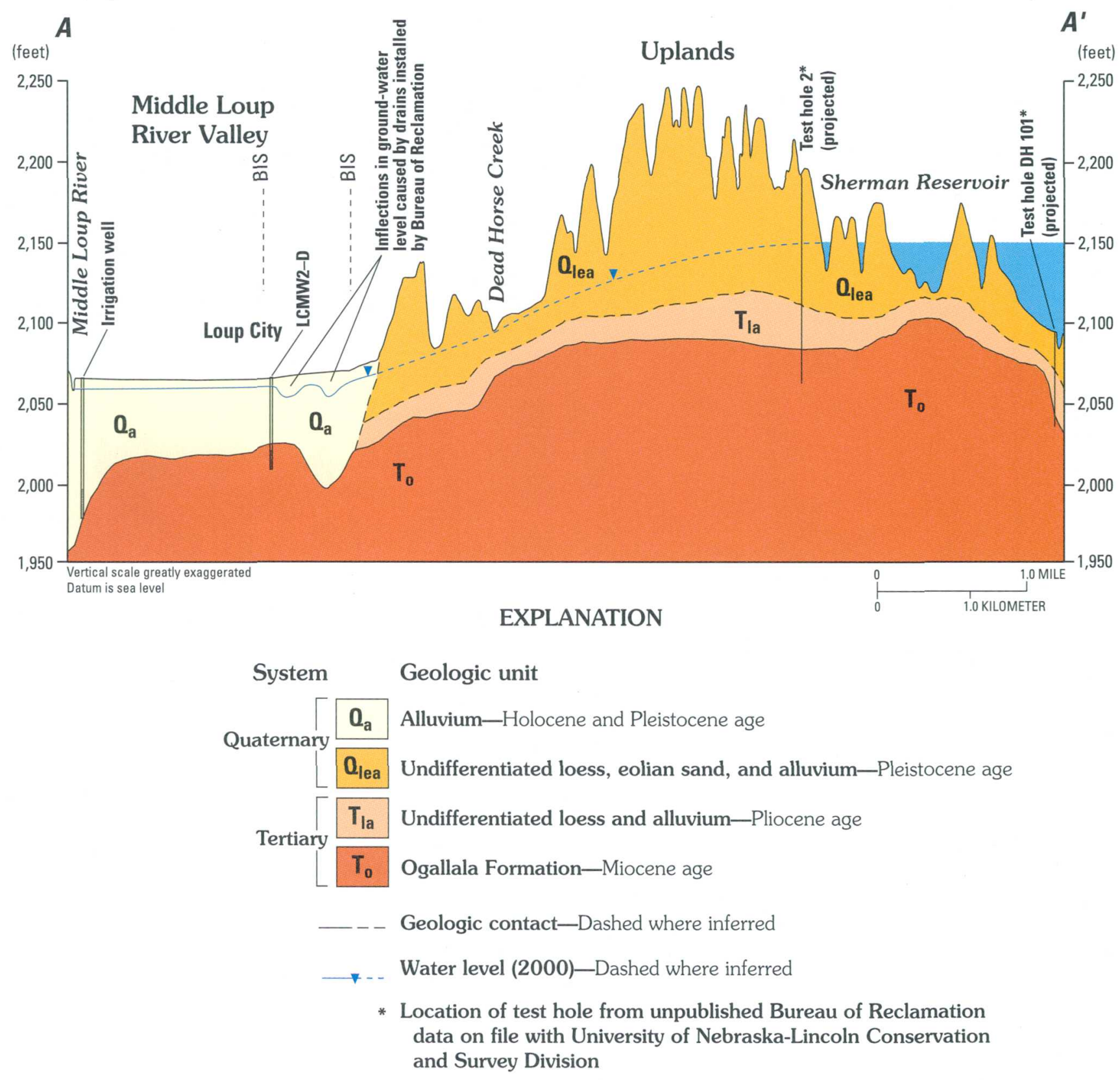

BIS Bend in section

Note: Depths to Pliocene-aged deposits in the uplands were derived from Bureau of Reclamation cores drilled prior to construction of Sherman Reservoir (unpublished data on file with University of Nebraska-Lincoln Conservation and Survey Division). Top of Ogallala Formation modified from Souders (2000).

Figure 2. (A) Locations of surface-water and ground-water sampling sites and (B) generalized geologic section in study area-Continued.

in this case is the Missouri River Basin. The next six digits represent the downstream order number.

The USGS ground-water site identification number is a 15 -character number that contains no blanks or alphabetical characters and generally is used as an internal control number. Although the site identification number was initially formed from a latitude and longitude, the number is an identifier and has no locational significance (Mathey, 1990, p. 2-10). Wells with the first 13 characters of the site identification 


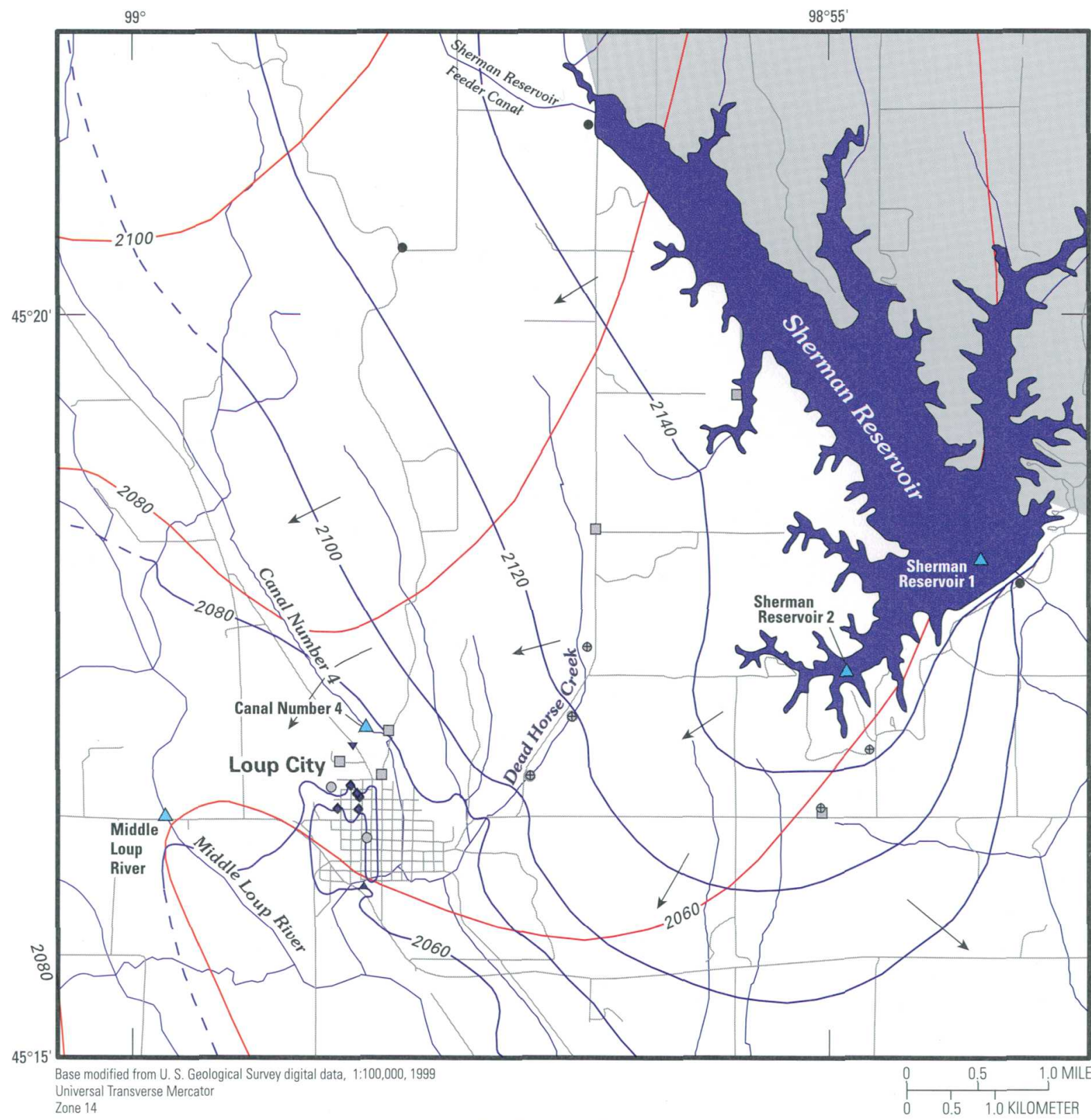

EXPLANATION

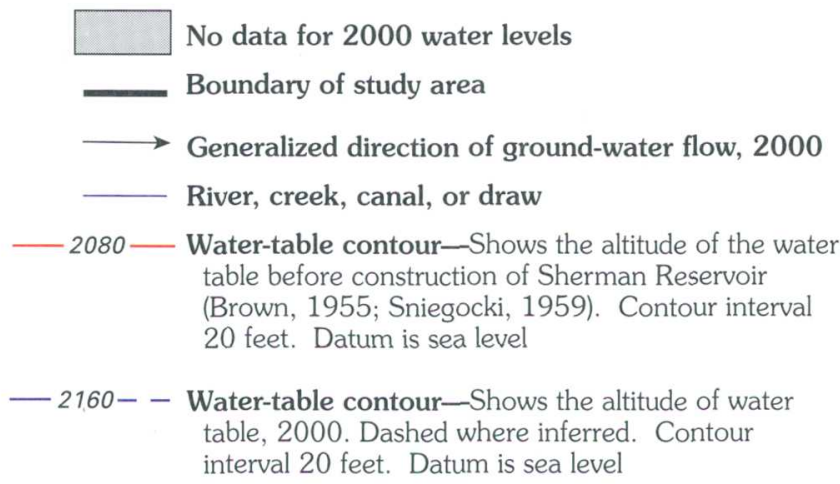
- Ground-water-level control point,
2000

Sampling sites

$\triangle$ Surface-water site

- Domestic well

- Loup City observation well

- Multi-level monitoring well

$\square$ Bureau of Reclamation observation well

v Public-supply well

^ Sewer

Figure 3. Configuration of water table in study area, before construction of Sherman Reservoir and during 2000. 
Table 2. Sites selected for surface-water sampling and construction data for wells sampled in study area, central Nebraska

[all Bureau of Reclamation (BOR) well depths are estimated from soundings made during study; USGS, U.S. Geological Survey; ID, identification number or identifier; fig., figure; D, deep; M, intermediate; S, shallow; --, not measured or not applicable; EWI, equal-width integrated sample; No., number; <, less than; SW, southwest; PSG, thought to be screened in the Pliocene-age sand and gravel deposits]

\begin{tabular}{|c|c|c|c|c|c|c|c|c|}
\hline $\begin{array}{l}\text { USGS } \\
\text { site ID }\end{array}$ & $\begin{array}{c}\text { Field ID } \\
\text { (fig. 2) }\end{array}$ & Local ID & Well type & $\begin{array}{l}\text { Depth of } \\
\text { sample or } \\
\text { well (feet } \\
\text { belowland } \\
\text { surface) }\end{array}$ & $\begin{array}{c}\text { Open } \\
\text { interval } \\
\text { (feet) }\end{array}$ & Aquifer & $\begin{array}{c}\text { Well } \\
\text { diame- } \\
\text { ter } \\
\text { (inches) }\end{array}$ & $\begin{array}{c}\text { Depth to } \\
\text { water } \\
\text { (feet } \\
\text { below } \\
\text { land } \\
\text { surface) }\end{array}$ \\
\hline \multicolumn{9}{|c|}{ Surface-water sites } \\
\hline 06779500 & Middle Loup River & Middle Loup River at Loup City & -- & EWI & -- & -- & -- & -- \\
\hline 06778450 & Canal 4 & Canal No. 4 at Loup City & -- & EWI & -- & -- & -- & - \\
\hline 06784195001 & Sherman Reservoir 1-D & Sherman Reservoir 1,200 feet & - & 45 & -- & -- & - & -- \\
\hline 06784195002 & Sherman Reservoir 1-M & Sherman Reservoir 1,200 feet & -- & 25 & -- & -. & -- & -- \\
\hline 06784195003 & Sherman Reservoir 1-S & Sherman Reservoir 1,200 feet & - & $<5$ & -- & -- & - & -- \\
\hline 06784190001 & Sherman Reservoir 2-D & Sherman Reservoir SW Branch & -- & 25 & : -- & -- & - & -- \\
\hline 06784190002 & Sherman Reservoir 2-M & Sherman Reservoir SW Branch & .. & 15 & -- & -. & -- & -- \\
\hline 06784190003 & Sherman Reservoir 2-S & Sherman Reservoir SW Branch & -- & $<5$ & -- & -- & -- & -- \\
\hline \multicolumn{9}{|c|}{ Ground-water sites } \\
\hline 411706098582201 & BOR LC-20 & 15N 14W 7CBDA1 & Observation & 25 & -- & Alluvial & 1.25 & 8.53 \\
\hline 411700098580201 & BOR LC-52 & $15 \mathrm{~N} 14 \mathrm{~W} 7 \mathrm{CA} 1$ & Observation & 30 & -- & PSG $^{1}$ & 1.25 & 16.64 \\
\hline 411912098544801 & BOR ROL-3 & 16N 14W34BBBB1 & Observation & 140 & -- & PSG & 1.25 & 42.08 \\
\hline 411728098574001 & BOR ROL -4 & $15 \mathrm{~N} 14 \mathrm{~W} 7 \mathrm{AB} 1$ & Observation & 90 & -- & PSG & 1.25 & 56.35 \\
\hline 411833098555701 & BOR RR-2 & $16 \mathrm{~N} \mathrm{14W33CCCC1}$ & Observation & 150 & -- & PSG & 1.25 & 66.59 \\
\hline 411649098541401 & BOR RR-3 & 15N 14W10DCCD1 & Observation & 140 & -- & PSG & 1.25 & 113.60 \\
\hline 411747098562001 & DW-1 & 15N 14W 5DDAA1 & Domestic & 202 & -- & Ogallala & 4.0 & -- \\
\hline 411723098562801 & DW-2 & $15 \mathrm{~N} 14 \mathrm{~W} 8 \mathrm{ADB} 1$ & Domestic & 184 & -- & Ogallala & 4.0 & -. \\
\hline 411701098565001 & DW-3 & 15N 14W 8DCBB1 & Domestic & 194 & $150-194$ & Ogallala & 4.0 & - \\
\hline 411648098542401 & DW-4 & 15N 14W10DCCA1 & Domestic & 200 & $180-200$ & Ogallala & 4.0 & - \\
\hline 411709098540101 & SRGP-1 & 15N 14W10ADDD1 & Domestic & 194 & $174-194$ & Ogallala & 4.0 & - \\
\hline 411656098581701 & LC10-H & $15 \mathrm{~N} 14 \mathrm{~W} 7 \mathrm{CDA} 1$ & Observation & 30 & $23-28$ & Alluvial & 2.0 & 5.12 \\
\hline 411648098582301 & LC11-J & $15 \mathrm{~N}$ 14W 7CCBD1 & Observation & 30 & $25-30$ & Alluvial & 2.0 & 5.86 \\
\hline 411654098581501 & LC9-H-A & $15 \mathrm{~N} 14 \mathrm{~W} 7 \mathrm{CDBD} 1$ & Observation & 20 & $15-20$ & Alluvial & 2.0 & 5.87 \\
\hline 411652098581201 & LC9-I & $15 \mathrm{~N} 14 \mathrm{~W} 7 \mathrm{CDCA1}$ & Observation & 24 & $15-20$ & Alluvial & 2.0 & 7.61 \\
\hline 411648098581301 & LC9-J & $15 \mathrm{~N} 14 \mathrm{~W} 7 \mathrm{CDCD} 1$ & Observation & 25 & $20-25$ & Alluvial & 2.0 & 6.74 \\
\hline 411637098581001 & LCMW I-D & 15N 14W18BADB1 & Monitoring & 55 & $50-55$ & Ogallala & 4.0 & 6.84 \\
\hline 411637098581002 & LCMW1-M & 15N 14W18BADB2 & Monitoring & 36 & $31-36$ & Alluvial & 4.0 & 7.01 \\
\hline 411637098581003 & LCMW1-S & 15N 14W18BADB3 & Monitoring & 23 & $18-23$ & Alluvial & 4.0 & 6.97 \\
\hline 411656098582701 & LCMW2-D & $15 \mathrm{~N} 14 \mathrm{~W} 7 \mathrm{CCAB} 1$ & Monitoring & 56 & $51-56$ & Ogallala & 4.0 & 5.26 \\
\hline 411656098582702 & LCMW2-M & $15 N$ 14W 7CCAB2 & Monitoring & 36 & $31-36$ & Alluvial & 4.0 & 6.06 \\
\hline 411656098582703 & LCMW2-S & $15 \mathrm{~N} 14 \mathrm{~W} 7 \mathrm{CCAB} 3$ & Monitoring & 23 & $18-23$ & Alluvial & 4.0 & 6.04 \\
\hline 411706098581001 & LCPS-1 & $15 \mathrm{~N} 14 \mathrm{~W} 7 \mathrm{CABB} 1$ & Public supply & 336 & $196-336$ & Ogallala & 16 & -- \\
\hline 411619098581001 & - LCLS-1 & 15N 14W18BDDCl & Sewer $^{2}$ & -- & -. & -. & -- & -- \\
\hline
\end{tabular}

${ }^{1}$ May be screened in loess deposits.

${ }^{2}$ Lift station with subterranean storm and sanitary sewage ports. 
number in common are distinguished by adding a sequential digit to the number. Sequential numbers are assigned by order of inventory such as 411637098581001 and 411637098581002.

The second method, field identifier, is associated with the location of the surface-water or monitoring-well site, the geographical name, or the owner or type. For surface-water sites, the geographical name was used-such as Middle Loup River and Canal 4. Because Sherman Reservoir is large, two sampling sites were selected on the reservoir-Sherman Reservoir 1 and Sherman Reservoir 2 . The number ' 1 ' represents the site located in the main pool of the reservoir, whereas the number ' 2 ' represents the site in an arm off of the main pool but toward Loup City.

For ground-water sites, field identification numbers assigned by BOR kept their original field identification number (such as BOR LC-20 and BOR LC-52). All domestic wells, except for the Nebraska Game and Parks well, were assigned DW to indicate domestic wells. The terminal numeric sequence for the domestic wells was assigned by order of inventory - DW-1 to DW-4. The remaining domestic well was assigned SRGP-1 because it is near Sherman Reservoir and is owned by the State of Nebraska Game and Parks Commission. Observation wells owned by Loup City were assigned a preceding LC and terminated with a number-letter sequence representing the nearest street intersection. Thus, LC9-J represented an observation well located in Loup City at the intersection of $9^{\text {th }}$ and J Streets. One observation well, LC9-H-A, was in an alley near the intersection of $9^{\text {th }}$ and $H$ Streets and was assigned the terminal letter 'A.' Loup City's public-supply well and sewer lift station were assigned LCPS-1 and LCLS-1, respectively.

The two multi-level monitoring-well sites that were installed for this study were assigned a field identification number similar to all other Loup City wells-LCMW1 and LCMW2. The field identification numbers started with LC to designate the owner, but MW was added to designate them as multi-level monitoring wells. Terminal designations for the sites were 1 or 2 to designate the site number and $S$ (shallow), $M$ (intermediate), or D (deep) to designate the depth. Thus, LCMW2-S was the shallowest multi-level monitoring well at the second site.

The third method, local identifier, is the official USGS location description. For surface-water sites,

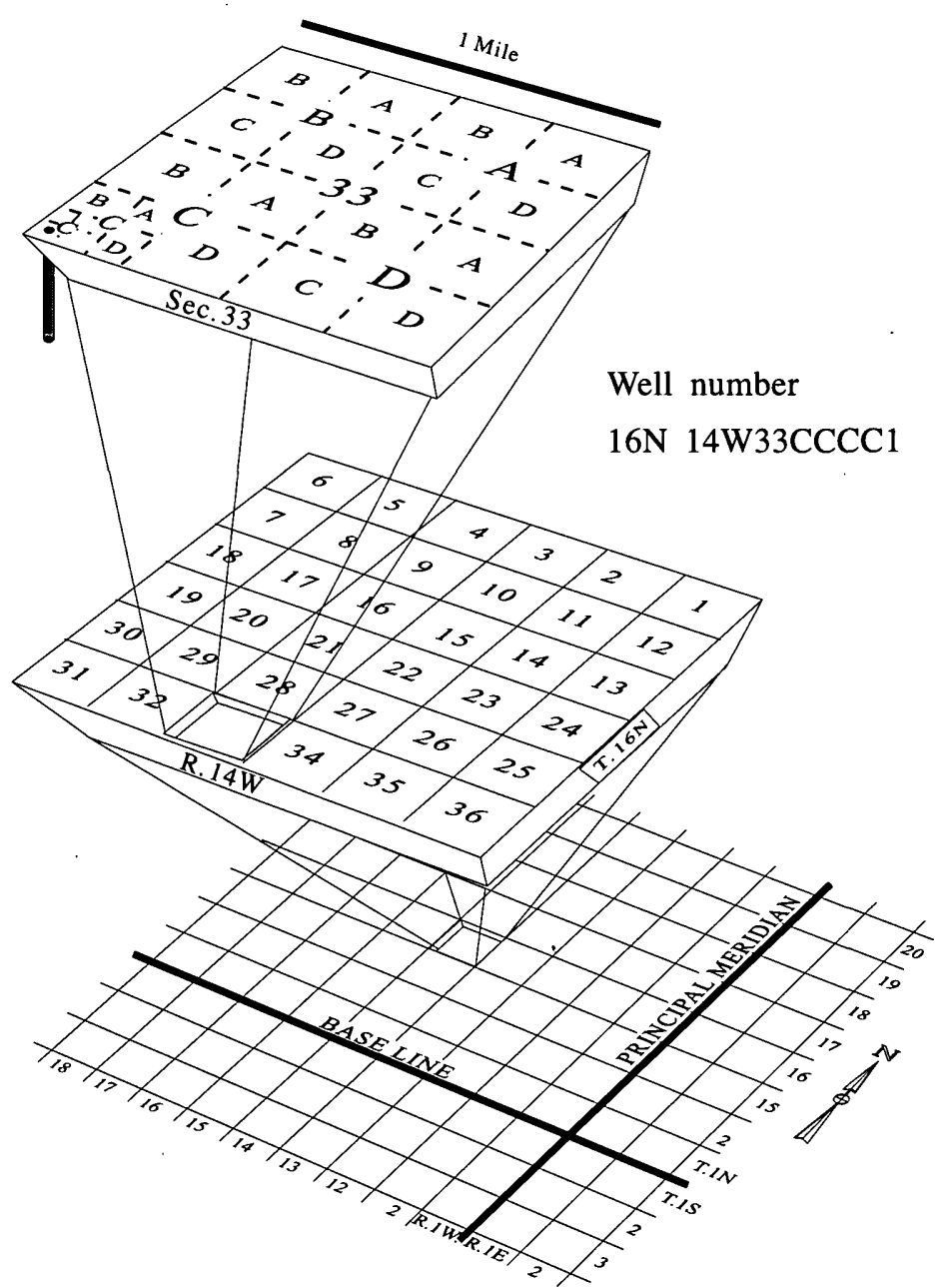

Figure 4. Well-numbering system.

this was the name of the site. For ground-water sites, it was based on the land subdivisions in the Bureau of Land Management's (BLM) survey of Nebraska (fig. 4). The number preceding $N$ (north) indicates the township or tier, the numeral preceding W (west) indicates the range, and the numbers preceding the terminal letters indicate the section in which the well is located. The terminal letters designated A, B, C, and $\mathrm{D}$, denote the quarter section, the quarter-quarter section, the quarter-quarter-quarter section, and the quarter-quarter-quarter-quarter section. The designation is given in a counterclockwise direction beginning with " $A$ " in the northeast corner of each subdivision. Each well also is assigned a terminal number " 1 " designating the order of inventory. Like the USGS site identification number, two or more wells are distinguished further by adding a sequential digit to the well number, assigned by order of inventory. 


\section{Sample Collection}

Surface-water samples from the Middle Loup River and Canal 4 were collected using equal-width increment sampling procedures as described by Wells and others (1990). The discharges for the Middle Loup River and Canal 4 were measured concurrently with sample collection. Water samples from Sherman Reservoir were collected from a boat using a submersible pump at the desired depth. All sample collections used standard USGS procedures as described by Wells and others (1990) and U.S. Geological Survey (1997 to present).

Ground-water samples were collected from the monitoring-well sites using standard USGS procedures as described by U.S. Geological Survey (1997 to present). A submersible pump was used to pump water through a flow-through chamber to monitor the physical properties (specific conductance, $\mathrm{pH}$, temperature, and dissolved oxygen concentration) prior to the collection of a sample. Water samples from domestic wells were collected using a hose connecting an outside spigot (that was independent of a pressure tank) to the flow-through chamber. Physical property measurements were read at 3-minute intervals and recorded after these readings stabilized within preset limitations or after at least three well volumes of water had been removed from the well. Some wells did not yield sufficient volumes of water or, in the case of the BOR observation wells, they were too narrow to allow collection of ground-water samples with a submersible pump. In these wells, disposable bailers were used to extract the required three casing volumes before the wells were sampled. In some cases, BOR observation wells, such as well LC-20, were bailed dry and then sampled the following day after ground-water levels had recovered. For these wells it was presumed that because the well was bailed dry, the water yielded by the well the following day represented the water in the aquifer.

Sampling for analyses of concentrations of chlorofluorocarbons (CFCs) (CFC-12, dichlorodifluoromethane, $\mathrm{CF}_{2} \mathrm{Cl}_{2}$; $\mathrm{CFC}-11$, trichlorofluoromethane, $\mathrm{CFCl}_{3}$; and $\mathrm{CFC}-113$, trichlorotrifluoroethane, $\mathrm{C}_{2} \mathrm{~F}_{3} \mathrm{Cl}_{3}$ ) in ground water requires special sampling techniques and equipment. This equipment was designed to ensure that the ground-water sample did not come in contact with the atmosphere, as described by Busenberg and Plummer (1992) and U.S. Geological Survey (1997 to present). This special equipment facilitates sealing water samples into borosilicate-glass ampoules prior to transport to the laboratory. Analyses for CFCs also require the collection of dissolved-gas samples in serum bottles, which are preserved on ice immediately following collection of the water sample. Dissolved-gas samples help define a recharge temperature that is used in calculating the ground-water age (Busenberg and Plummer, 1992).

\section{Sample Analysis}

Water samples from all sites were analyzed for physical properties and major ions (such as calcium, magnesium, sodium, potassium, sulfate, and chloride), nutrients, and selected isotopes-oxygen-18 $\left({ }^{18} \mathrm{O}\right)$, deuterium $\left({ }^{2} \mathrm{H}\right)$, and tritium $\left({ }^{3} \mathrm{H}\right)$. Samples from a subset of the sites (one of the domestic wells, all six of the multi-level monitoring wells, the single publicsupply well, as well as the Middle Loup River, and the intermediate depth at both Sherman Reservoir sampling sites) were analyzed for CFC and selected dissolved gases (argon, carbon dioxide, methane, nitrogen, and oxygen). Water samples collected for analyses of major ions and nutrient concentrations were sent to the USGS National Water-Quality Laboratory (NWQL) in Denver, Colorado, for analysis. Water samples collected for analysis of CFCs and concentrations of dissolved gases were sent to the USGS CFC Laboratory in Reston, Virginia. Water samples collected for analyses of ${ }^{18} \mathrm{O},{ }^{2} \mathrm{H}$, and ${ }^{3} \mathrm{H}$ were sent to the University of Waterloo (Ontario, Canada) and Purdue University (Lafayette, Indiana), respectively.

\section{Chlorofluorocarbons and Ground-Water Age Dating}

Previous studies using the CFC age-dating techniques have determined the age of recently (less than about 50 years) recharged ground water with an accuracy of plus-or-minus 1 to 3 years (Busenberg and Plummer, 1992; Plummer and Busenberg, 2000). The CFC age-dating technique is more precise, and analytical costs are less than other techniques, such as tritium or ${ }^{3} \mathrm{H} /{ }^{3} \mathrm{He}$ (helium), used for dating recent ground water. CFC ground-water ages also agree favorably with ages determined using other dating techniques, such as tritium, ${ }^{3} \mathrm{H} /{ }^{3} \mathrm{He}$, and krypton- 85 (Ekwurzel and others, 1994). However, because CFCs can and do degrade under certain conditions (such as 
anoxic conditions), overall accuracy of ground-water age dating can diminish.

CFC concentrations in the water samples are compared to calculated and measured values in the air (fig. 5). These comparisons then are used to determine a "modeled" or "apparent" age for the water. Modeled ages are provided because of the uncertainty involved in quantifying the actual ground-water flow rates. Ground-water age, when using CFC concentrations in water samples, are based on the minimum estimate of time that has elapsed since the newly recharged water has come into contact with the saturated zone and, thus, became isolated from the soil atmosphere (Szabo and others, 1996; Plummer and Busenberg, 2000). The age of the water also is based on the assumption of piston flow and does not account for mixing scenarios that can occur in wells with large open intervals or multiple producing fracture zones, or diffusion or dispersion resulting
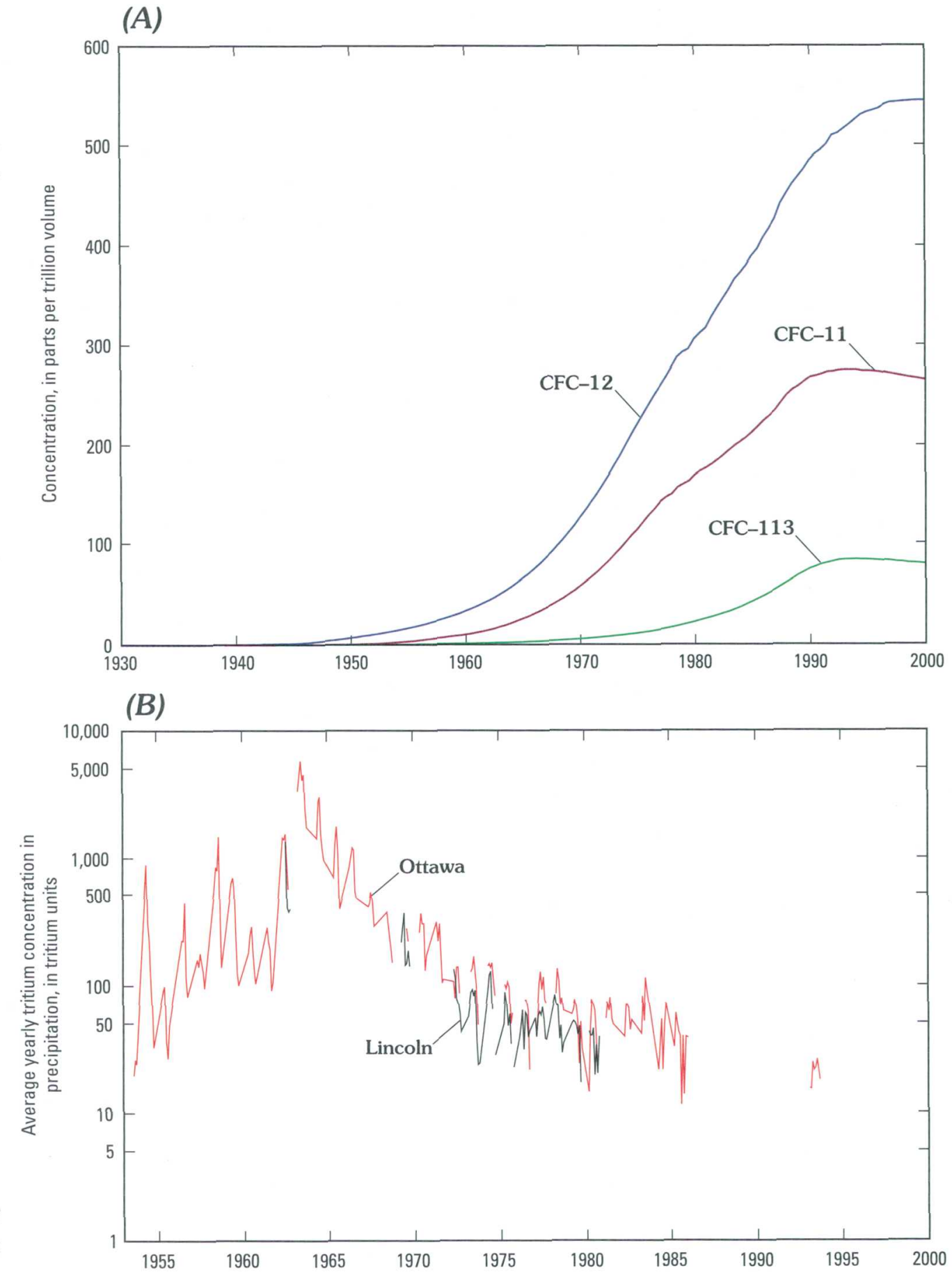

from ground-water flow and transport. Therefore, the results are referred to as "modeled" or "apparent" ages. For this report, all ages that were determined by CFC data are referred to as modeled. The assumption of piston flow is reasonable considering the open intervals of the wells are much shorter than the thickness of

Figure 5. (A) Atmospheric concentrations of chlorofluorocarbons CFC-11, CFC-12, and CFC-113 in North America air (modified from Plummer and Busenberg, 2000) and (B) tritium concentrations in precipitation from Ottawa, Ontario, Canada, and Lincoln, Nebraska (International Atomic Energy Agency, 2001).

the aquifer. Szabo and others (1996) report that the difference between the minimum traveltime at the top of the open interval and the maximum traveltime at the bottom of the open interval is most significant at depth where ground-water flow lines are closely spaced.

Near the water table the ground-water flow lines are 
not as closely spaced, and the small open intervals of the wells intersect fewer flow lines. Water that is determined to be of "modern" age refers to water with CFC concentrations that are within the possible range of modern air for the CFC concentration. For this report, "modern" refers to water whose modeled age is 0 to 10 years.

Uncertainties in CFC ages can arise from factors such as thickness of the unsaturated zone, mixture of young and old water, errors in estimating recharge temperature, degradation of CFCs (redox conditions from anoxic, sulfate-reducing, or methanogenic environments), dispersion of ground-water flow, and CFC contamination (Plummer and Busenberg, 2000). Unsaturated zone thicknesses that exceed $30 \mathrm{ft}$ cause lag-time errors. Cook and Solomon (1995) presented calculated lag times for CFC concentrations. They suggest that lag times from unsaturated zone thickness that is less than $30 \mathrm{ft}$ will be less than 2 years and, thus, can be ignored. Mixture of young and old water or errors in estimating recharge temperature can make the modeled age of the water appear either too young or too old. Errors in estimating recharge altitudes can cause the modeled age to appear too young or too old because CFC dissolves less at higher altitudes than at lower altitudes. However, recharge estimates of altitudes that are less than $300 \mathrm{ft}$ in error are not important (Plummer and Busenberg, 2000). Degradation of CFCs can cause the modeled age of the water to appear too old. Dispersion of ground-water flow can cause younger water (1975 to 1993) to appear too old or older water (older than 1975) to appear too young. Contamination of CFCs generally produces impossibly young water (water that has recharged in the future) or water that appears too young.

Because the previously mentioned processes can affect CFC concentrations, concentrations of CFCs from water samples were tested for sensitivity. Thickness of the unsaturated zone was not considered because none of the sites where CFC data were collected had water tables (where recharge occurred) more than $30 \mathrm{ft}$ below the land surface. In addition, dispersion of ground-water flow is not expected to have a significant effect on CFC concentrations (Plummer and Busenberg, 2000). Therefore, hydrodynamic dispersion was assumed to be negligible. However, the remaining processes were tested. Testing included reviewing mixing scenarios of binary water (old mixed with young) and testing CFC concentrations for piston, binary, or exponential flow character- istics. Degradation of CFCs was evaluated through analysis of redox, sulfate-reducing, and methanogenic conditions from physical-property, water-chemistry, and dissolved-gases data collected during the study. CFC contamination was evaluated by comparing CFC air-mixture concentrations with concentrations in water samples.

\section{Isotopes}

A brief overview of isotopes and their use related to the Loup City study is presented here. Much of the material and a comprehensive discussion of isotopes and their uses in hydrologic studies are summarized in Clark and Fritz (1997).

A number of isotopes, both stable and radioactive, are used in hydrologic studies and have been termed "environmental isotopes." For this study, these include the stable isotopes of water- ${ }^{18} \mathrm{O}$ and ${ }^{2} \mathrm{H}$-and the radioactive isotope of hydrogen- ${ }^{3} \mathrm{H}$. Generally speaking, stable isotopes typically are used to identify the source (origin) of the water or its dissolved constituents and any physical, chemical, and biological processes that may have affected the water since its origin. Hydrogen and oxygen are the naturally occurring stable isotopes of water and, therefore, are ideal tracers. Radioactive isotopes are used to determine the "age" of water, that is, when recharge water loses contact with the atmosphere.

\section{Oxygen-18 and Deuterium}

Stable isotopes are measured as the ratio of the two most abundant isotopic forms of the element. For oxygen, it is the ratio of ${ }^{18} \mathrm{O}$, with an abundance of 0.204 percent, to ${ }^{16} \mathrm{O}$ (oxygen- 16 , the more common form), with an abundance of 99.796 percent. Thus, the ${ }^{18} \mathrm{O} /{ }^{16} \mathrm{O}$ ratio is about 0.00204 . For hydrogen, it is the ratio of ${ }^{2} \mathrm{H}$ (deuterium, also written as "D"), with an abundance of 0.015 percent, to the more common form, ${ }^{1} \mathrm{H}$ (protium), with an abundance of 99.985 percent, giving a ${ }^{2} \mathrm{H} /{ }^{1} \mathrm{H}$ ratio of about 0.00015 .

Stable isotope concentrations are expressed as the difference between the measured ratio of the sample and the measured ratio of a reference standard. Isotope results are reported as parts per thousand (per mil) with respect to the standard using the ' $\delta$ ' (pronounced delta) notation expressed as:

$$
\delta_{\text {sample }}=\left(\frac{R_{\text {sample }}}{R_{\text {standard }}}-1\right) \cdot 1000,
$$


where $\quad \mathrm{R}_{\text {sample }}$ is the ratio of ${ }^{18} \mathrm{O} /{ }^{16} \mathrm{O}$ or ${ }^{2} \mathrm{H} /{ }^{1} \mathrm{H}$ in the sample and $R_{\text {standard }}$ is the ratio of the international standard for oxygen and hydrogen, Vienna Standard Mean Ocean Water (VSMOW).

When using the $\delta$ notation, seawater has a $\delta^{18} \mathrm{O}$ value of 0 per mil. Thus, water samples that have negative $\delta^{18} \mathrm{O}$ (and $\delta^{2} \mathrm{H}$ as well) values (such as is typical with precipitation or ground-water samples) are said to be depleted in ${ }^{18} \mathrm{O}$ relative to seawater. Water samples that have positive $\delta$ values are said to be enriched in ${ }^{18} \mathrm{O}$ relative to seawater. These terms also can be used to describe two isotope compositions relative to each other. For example, a precipitation sample that has a $\delta^{18} \mathrm{O}$ value of -25 per mil is said to be depleted relative to a precipitation sample with a $\delta{ }^{18} \mathrm{O}$ value of -11 per mil. Likewise, a ground-water sample with a $\delta^{18} \mathrm{O}$ value of -5 per mil is said to be enriched relative to a ground-water sample that has a $\delta^{18} \mathrm{O}$ value of -12 per mil. In the literature, the terms "heavy" and "light" also may be used interchangeably with enriched and depleted when referring to stable isotope $\delta^{18} \mathrm{O}$ and $\delta^{2} \mathrm{H}$ values. For example, a precipitation sample with a $\delta^{18} \mathrm{O}$ value of -25 per mil is said to be isotopically lighter (or simply light) when compared to a precipitation sample having a $\delta^{18} \mathrm{O}$ value of -8 per mil. A surface-water sample with a $\delta^{18} \mathrm{O}$ value of -5 per mil is considered isotopically heavier (heavy) when compared to a ground-water sample with a $\delta^{18} \mathrm{O}$ value of -10 per mil. A simple rule to follow with regard to the terminology is-the more negative the value...the 'lighter' or more 'depleted' it is; the more positive the value...the 'heavier' or more 'enriched' the sample is said to be.

A plot of $\delta^{18} \mathrm{O}$ versus $\delta^{2} \mathrm{H}$ can be used to determine probable groundwater sources (Craig, 1961). The $\delta^{18} \mathrm{O}$ and $\delta^{2} \mathrm{H}$ values of global precipitation generally plot close to a straight line, called the global meteoric water line (GMWL). The equation of this line is $\delta^{2} \mathrm{H}=8 \cdot \delta^{18} \mathrm{O}+10$. Local meteoric water lines (LMWLs), which have slightly different slopes and intercepts than the GMWL, result from differences in altitude, local climate, and distance from the moisture source. This study used LMWLs developed from data collected at two nearby National Atmospheric Deposition Project locations in Nebraska-Mead (Harvey, 2001) and North Platte (Harvey and Welker, 2000). If ground-water $\delta^{18} \mathrm{O}$ and $\delta^{2} \mathrm{H}$ values plot near the LMWL for the sampling area, the water likely is meteoric in origin, that is to say, derived from precipitation without subsequent modification. If they do not plot along this line, they have been affected by some physical or chemical process prior to recharge or during residence in the aquifer.

Once meteoric water is precipitated, a number of processes may alter the water's isotopic signature (the combined $\delta^{18} \mathrm{O}$ and $\delta^{2} \mathrm{H}$ values). The process most relevant to this study is evaporation. As water evaporates from an open surface (river, lake, or irrigated field), its signature moves away from the meteoric water line along a line having a slope of between 2 and about 5 (depending on the effect of humidity). This shift off the meteoric water line occurs because of the difference in the vapor pressures of $\mathrm{H}_{2}{ }^{18} \mathrm{O}$ and ${ }^{2} \mathrm{HHO}$, which imparts disproportional enrichments in the water phase during evaporation (Clark and Fritz, 1997). For a given type of water, the greater the degree of evaporation, the farther from the meteoric water line the resulting signature will be. Rivers and lakes typically undergo greater evaporation than ground water and generally plot off the meteoric water line along an evaporation line (fig. 6).

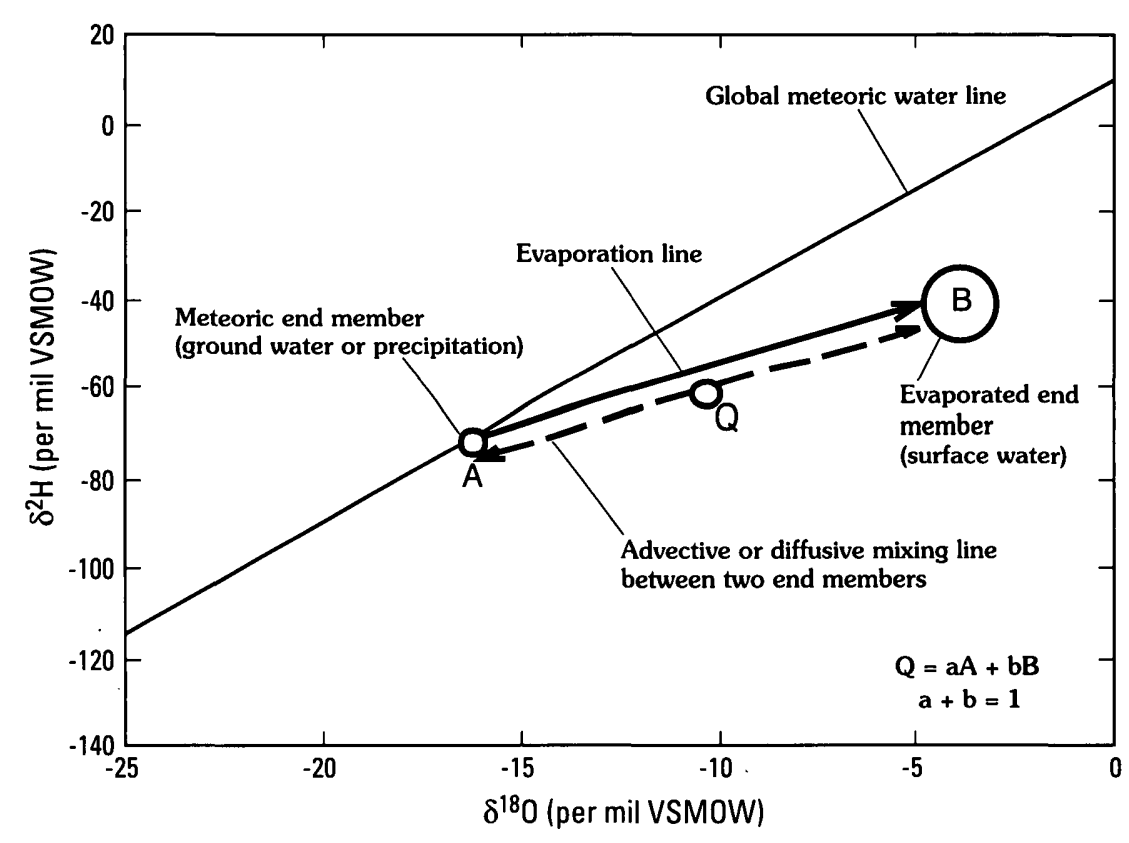

Figure 6. Mixing of ground-water source with an evaporated water source, such as a reservoir (VSMOW = Vienna Standard Mean Oceanic Water; $A$ is meteoric end member; $B$ is evaporated end member, and $Q$ is sum of $A$ and $B$, where $a=$ percent of $A$, $b=$ percent of $B$, and $a+b=1$ ). 
If a sample of ground water plots off the meteoric water line, along an evaporation line, one of two conclusions can be reached: (1) the sample has been affected by evaporation prior to recharge (water reaching the saturated zone), or (2) the sample represents a mixture of two "end member" types of water-one of meteoric origin (plotting on the water line) and one having undergone evaporation (a river or lake, for example, plotting off the line) (fig. 6). Ground water having undergone mixing typically will plot somewhere between the two end members. The degree and ratio of mixing determines the proximity of the ground-water sample to an end member. The closer the ground-water sample is to a particular end member, the larger the ratio of the end member in the groundwater sample.

\section{Tritium}

Tritium $\left({ }^{3} \mathrm{H}\right)$ is the naturally occurring, short-lived radioactive isotope of hydrogen and is produced in the upper atmosphere by the reaction of cosmic neutrons (n) with ${ }^{14} \mathrm{~N}$ (Faure, 1986):

$$
{ }^{14} \mathrm{~N}+n \rightarrow{ }^{3} \mathrm{H}+{ }^{12} \mathrm{C},
$$

where ${ }^{14} \mathrm{~N}$ is the isotope nitrogen- 14 and ${ }^{12} \mathrm{C}$ is the isotope carbon- 12 .

Tritium combines with oxygen to form tritiated water $\left({ }^{3} \mathrm{HHO}\right)$, which is dispersed throughout the hydrosphere. Tritium's half-life, 4,500 days (12.32 years) (Lucas and Unterweger, 2000), allows it to be used as a dating tool for relatively young water (less than 50 years) (Mann and others, 1982). The natural background activity of ${ }^{3} \mathrm{H}$ in precipitation prior to 1952 was about 1 to 10 tritium units (TU) (Davis and DeWiest, 1966). Beginning in 1952, large amounts of ${ }^{3} \mathrm{H}$ were added to this natural background value from aboveground testing of thermonuclear weapons. At the maximum in 1963, the quantity of human-generated tritium produced was 100 to 1,000 times greater than that of natural ${ }^{3} \mathrm{H}$ (Fontes, 1980).

Tritium concentrations in precipitation have been monitored at numerous locations throughout North America since the early 1950 s. The nearest location to the study area is Lincoln, Nebraska; however, Ottawa, Ontario, Canada (not shown in figures) has a more complete record. Tritium concentrations were recorded in precipitation samples in Lincoln from 1962 to 1986, and at Ottawa from 1953 to the present (fig. $5 B$ ). Figure $5 B$ shows a plot of the average yearly ${ }^{3} \mathrm{H}$ activity in precipitation at both of these sites. The major increase in ${ }^{3} \mathrm{H}$ concentration in 1963 reflects the peak of aboveground thermonuclear testing. Since that time, ${ }^{3} \mathrm{H}$ concentrations in Ottawa precipitation have decreased gradually to a current value of about $20 \mathrm{TU}$ (International Atomic Energy Agency, 1992). Precipitation in east-central Nebraska has similar values ranging from 10 to $30 \mathrm{TU}$ (unpublished precipitation data from this study and others that currently are being conducted by Dr. F. Edwin Harvey, University of Nebraska-Lincoln, School of Natural Resource Sciences and Conservation and Survey Division).

The significant difference in ${ }^{3} \mathrm{H}$ concentrations between precipitation before 1952 and precipitation after 1952, and the significant increase in ${ }^{3} \mathrm{H}$ concentrations in 1963 precipitation allow ${ }^{3} \mathrm{H}$ to be used as a natural tracer. Tritium has been used to determine ground-water age and flow velocities (von Buttlar, 1959; Egboka and others, 1983), dispersion in the ground-water zone (Atakan, 1972; Robertson and Cherry, 1989), diffusion in the ground-water zone (Foster, 1975), and ground-water recharge (Allison and Hughes, 1975; Larson and others, 1987; Daniels and others, 1989).

In this study, ${ }^{3} \mathrm{H}$ was used to determine the age of surface-water and ground-water samples. Generally, water samples containing measurable ${ }^{3} \mathrm{H}$ concentrations likely have been recharged since the early 1950 s. Water samples that do not have detectable concentrations of ${ }^{3} \mathrm{H}$ likely recharged prior to the 1950 s.

\section{Quality Assurance and Quality Control}

To ensure that each sample collected represented actual constituent concentrations, quality-assurance (QA) and quality-control (QC) measures were instituted. Consequently, six replicate and blank samples, which represent about 10 percent of the total samples, were collected during the study. All QA/QC samples were collected concurrently, processed, and shipped with the regular samples. In addition, samples for major-ion analysis were reanalyzed if their anion and cation concentrations did not balance within 5 percent of each other.

\section{Data-Analysis Procedures}

Data-analysis procedures included general statistical analyses and the generation of maps, box plots, trilinear diagrams, scatter plots, and time-series plots. This report contains only selected maps and plots 
appropriate for the discussion. The generalized geologic section (fig. $2 B$ ) was created using a compilation of available data. The contact of the Ogallala Formation was developed from nearby BOR core analyses used for designing Sherman Reservoir Dam, and the contours from Sounders (2000). The contacts of the Pliocene-aged sediment are inferred. No data were available to map the contact accurately, but Souders (2000) reports its presence. The water table before Sherman Reservoir construction shown in figure 3 was generated using historical data from Brown (1955) and Sniegocki (1959). The 2000 water table (fig. 3) was constructed from data collected during this study. The water levels shown in figure 2 were generated from the 2000 water-table map (fig. 3).

For water-quality analyses, the generation of trilinear diagrams required a concentration of bicarbonate from the water samples. Bicarbonate concentrations were calculated by dividing carbonate values (estimated from the acid-neutralizing capacity) by 0.8202 as described by Hem (1985). Some data were analyzed and described in terms of statistical quartiles (percentiles)-data values less than 25, 50, or 75 percent of the sample observations. Percentiles are more descriptive than minimum and maximum because they more accurately represent the distribution of the data.

Nonparametric statistical analysis of the data was performed to determine variations between data sets. Nonparametric statistical methods rely on the conversion of data to ranked values and do not require that the data be distributed normally (Dowdy and Wearden, 1991).

Data were grouped into appropriate subgroups, and each "censored datum" was assigned a value equal to one-half the reporting limit. Censored data have values less than the reporting limit of the analytical procedure. A value of one-half the reporting limit assures that the censored data remain smaller than the smallest number greater than the reporting limit. Because the tests performed are nonparametric and compare two independent populations by ranking the data, assigning a minimum value to the censored data does not affect the test results (Helsel and Hirsch, 1992).

The Mann-Whitney rank-sum test (Helsel and Hirsch, 1992) was used to determine if median chemical concentrations were significantly different between independent populations, such as sulfate concentrations from ground-water samples at Loup City compared with sulfate concentrations in ground-water samples from the domestic wells. All statistical analyses used a confidence level of 95 percent $(\alpha=0.05)$. A confidence level is the probability that the test statistic generated for the test accurately defines the populations being tested. The p-value associated with this particular test is the probability of getting a test statistic equal to, or more extreme than, the value computed from the data when the null hypothesis (difference in the medians of the populations is zero) is true. If the p-value was less than or equal to 0.05 , the null hypothesis was rejected, and it was assumed that a significant difference existed between the two populations. If the p-value was greater than 0.05 , the null hypothesis was accepted, and a significant difference between the two populations could not be concluded.

\section{RESULTS OF DATA ANALYSES}

This section presents the results of the analyses of the physical and chemical data collected in the study area. Analyses of the physical characteristics were limited primarily to hydrographs and water-table configuration maps. Analyses of the chemical characteristics are presented in graphs and tables. This section also describes the analyses of the ground-water ages and the analysis of the isotope data.

\section{Physical Characteristics}

Although ground-water-level data collected before Sherman Reservoir construction in the Loup City area are limited, analysis of historical water-level data collected from BOR observation wells shows that ground-water levels between Loup City and Sherman Reservoir rose as much as $85 \mathrm{ft}$ since the completion of Sherman Reservoir (fig. 7). A comparison of the water table before Sherman Reservoir construction with the 2000 water table (fig. 3) shows that the ground-water-flow direction between Sherman Reservoir and Loup City has changed. This indicates that Sherman Reservoir is losing water to the ground-water system and locally affecting ground-water levels in wells between Sherman Reservoir and Loup City.

Following the completion of the multi-level monitoring wells, ground water in wells open to the Ogallala aquifer (wells LCMW1-D and LCMW2-D) and directly beneath the alluvial aquifer rose about $30 \mathrm{ft}$ above the top of the contact of the alluvial and Ogal- 


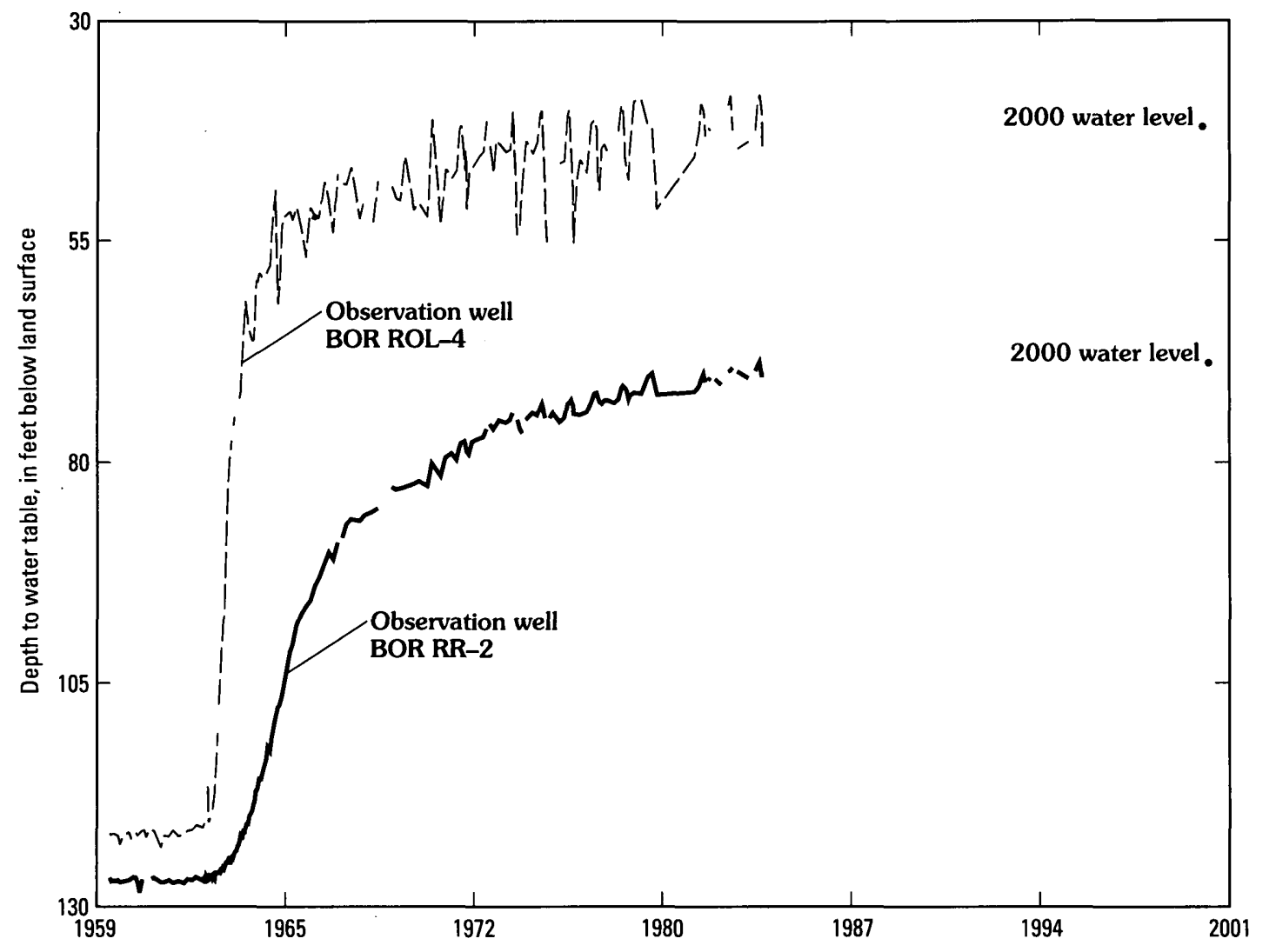

Figure 7. Depth to water table in selected Bureau of Reclamation observation wells in study area. Location of observation wells shown in figure 2.

lala aquifers. The cause of the hydrostatic pressure has not been determined, but it is likely the result of both hydraulic pressure placed on the ground-water reservoir both by locally confined conditions and by Sherman Reservoir. Sniegocki (1959) reported that ground water in the study area is under both confined and unconfined conditions. Ground water likely is under locally confined conditions in the uplands east of Loup City. However, during this study, the presence of confined or unconfined conditions was not determined for ground water in the upland areas. With respect to the hydrostatic pressure exerted by Sherman Reservoir, the volume of water in Sherman Reservoir creates a tremendous downward force on the groundwater system, which, in turn, must be distributed elsewhere in the system. Both of these conditions could account for the hydrostatic pressure that was evident in the two monitoring wells.

In Loup City, measured ground-water levels between the shallow and deep monitoring wells and the intermediate-depth and the deep monitoring wells showed a slight upward ground-water head difference of about $0.20 \mathrm{ft}$. Alone, this small upward head differ- ence beneath Loup City does not identify the pressure from the reservoir as the cause of the higher groundwater levels. However, the mound development and the increased lateral hydraulic gradient from the reservoir to the city make it appear likely that those conditions may have increased the upward head difference after reservoir construction.

\section{Chemical Characteristics}

With some exceptions, temporal variations in specific-conductance measurements were fairly consistent (within 10 percent) between water samples collected in March/April and July (table 3). Specific conductance of water samples from surface-water sites typically was within 5 percent from the March/April sample to the July sample; whereas specific conductance in ground-water samples typically was within 20 percent. The specific conductance in water samples from one well (LC9-J) decreased about 46 percent between March/April and July. No reason was determined for the large reduction in specific conductance at this site; however, the July measurement 
Table 3. Results of measurements of physical properties in surface and ground water in study area, central Nebraska, 2000

[ID, identifier; fig., figure; SC, specific conductance in microsiemens per centimeter at 25 degrees Celsius; $\mathrm{pH}$, in standard units; $\mathrm{T}$, water temperature in degrees Celsius; DO, dissolved oxygen in milligrams per liter; SW, surface water; --, not measured; Alluvium, alluvial deposits; Ogallala, Ogallala Formation]

\begin{tabular}{|c|c|c|c|c|c|c|c|}
\hline $\begin{array}{l}\text { Field ID } \\
\text { (fig. 2) }\end{array}$ & Date & Time & SC & pH & $\mathbf{T}$ & DO & Source \\
\hline \multicolumn{8}{|c|}{ Surface-water sites } \\
\hline \multirow{2}{*}{ Middle Loup River } & $3 / 30 / 2000$ & 1630 & 217 & 8.2 & 15.0 & 9.1 & SW \\
\hline & $7 / 17 / 2000$ & 0910 & 252 & 8.4 & 21.5 & 8.1 & \\
\hline Canal $4^{1}$ & $7 / 20 / 2000$ & 1445 & 204 & 9.0 & -- & 8.8 & SW \\
\hline \multirow[t]{2}{*}{ Sherman Reservoir 1-D } & $3 / 30 / 2000$ & 1220 & 211 & 8.0 & 7.0 & 8.9 & SW \\
\hline & $7 / 19 / 2000$ & 1415 & 233 & 7.4 & 22.0 & .1 & \\
\hline \multirow[t]{2}{*}{ Sherman Reservoir 1-M } & $3 / 30 / 2000$ & 1230 & 210 & 8.0 & 8.0 & 9.8 & SW \\
\hline & $7 / 19 / 2000$ & 1520 & 220 & 8.3 & 25.0 & 5.4 & \\
\hline \multirow{2}{*}{ Sherman Reservoir 1-S } & $3 / 30 / 2000$ & 1240 & 210 & 8.0 & 8.5 & 10.1 & SW \\
\hline & $7 / 19 / 2000$ & 1415 & 221 & 8.3 & 25.0 & 6.1 & \\
\hline \multirow[t]{2}{*}{ Sherman Reservoir 2-D } & $3 / 30 / 2000$ & 1350 & 211 & 7.8 & 7.5 & 9.2 & SW \\
\hline & $7 / 19 / 2000$ & 1550 & 219 & 8.6 & 25.0 & 6.1 & \\
\hline \multirow[t]{2}{*}{ Sherman Reservoir 2-M } & $3 / 30 / 2000$ & 1400 & 211 & 8.0 & 8.0 & 9.9 & SW \\
\hline & $7 / 19 / 2000$ & 1610 & 220 & 8.6 & 25.0 & 6.1 & \\
\hline \multirow[t]{2}{*}{ Sherman Reservoir 2-S } & $3 / 30 / 2000$ & 1410 & 211 & 8.0 & 8.5 & 9.8 & SW \\
\hline & $7 / 19 / 2000$ & 1610 & 218 & 8.6 & 25.0 & 7.3 & \\
\hline \multicolumn{8}{|c|}{ Ground-water sites } \\
\hline BOR LC $-20^{2}$ & $3 / 31 / 2000$ & 1200 & 1,130 & 7.2 & 10.5 & -- & Alluvium \\
\hline \multirow[t]{2}{*}{ BOR LC-52 } & $4 / 04 / 2000$ & 1230 & 660 & 7.3 & 12.5 & -- & Ogallala \\
\hline & $7 / 18 / 2000$ & 1520 & 677 & 7.3 & -- & -- & \\
\hline \multirow[t]{2}{*}{ BOR ROL-3 } & $4 / 05 / 2000$ & 1000 & 253 & 7.1 & 11.5 & -- & Ogallala \\
\hline & $7 / 19 / 2000$ & 1050 & 297 & 7.4 & 18.5 & -- & \\
\hline \multirow[t]{2}{*}{ BOR ROL -4} & $4 / 05 / 2000$ & 1430 & 676 & 7.4 & 12.0 & -- & Ogallala \\
\hline & $7 / 26 / 2000$ & 0730 & 579 & 7.3 & 15.0 & -. & \\
\hline \multirow[t]{2}{*}{ BOR RR-2 } & $4 / 05 / 2000$ & 1100 & 540 & 9.6 & 13.0 & -- & Ogallala \\
\hline & $7 / 19 / 2000$ & 0850 & 438 & 8.3 & $-\cdot$ & -- & \\
\hline BOR RR $-3^{2}$ & $4 / 05 / 2000$ & 1215 & 119 & 9.0 & 12.0 & -- & Ogallala \\
\hline \multirow[t]{2}{*}{ DW-1 } & $4 / 05 / 2000$ & 1600 & 512 & 7.2 & 13.0 & 8.9 & Ogallala \\
\hline & $7 / 20 / 2000$ & 1050 & 513 & 7.5 & 13.5 & 9.1 & \\
\hline \multirow[t]{2}{*}{ DW-2 } & $4 / 05 / 2000$ & 1645 & 508 & 7.2 & 11.5 & 11.3 & Ogallala \\
\hline & $7 / 20 / 2000$ & 1230 & 485 & 7.6 & 12.5 & 10.1 & \\
\hline \multirow[t]{2}{*}{ DW-3 } & $4 / 06 / 2000$ & 09:00 & 548 & 7.1 & 12.5 & 8.4 & Ogallala \\
\hline & $7 / 20 / 2000$ & 1340 & 527 & 7.5 & 13.0 & 8.8 & \\
\hline \multirow[t]{2}{*}{ DW-4 } & $4 / 06 / 2000$ & 0945 & 531 & 7.1 & 12.0 & 9.1 & Ogallala \\
\hline & $7 / 20 / 2000$ & 0800 & 438 & 7.5 & 15.0 & 9.0 & \\
\hline \multirow[t]{2}{*}{ LC10-H } & $4 / 04 / 2000$ & 1330 & 592 & 7.3 & 11.5 & -- & Alluvium \\
\hline & $7 / 21 / 2000$ & 1340 & 546 & 7.5 & 20.0 & -- & \\
\hline
\end{tabular}


Table 3. Results of measurements of physical properties in surface and ground water in study area, central Nebraska, 2000-Continued

\begin{tabular}{|c|c|c|c|c|c|c|c|}
\hline $\begin{array}{l}\text { Field ID } \\
\text { (fig. 2) }\end{array}$ & Date & Time & SC & $\mathbf{p H}$ & $\mathbf{T}$ & DO & Source \\
\hline \multicolumn{8}{|c|}{ Ground-water sites-Continued } \\
\hline \multirow[t]{2}{*}{ LC11-J } & $3 / 31 / 2000$ & 0835 & 621 & 7.2 & 12.5 & 0.2 & Alluvium \\
\hline & $7 / 21 / 2000$ & 0800 & 634 & 7.3 & 13.0 & .2 & \\
\hline \multirow[t]{2}{*}{ LC9-H-A } & $3 / 31 / 2000$ & 1030 & 550 & 7.2 & 13.0 & 3.0 & Alluvium \\
\hline & $7 / 21 / 2000$ & 1220 & 550 & 7.2 & -13.5 & 2.3 & \\
\hline LC9-I ${ }^{2}$ & $3 / 31 / 2000$ & 1330 & 565 & 7.0 & 13.0 & -- & Alluvium \\
\hline \multirow[t]{2}{*}{ LC9-J } & $3 / 31 / 2000$ & 1235 & 835 & 7.1 & 13.0 & -- & Alluvium \\
\hline & $7 / 21 / 2000$ & 1300 & 445 & 7.4 & 13.5 & -- & \\
\hline \multirow[t]{2}{*}{ LCLS-1 } & $4 / 06 / 2000$ & 1030 & 1,580 & 7.4 & 11.0 & 5.5 & Alluvium \\
\hline & $7 / 24 / 2000$ & 1420 & 1,220 & 7.5 & 19.0 & 2.8 & \\
\hline \multirow[t]{2}{*}{ LCMW 1-D } & $3 / 28 / 2000$ & 1240 & 549 & 7.4 & 13.5 & 5.6 & Ogallala \\
\hline & $7 / 24 / 2000$ & 1210 & 535 & 7.2 & 14.5 & 7.4 & \\
\hline \multirow[t]{2}{*}{ LCMW1-M } & $3 / 28 / 2000$ & 1525 & 549 & 7.4 & 14.0 & 3.4 & Alluvium \\
\hline & $7 / 24 / 2000$ & 1250 & 542 & 7.3 & 14.0 & 6.0 & \\
\hline \multirow[t]{2}{*}{ LCMW1-S } & $3 / 28 / 2000$ & 1615 & 570 & 7.4 & 13.5 & .2 & Alluvium \\
\hline & $7 / 24 / 2000$ & 1330 & 567 & 7.2 & 14.0 & .2 & \\
\hline \multirow[t]{2}{*}{ LCMW2-D } & $3 / 29 / 2000$ & 0925 & 577 & 7.1 & 12.5 & 5.6 & Ogallala \\
\hline & $7 / 24 / 2000$ & 0850 & 576 & 7.2 & 13.5 & 5.6 & \\
\hline \multirow[t]{2}{*}{ LCMW2-M } & $3 / 29 / 2000$ & 1040 & 615 & 7.2 & 12.5 & 3.1 & Alluvium \\
\hline & $7 / 24 / 2000$ & 0940 & 604 & 7.3 & 13.5 & .2 & \\
\hline \multirow[t]{2}{*}{ LCMW2-S } & $3 / 29 / 2000$ & 1155 & 663 & 7.3 & 13.0 & 2.2 & Alluvium \\
\hline & $7 / 24 / 2000$ & 1020 & 638 & 7.5 & 13.0 & .2 & \\
\hline \multirow[t]{2}{*}{ LCPS-1 } & $3 / 29 / 2000$ & 1450 & 590 & 7.3 & 12.5 & 5.6 & Ogallala \\
\hline & $7 / 21 / 2000$ & 1450 & 592 & 7.2 & 15.0 & 5.2 & \\
\hline \multirow[t]{2}{*}{ SRGP-1 } & $3 / 30 / 2000$ & 0900 & 314 & 7.4 & 13.0 & .5 & Ogallala \\
\hline & $7 / 20 / 2000$ & 0930 & 323 & 7.7 & 14.5 & .2 & \\
\hline
\end{tabular}

${ }^{1}$ Canal 4 was dry during March/April 2000 sample period.

${ }^{2}$ Not sampled in July 2000.

$(445 \mu \mathrm{S} / \mathrm{cm})$ is closer to measurements in water from the other wells in Loup City. pH values varied little in water samples from surface-water and ground-water sites. Most $\mathrm{pH}$ measurements in samples from these sites were within 1.0 standard unit between March/ April and July. For the most part, the temperature of the ground water does not change substantially through the year. Temperatures of ground water from samples collected in July typically stayed within 10 percent of those collected in March/April. Some exceptions are a 61-percent change in temperature in water from well BOR ROL-3 $\left(11.5\right.$ to $\left.18.5^{\circ} \mathrm{C}\right)$ and a 74-percent change in water from well LC10-H $\left(11.5\right.$ to $20^{\circ} \mathrm{C}$ ). No determinations were made as to why the water temperatures at these two sites changed so much.

Most of the water-quality constituents varied among the three sources sampled (fig. 8). The largest difference among the three sources, with respect to physical properties, was in concentrations of dissolved oxygen. Dissolved-oxygen concentrations in groundwater samples from the alluvial aquifer were much smaller and significantly different $(p$-value $=0.00)$ than those from surface water or from the Ogallala 
aquifer. Water samples from observation well LC11-J and multilevel monitoring wells LCMW1-S, LCMW2-M, and LCMW2-S had at least one dissolved-oxygen measurement less than $0.5 \mathrm{mg} / \mathrm{L}$ (table 3). For the surface-water sites and Ogallala aquifer, only water from Sherman Reservoir 1-D and domestic well SRGP-1 had at least one dissolved-oxygen concentration less than $0.5 \mathrm{mg} / \mathrm{L}$. Dissolvedoxygen concentrations in samples from the surfacewater sites and the Ogallala aquifer were not significantly different ( $\mathrm{p}$-value $=0.38) \cdot \mathrm{pH}$ of water samples varied significantly between the surface-water and ground-water samples (surface water and alluvial aquifer, $p$-value $=0.00$; surface water and Ogallala aquifer, $\mathrm{p}$-value $=0.00$ ) but did not vary significantly between samples collected from the alluvial and Ogallala aquifers ( $\mathrm{p}$-value $=0.53$ ).

Minimum, maximum, and quartile concentrations were computed for the water-quality analyses from the three sources (table 4). Median concentrations for constituents in water samples from the alluvial and Ogallala monitoring wells were similar. However, the median concentration of sulfate in water samples from the alluvial aquifer $(15 \mathrm{mg} / \mathrm{L})$ was nearly twice the median concentration of sulfate measured in water samples from the Ogallala aquifer $(8.0 \mathrm{mg} / \mathrm{L})$. Concentrations of hydrogen sulfide $\left(\mathrm{H}_{2} \mathrm{~S}\right)$ coupled with low concentrations of dissolved oxygen typically are found in areas that are at the end of ground-water flow paths (Domenico and Schwartz, 1990). Although not measured directly, $\mathrm{H}_{2} \mathrm{~S}$ was detected by smell in water from monitoring wells LCMW1-S and LCMW2-S.

Analysis of the water-chemistry data (tables 8 and 9 in appendix) from all sampling sites shows that, except for the sewer lift station (LCLS-1), the water quality at all sites was similar and predominantly a calcium bicarbonate type (fig. 9). Because Loup City's sanitary sewer contributes to the total effluent, the water chemistry at site LCLS-1 (Loup City's sewer-sanitary and storm combined) had much larger sodium and chloride concentrations than did all of the other sites. One well, BOR LC-20, contained water 
(B)
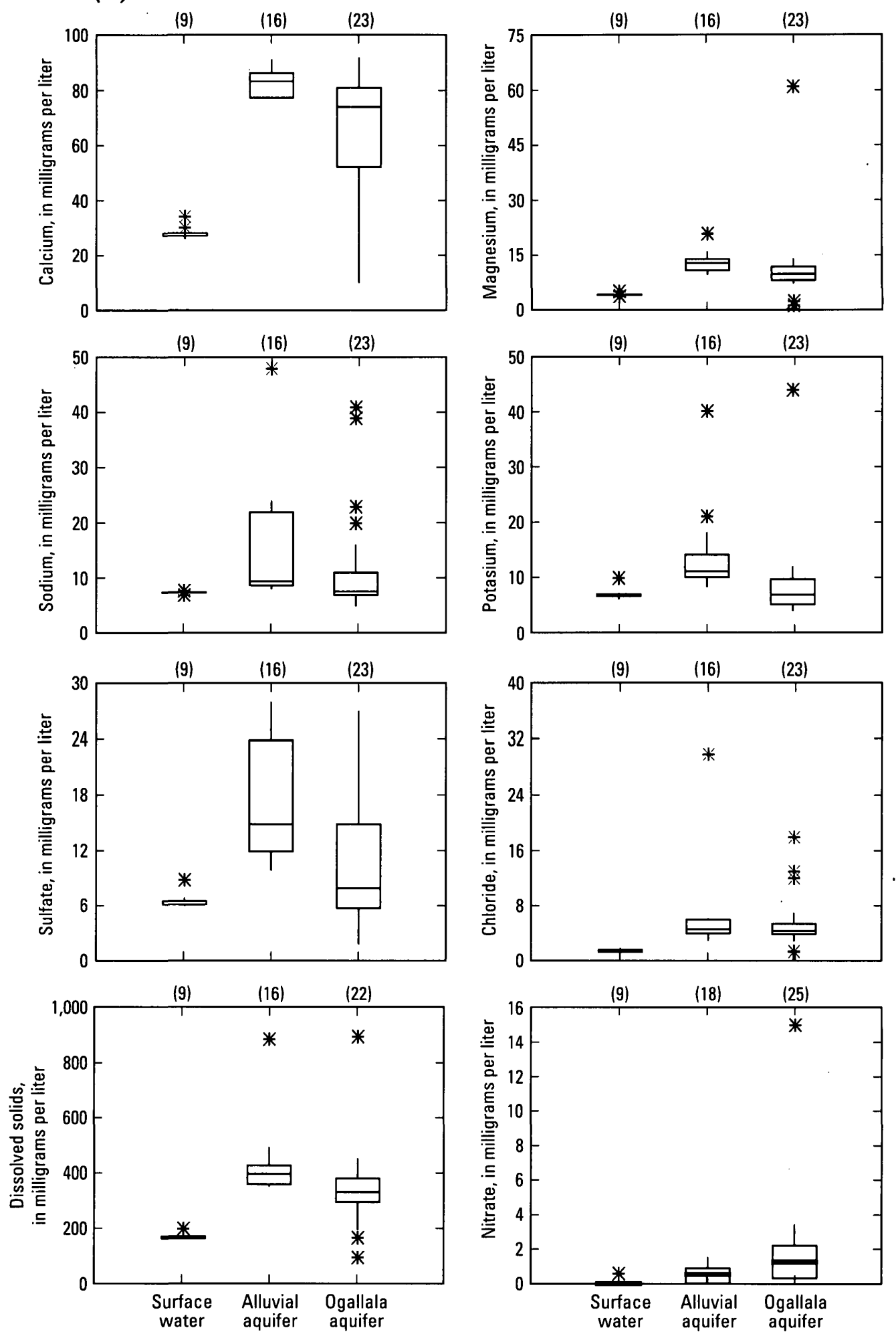

Figure 8. Distribution of (A) physical properties and (B) water-quality constituent concentrations by source in study area, 2000-Continued. 


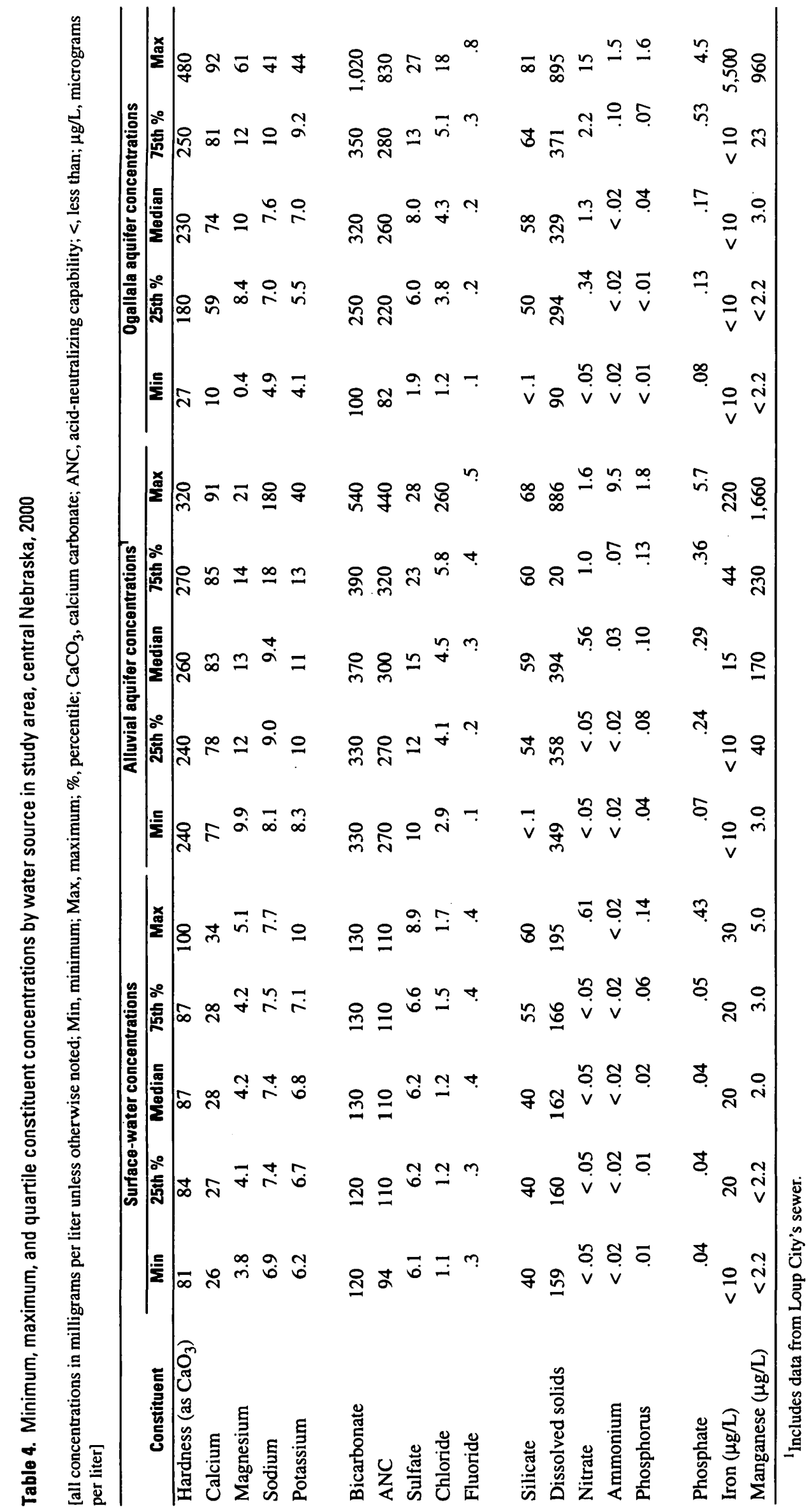




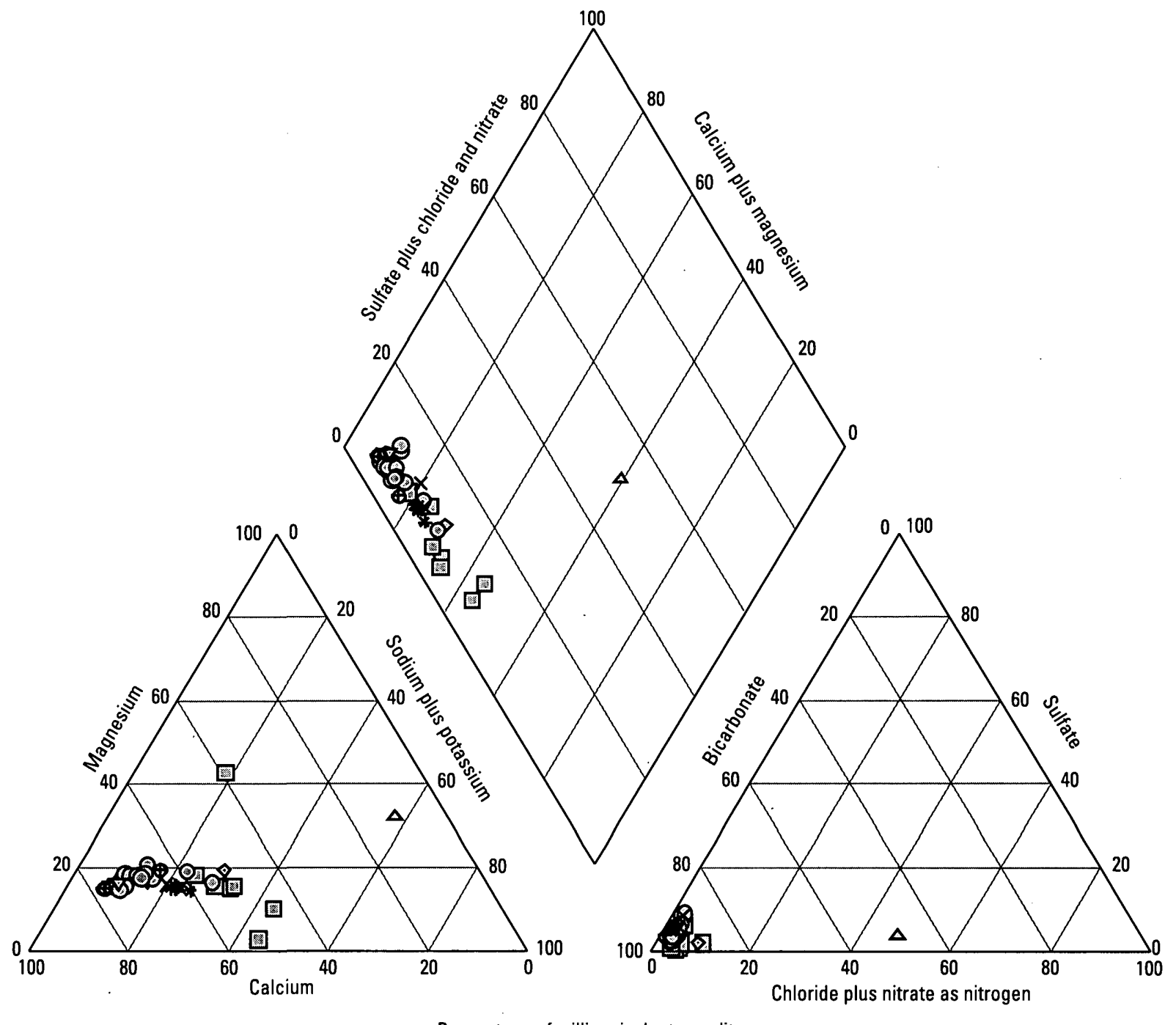

Percentage of milliequivalents per liter

\section{EXPLANATION}

$\begin{array}{ll}\text { Surface-water site } & \text { Ground-water site } \\ \times \text { Middle Loup River } & \oplus \text { Domestic well } \\ + \text { Sherman Reservoir } & \diamond \text { Loup City observation well } \\ \text { Canal Number } 4 & \odot \text { Multi-level monitoring well } \\ & \text { @ Bureau of Reclamation observation well } \\ & \nabla \text { Public-supply well LCPS-1 } \\ & \Delta \text { Sewer LCLS-1 }\end{array}$

Figure 9. Ionic composition of surface water and ground water in study area, 2000. Location of sampling sites shown in figure 2.

with a larger magnesium concentration than did all other sites. This well is at the northern edge of Loup City and is only about $20 \mathrm{ft}$ deep. The reason for the larger magnesium concentration was not determined, and the complexity of the ground-water system precludes definitive explanation.
Surface-water samples exhibited similar concentrations for ionic compositions (fig. 9) during both sampling periods. This suggests that the chemical concentrations in Sherman Reservoir did not change much, if at all, following diversions from the Middle Loup River. The water-chemistry data at distinct depths in the lake were nearly identical (tables 8 
and 9), probably indicating that (1) the system was well mixed, (2) evaporative process had little effect on the overall chemistry of the lake, and (3) chemical species were not concentrating in the lake.

The ground-water sites varied more in water chemistry than did the surface-water sites. Water samples from the domestic wells, the Loup City observation wells, and the multi-level monitoring wells all had a large calcium component. However, water samples from most of the BOR observation wells showed larger sodium concentrations (fig. 8) than did water samples from the other wells. This could indicate that the BOR observation wells are open to the shallower alluvial deposits overlying the Ogallala Formation whose water typically contains larger concentrations of calcium. The large concentrations of calcium in water samples from the domestic, Loup City observation, and multi-level monitoring wells indicate that (1) all of the domestic wells are open to the deeper Ogallala aquifer and (2) the Loup City observation and multi-level monitoring wells all contained water that currently is in the Ogallala aquifer (wells LCMW1-D and LCMW2-D) or once was in the Ogallala aquifer.

Significant differences in concentrations of calcium, magnesium, dissolved solids, and nitrate in samples from the alluvial and Ogallala aquifers (p-values ranged from 0.00 to 0.02 ) and from surfacewater and ground-water sources ( $p$-values ranged from 0.00 to 0.01 ) were detected. In addition, significant differences in sodium, potassium, and sulfate concentrations were detected in samples collected from the surface-water sites and the alluvial aquifer, and from the Ogallala aquifer and the alluvial aquifer (all $\mathrm{p}$-values less than 0.02). However, differences in concentrations of these constituents were insignificant in samples collected from the surface-water sites and the Ogallala aquifer ( $\mathrm{p}$-values ranged from 0.23 to 0.88 ). Differences in concentrations of chloride in surface-water samples were significant with respect to ground-water samples ( $\mathrm{p}$-value $=0.00$ ). However, concentrations of chloride in samples from the alluvial and Ogallala aquifers were insignificant ( $\mathrm{p}$-value = 0.39 ). These differences further support evidence of the variance in water chemistry between samples from the alluvial and Ogallala aquifers, and from surfacewater and ground-water sources.

\section{Age of Ground Water}

Analysis of the CFC data shows that $\mathrm{CFC}-11$ and CFC-113 concentrations (table 5) in some of the water samples could have degraded or were contaminatedCFC -11 and CFC -113 typically are not as stable as CFC-12 (Plummer and Busenberg, 2000). Therefore, the modeled age of the water is reported herein from CFC-12 data, which was not contaminated, and is the maximum age of the young fraction of water.

Testing of the CFC data for sensitivity showed that the assumptions were valid and that the modeled recharge age of the water was realistic. Testing the CFC data for differing mixing scenarios of binary water (old mixed with young) was inconclusive but did show that the water underlying Loup City was either not a mixture of young and old water or it was a mixture of old and very old water. Likewise, testing for piston, binary, or exponential-flow characteristics did not refute the assumption that piston flow dominated the ground-water flow regime. Although some of the water samples showed anoxic conditions from low dissolved-oxygen measurements and the smell of $\mathrm{H}_{2} \mathrm{~S}$, sulfate-reducing conditions appeared limited, and no methanogenic conditions were indicated by the water chemistry or dissolved-gases data. Therefore, except for the possible degradation of CFC-11 or $\mathrm{CFC}-113$ in some of the water samples, degradation of CFC-12 probably was negligible.

Age dates of the surface-water sites indicate that they contain modern water (less than 10 years old) (table 6). The modeled recharge dates of the ground water underlying Loup City ranged from the mid1940 s to early 1960 s. Specifically, ground water in the alluvial aquifer and at the top of the Ogallala aquifer was about 50 to 55 years old. The water sample from $300 \mathrm{ft}$ below the top of the Ogallala aquifer and directly underlying Loup City (well LCPS-1; mid- to late 1950s) was about 10 years younger than water samples from the top of the Ogallala aquifer [wells LCMW1-D and LCMW2-D; mid- to late 1940s (near the detection limit of CFC analysis)]. Water samples from the multi-level monitoring wells open at the base of the alluvial aquifer (wells LCMW1-M and LCMW2-M) show modeled ages of mid- to late 1940s (table 6). Water samples collected from the multi-level monitoring wells open to the top of the alluvial aquifer (wells LCMW1-S and LCMW2-S) show modeled ages of late 1950s to early 1960s. Analysis of samples from the only domestic well that was analyzed for CFC data (well SRGP-1; mid-1970s) indicates water 


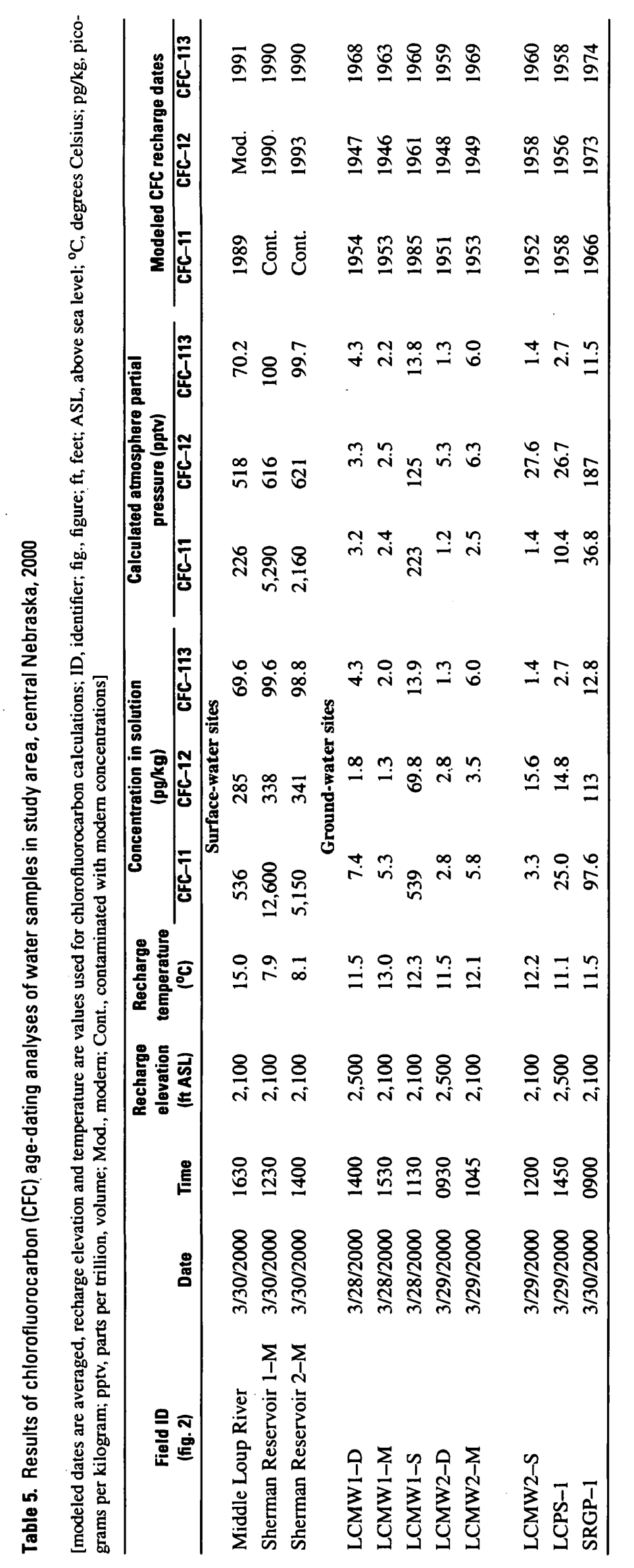


Table 6. Averaged modeled age of water samples from study area in central Nebraska analyzed for chlorofluorocarbons (CFCs) and tritium, 2000

[CFC ages were based on average of three dichlorodifluoromethane values and are the modeled date of recharge; ID, identifier; fig., figure; CFC-12, dichlorodi-fluoromethane; SW, surface water; Modern, less than 10 years old; --, not sampled; colored table cells indicate ages that are post (younger than) Sherman Reservoir construction]

\begin{tabular}{|c|c|c|c|}
\hline $\begin{array}{l}\text { Field ID } \\
\text { (fig. 2) }\end{array}$ & $\begin{array}{l}\text { Hydrologic } \\
\text { system }\end{array}$ & $\begin{array}{c}\text { Age of } \\
\text { water based on } \\
\text { CFC-12 data }\end{array}$ & $\begin{array}{c}\text { Age of water } \\
\text { based on tri- } \\
\text { tium data }\end{array}$ \\
\hline \multicolumn{4}{|c|}{ Surface-water sites } \\
\hline Sherman Reservoir 1-M & SW & Modern & -- \\
\hline Sherman Reservoir 2-M & SW & Modern & -- \\
\hline Middle Loup River & SW & Modern & -- \\
\hline \multicolumn{4}{|c|}{ Ground-water sites } \\
\hline LCMW1-D & Ogallala & $\begin{array}{l}\text { mid- to late } \\
1940 \mathrm{~s}\end{array}$ & pre-1960 \\
\hline LCMW1-M & Alluvial $\mathrm{I}$ & mid-1940s & pre-1960 \\
\hline LCMW1-S & Alluvial e & early 1960 s & pre-1960 \\
\hline LCMW2-D & Ogallala 1 & late $1940 \mathrm{~s}$ & pre-1960 \\
\hline LCMW2-M & Alluvial 1 & late $1940 \mathrm{~s}$ & pre-1960 \\
\hline LCMW2-S & Alluvial 1 & late $1950 \mathrm{~s}$ & pre-1960 \\
\hline SRGP-1 & Ogallala $\quad 1$ & mid-1970s & post- 1960 \\
\hline LCPS-1 & Ogallala $\mathrm{I}$ & mid-to-late $1950 \mathrm{~s}$ & pre-1960 \\
\hline
\end{tabular}

young enough to originate from Sherman Reservoir. Therefore, evaluation of the CFC data indicates that the age of the ground water beneath Loup City predates the construction of Sherman Reservoir.

Further evaluation of the age of ground water directly beneath Loup City indicates that the sample from multi-level monitoring well LCMW1-S was the only water sample that contained water young enough to have resided in Sherman Reservoir. The dates of water in all other samples collected from the monitoring wells in Loup City or Loup City's public-supply well predate Sherman Reservoir. Therefore, because the ages of ground water in almost all monitoring wells predate construction of Sherman Reservoir, the ground water underlying Loup City likely did not originate from Sherman Reservoir or from recent precipitation.

\section{Isotopic Data}

Results of the analyses for ${ }^{18} \mathrm{O}$ and ${ }^{2} \mathrm{H}$ in water samples show that water in Sherman Reservoir has been affected by evaporation for at least March through July and likely throughout the remainder of the irrigation and growing season. This is indicated by data representing Sherman Reservoir samples plotting below the LMWL (fig. 10). Ground water beneath Loup City does not show this relation to the LMWL. Therefore, the water from which these ground-water samples originated did not undergo evaporative processes such as those that occurred in Sherman Reservoir, indicating that the ground water beneath Loup City has not resided in Sherman Reservoir.

\section{Oxygen and Hydrogen}

Several observations can be made related to the isotopic data from analyses of surface-water and ground-water samples for stable oxygen and hydrogen isotopes (fig. 10, table 7). First, both graphs in figure 10 show that water in Sherman Reservoir plots below the LMWL and has an enriched $\delta^{18} \mathrm{O}$ and $\delta^{2} \mathrm{H}$ signature ( -7.4 per mil and -60 per mil, respectively) relative to local meteoric ground water, which is indicative of evaporation. The stable isotope shift is more than 2 per mil in $\delta^{18} \mathrm{O}$ indicating that stable isotopes of water provide a useful tracer to determine if reservoir water is present in the monitoring wells. Water samples from the Middle Loup River and Canal 4 also show evidence of evaporation (fig. 10).

Water samples from domestic well SRGP-1 [because of its relatively close position to the plotting location of water from Sherman Reservoir and because it is off the meteoric water line along an evaporation line (fig. 10)] consist of a large proportion of reservoir water either by direct hydraulic connection or as a result of reservoir seepage to the shallow ground-water system. Water from observation wells LC-20 and LC- 52 also has been affected substantially by evaporation, but the source of that water is more likely seepage from nearby Canal 4 and not from Sherman Reservoir.

Many of the remaining ground-water samples appear to have been affected by slight evaporation, but this possibly results from evaporation at the time of recharge and not from seepage from Sherman Reservoir. Data are inconclusive, but the slight evaporative signature also may reflect the effect of seepage locally to the shallow aquifer from the Middle Loup River or Canal 4. On the basis of plots in figure 10, it is estimated that unaffected ground water in the region should have $\delta{ }^{18} \mathrm{O}$ and $\delta^{2} \mathrm{H}$ signatures of about -10 and -72 per mil, respectively. These values are similar to the average weighted yearly mean values reported for precipitation in central Nebraska (-9.6 per 


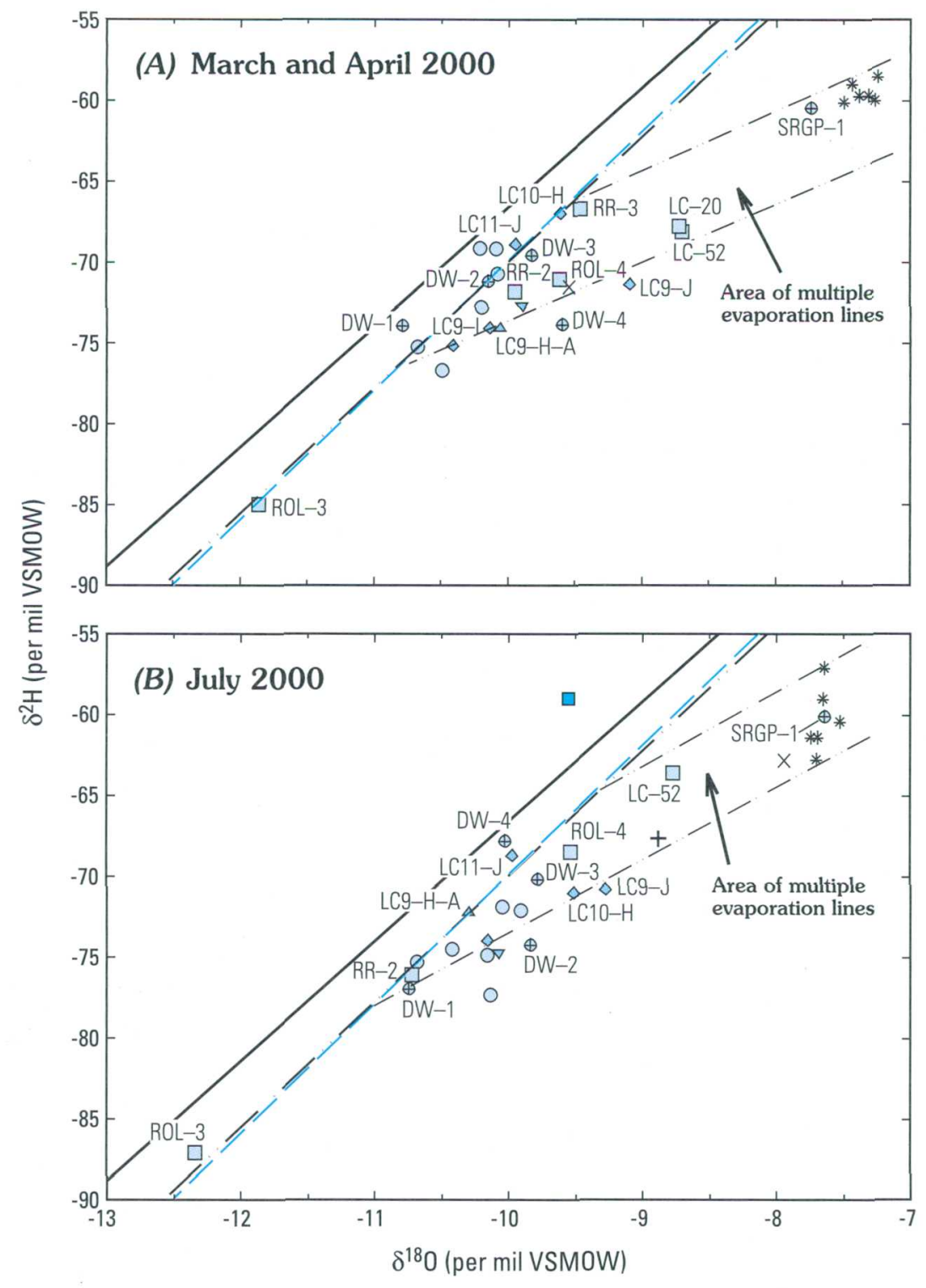

\section{EXPLANATION}

- Global meteoric water line (GMWL)

Local meteoric water line (LMWL) at Mead, Nebraska

- Local meteoric water line (LMWL) at North Platte, Nebraska

Surface-water sites

* Sherman Reservoir

$\times$ Middle Loup River

+ Canal Number 4

Ground-water sites and identifiers

DW-1 $\oplus$ Domestic well

LC10-H॰ Loup City observation well

- Multi-level monitoring well

ROL-4 $\square$ Bureau of Reclamation observation well

$\nabla$ Public-supply well LCPS-1

$\Delta$ Sewer LCLS-1

๑ Precipitation

Figure 10. Oxygen $\left(\delta^{18} 0\right)$ and stable hydrogen $\left(\delta^{2} \mathrm{H}\right)$ composition of water samples from study area for (A) March and April 2000, and (B) July 2000 (VSMOW = Vienna Standard Mean Oceanic Water). Location of sampling sites shown in figure 2. 
Table 7. Isotopic chemistry data for water samples collected in study area, central Nebraska, 2000

[change from Vienna Standard Mean Oceanic Water (VSMOW) unless otherwise indicated, in per mil; ID, identifier; fig., figure; $\delta$, delta; ${ }^{18} \mathrm{O}$, oxygen-18; ${ }^{2} \mathrm{H}$, deuterium; ${ }^{3} \mathrm{H}$, tritium; TU, tritium units; \pm , plus or minus; -- , not sampled]

\begin{tabular}{|c|c|c|c|c|c|c|c|c|}
\hline \multirow[b]{2}{*}{$\begin{array}{l}\text { Field ID } \\
\text { (fig. 2) }\end{array}$} & \multicolumn{4}{|c|}{ March and April } & \multicolumn{4}{|c|}{ July } \\
\hline & $\delta^{180}$ & $\delta^{2} \mathrm{H}$ & $\begin{array}{l}{ }^{3} \mathrm{H} \\
\text { (TU) }\end{array}$ & $\begin{array}{l}{ }^{3} \text { Herror } \\
( \pm T U)\end{array}$ & $\delta^{18} 0$ & $\delta^{2} H$ & $\begin{array}{l}3^{3} \mathrm{H} \\
\text { (TU) }\end{array}$ & $\begin{array}{l}{ }^{3} \mathrm{H} \text { error } \\
( \pm \mathrm{TU})\end{array}$ \\
\hline Precipitation & -- & -- & -- & & -9.6 & -59 & 12.6 & 1.1 \\
\hline \multicolumn{9}{|c|}{ Surface-water sites } \\
\hline Middle Loup River & -9.5 & -72 & 4.58 & 0.93 & -7.9 & -63 & -- & -- \\
\hline Sherman Reservoir 1-D & -7.3 & -60 & 5.99 & .91 & -7.7 & -63 & -- & -- \\
\hline Sherman Reservoir 1-M & -7.5 & -60 & 5.61 & .87 & -7.7 & -61 & -- & -- \\
\hline Sherman Reservoir 1-S & -7.4 & -60 & 5.26 & .96 & -7.7 & -61 & -- & -- \\
\hline Sherman Reservoir 2-D & -7.3 & -60 & 6.25 & .89 & -7.5 & -60 & -- & -- \\
\hline Sherman Reservoir 2-M & -7.4 & -59 & 6.04 & .95 & -7.7 & -59 & -- & -- \\
\hline Sherman Reservoir 2-S & -7.3 & -58 & 5.13 & .95 & -7.6 & -57 & -- & -- \\
\hline Canal Number 4 & -- & -- & -- & -- & -8.9 & -68 & -. & -. \\
\hline \multicolumn{9}{|c|}{ Ground-water sites } \\
\hline BOR LC-20 & -8.7 & -68 & 4.21 & .85 & -- & -- & -- & -- \\
\hline BOR LC-52 & -8.7 & -68 & 3.92 & .80 & -8.8 & -64 & -- & -- \\
\hline BOR ROL-3 & -11.9 & -85 & 0.29 & .64 & -12.3 & -87 & -- & -- \\
\hline BOR ROL -4 & -9.6 & -71 & 1.51 & .81 & -9.5 & -69 & -- & -- \\
\hline BOR RR-2 & -9.9 & -72 & 3.51 & .83 & -10.7 & -76 & -- & -- \\
\hline BOR RR-3 & -9.5 & -67 & 12.28 & 1.01 & -- & -- & -- & -- \\
\hline DW-1 & -10.8 & -74 & .69 & .73 & -10.7 & -77 & -- & -- \\
\hline DW-2 & -10.1 & -71 & 8.46 & .94 & -9.8 & -74 & -- & -- \\
\hline DW-3 & -9.8 & -70 & 5.06 & .89 & -9.8 & -70 & -- & -- \\
\hline DW-4 & -9.6 & -74 & 7.53 & 1.04 & -10.0 & -68 & -- & -- \\
\hline SRGP-1 & -7.7 & -60 & 6.22 & .91 & -7.7 & -60 & -- & -- \\
\hline LC9-H-A & -10.1 & -74 & 1.05 & .80 & -10.1 & -74 & -- & -- \\
\hline LC9-I & -10.4 & -75 & 1.06 & .79 & -- & -- & - & -- \\
\hline LC9-J & -9.1 & -71 & 1.70 & .78 & -9.3 & -71 & -- & -- \\
\hline LC10-H & -9.6 & -67 & .97 & .76 & -9.5 & -71 & -- & -- \\
\hline LC11-J & -9.9 & -69 & .90 & .75 & -10.0 & -69 & -- & -- \\
\hline LCLS-1 & -10.1 & -74 & 1.94 & .87 & -10.3 & -72 & -- & -- \\
\hline LCMW 1-S & -10.2 & -73 & .13 & .66 & -10.2 & -75 & -- & -- \\
\hline LCMW1-M & -10.7 & -75 & .39 & .85 & -10.4 & -75 & -- & -- \\
\hline LCMW1-D & -10.5 & -77 & .53 & .73 & -10.7 & -75 & -- & - \\
\hline LCMW2-S & -10.1 & -69 & .95 & .73 & -9.9 & -72 & -- & -- \\
\hline LCMW2-M & -10.2 & -69 & .81 & .71 & -10.1 & -72 & -- & -- \\
\hline LCMW2-D & -10.1 & -71 & .88 & .75 & -10.1 & -77 & -- & -- \\
\hline LCPS-1 & -9.9 & -73 & 1.82 & .89 & -10.1 & -75 & -- & -- \\
\hline
\end{tabular}


mil for $\delta^{18} \mathrm{O}$ and -69 per mil for $\delta^{2} \mathrm{H}$ ) reported by Harvey and Welker (2000), and with ground-water values from other studies in the region (Schellpeper and Harvey, 1998).

\section{Tritium}

Tritium was detected in all of the water samples, with concentrations ranging from 0.13 to $12.6 \mathrm{TU}$ (table 7). Although several general observations can be made, it is difficult to interpret the ${ }^{3} \mathrm{H}$ values in this study without additional information because the values are close to the mean detection limit of $0.85 \mathrm{TU}$. The precipitation sample collected in July had a value of $12.6 \mathrm{TU}$, which is consistent with modern precipitation values determined elsewhere in the region (unpublished data, F. Edwin Harvey, School of Natural Resource Sciences and Conservation and Survey Division, University of Nebraska-Lincoln, 2000). The Sherman Reservoir values, which represent a more time-integrated sample than the other samples, generally were about 5 to $6 \mathrm{TU}$ (table 7). This indicates that a more likely local average yearly precipitation value may be 6 TU or that the Sherman Reservoir samples may be a mixture of precipitation and groundwater base flow, which is believed to contain little or no ${ }^{3} \mathrm{H}$ on the basis of water samples from wells in the area. Without additional information on the relative contribution of ground water to upstream sources, it is not clear which scenario is correct. The majority of the samples had very low ${ }^{3} \mathrm{H}$ values (less than 6 to $12 \mathrm{TU}$ ) (table 7), indicating that the water was recharged prior to the 1960 s (table 6).

Assuming pre- $1950{ }^{3} \mathrm{H}$ concentrations in ground water are no greater than 6 to $7 \mathrm{TU}$, water containing greater than 0.5 TU today (2000) can be used to indicate some component of young (post-1952) water in the sample (Solomon and Cook, 2000). To verify the concordance of the ${ }^{3} \mathrm{H}$ and $\mathrm{CFC}$ dates, all ${ }^{3} \mathrm{H}$ concentrations from the water samples were back calculated from the 2000 collection date (fig. 11). The results shown in figure 11 indicate that all water samples collected in wells from Loup City have decayed from water that was present before 1960 and, thus, are concordant with the CFC data, which provide for a more accurate date of recharge.

\section{SOURCES OF GROUND WATER}

Analysis of the physical and chemical data from the water samples precludes determination of a definitive source of the ground water beneath Loup City. The data presented here show that Sherman Reservoir is not the direct source of the ground water because the isotopic signature of the ground-water samples from monitoring wells in Loup City do not show evidence of a Sherman Reservoir component, and the age of the ground water beneath Loup City predates Sherman Reservoir. The age of the ground water also rules out local precipitation as its source. However, it is possible that (1) the water seeping from Sherman Reservoir has not moved as far as Loup City, (2) the ground water underlying Loup City is older water whose flow paths have been changed by the ground-water mound underlying Sherman Reservoir, or (3) Sherman Reservoir is not affecting the ground-water-flow paths beneath Loup City. An argument can be made against option 1 because, on the basis of figure 7, ground-water levels between Sherman Reservoir and Loup City have stabilized, thus indicating that the water from Sherman Reservoir has had time to reach Loup City.

An estimate of the average linear horizontal ground-water-flow velocity in the shallowest parts of the Ogallala aquifer (which, for the purposes of this report, also include the Pliocene-age alluvial deposits overlying the Ogallala Formation) can be calculated by using Darcy's law as described by Hall and others (1991, p. 172) plus the hydraulic conductivity, effective porosity (Olsson Environmental Services, Inc., 1997) (100 ft/d and 0.30, respectively), and groundwater head differences reported previously for the Ogallala aquifer (0.0064 ft/ft). Darcy's law, including effective porosity, is written as:

$$
V=\frac{K I}{n}
$$

where

$V=$ average linear ground-water-flow velocity, in feet per day;

$K=$ horizontal hydraulic conductivity, in feet per day;

$I=$ horizontal hydraulic gradient, in feet per foot; and

$n=$ effective porosity, as a decimal fraction.

Using equation 3 , the average linear velocity for the Ogallala aquifer is about $2.3 \mathrm{ft} / \mathrm{d}$. Therefore, if an assumption is made that surface-water seepage started shortly after Sherman Reservoir was completed (1962) 
Surface-water sites

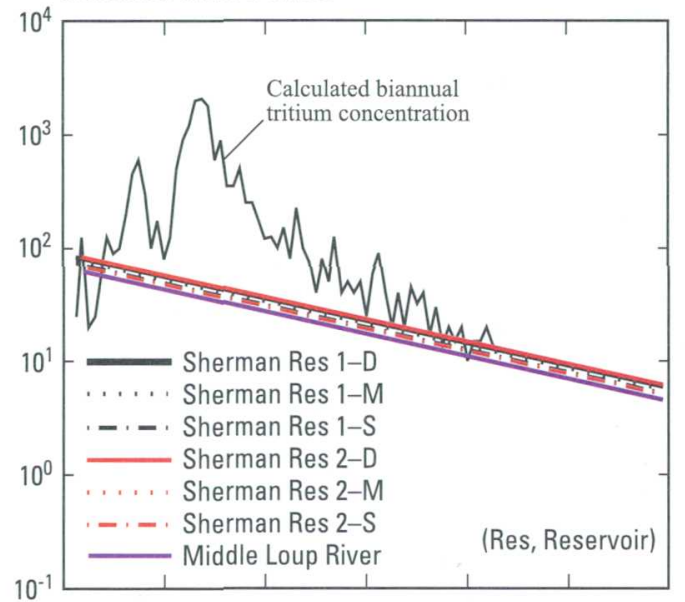

Loup City observation and public-supply wells

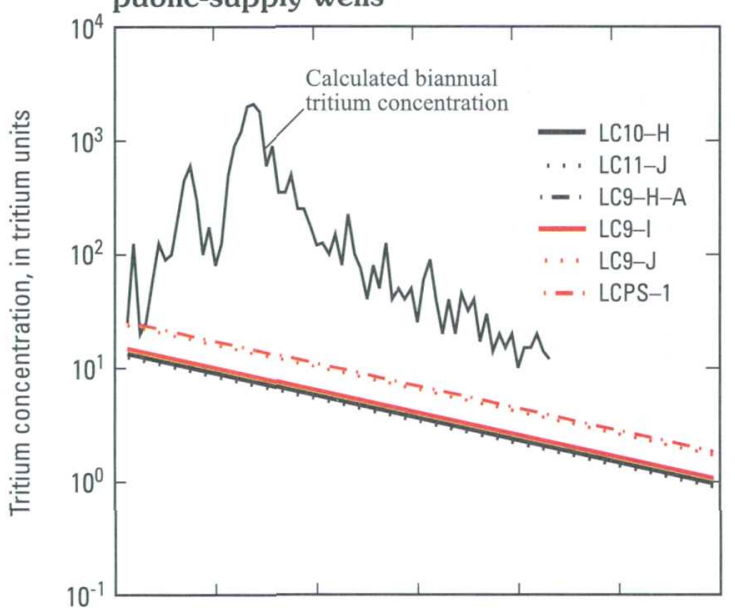

Bureau of Reclamation observation wells

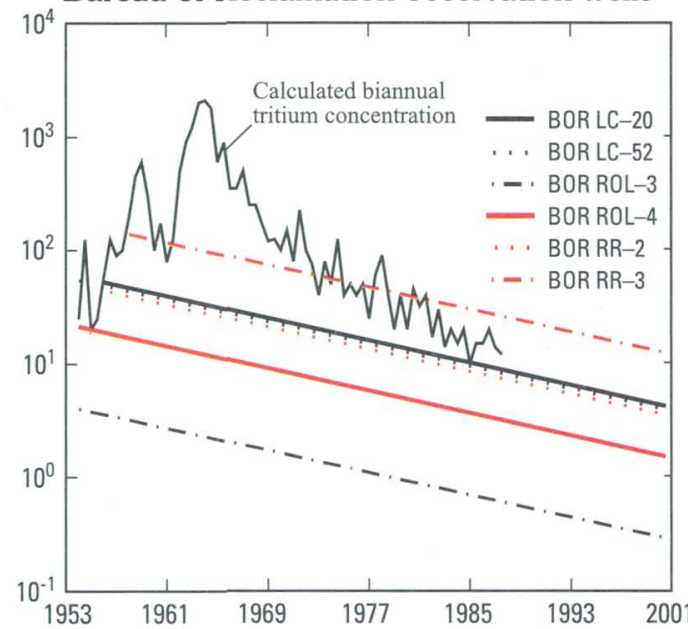

Domestic wells

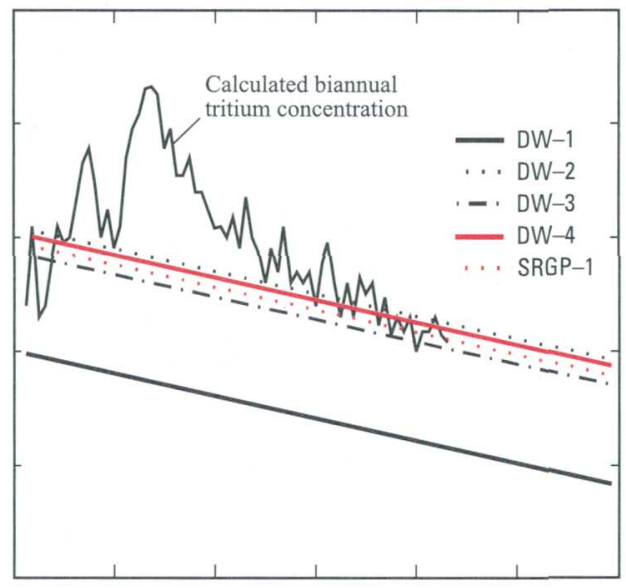

Multi-level monitoring wells

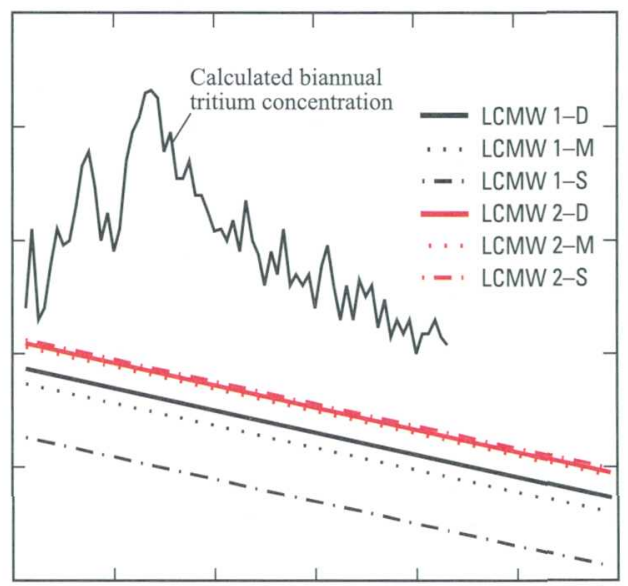

Calculated and measured tritium concentrations in precipitation

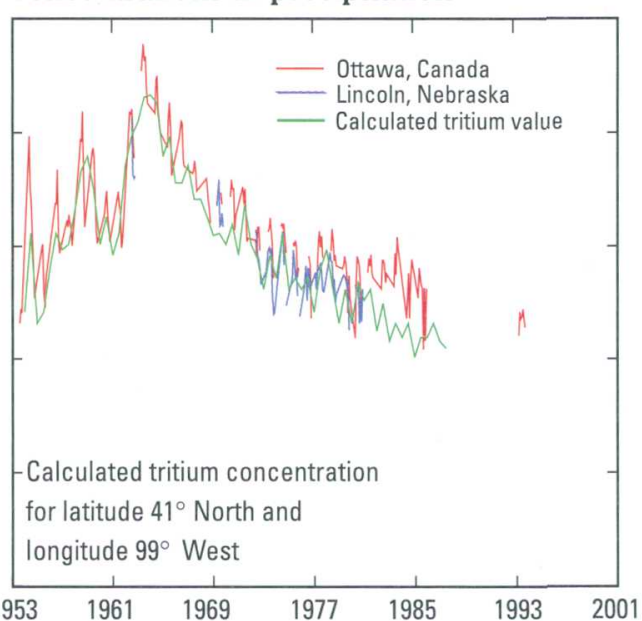

Figure 11. Tritium concentrations in water samples collected from study area in 2000 and back calculated to estimate historic concentrations. Location of sampling sites shown in figure 2. 
and water from Sherman Reservoir traveled in the Pliocene-age alluvial deposits and the shallowest part of the Ogallala Formation, it would take ground water about 9,900 days (about 27 years) to travel the $4.3 \mathrm{mi}$ $(22,700 \mathrm{ft}$ ) distance from Sherman Reservoir (at the thalweg of Oak Creek Valley) to Loup City. This is well within the time frame between the construction of Sherman Reservoir and the present day (2000).

An argument also can be made against option 3 because a hydraulic gradient exists from Sherman Reservoir toward Loup City, which results from water seeping from Sherman Reservoir. Therefore, it is likely that if Sherman Reservoir is affecting the ground water beneath Loup City, the pressure head that is exerted by water in Sherman Reservoir has changed the regional ground-water-flow path.

A small upward ground-water head difference of about $0.20 \mathrm{ft}$ was measured between water levels in wells in the Ogallala aquifer (wells LCMW1-D and LCMW2-D) and wells in the alluvium (wells LCMW1-M and LCMW1-S, and LCMW2-M and well LCMW2-S) at the two multi-level monitoring-well sites. This indicates that ground water has the potential to move from the underlying Ogallala aquifer into the alluvial aquifer beneath Loup City. Therefore, it is likely that, although the ground water underlying Loup City did not reside in Sherman Reservoir, the pressure head from Sherman Reservoir feasibly could have affected ground-water levels beneath Loup City and, thus, caused an increase in the hydraulic pressure between the two aquifers.

\section{SUMMARY}

Locally, ground-water levels near Sherman Reservoir have risen since the Bureau of Reclamation constructed Sherman Reservoir in 1962. Loup City, about $2.5 \mathrm{mi}$ west-southwest of Sherman Reservoir, also has experienced high ground-water levels in parts of the city. Local officials have attributed these high ground-water levels to seepage from Sherman Reservoir. In 2000, the USGS, in cooperation with the University of Nebraska-Lincoln and the city of Loup City, began a study to investigate the sources of ground water beneath Loup City, Nebraska. Waterquality samples collected in March, April, and July 2000 from 24 surface-water and ground-water sites were analyzed to quantify the source of ground water beneath Loup City. These water samples were analyzed for physical properties, major ions, nutrients, and selected isotopes $\left({ }^{18} \mathrm{O},{ }^{2} \mathrm{H}\right.$, and $\left.{ }^{3} \mathrm{H}\right)$. Samples from a subset of the sites were analyzed for $\mathrm{CFC}$ and selected dissolved gases.

Hydrographs of historical ground-water levels from BOR observation wells indicate that groundwater levels have risen about $85 \mathrm{ft}$ since Sherman Reservoir was completed in 1962. Also, a comparison of the water table before Sherman Reservoir construction with the 2000 water table shows that the groundwater-flow direction between Sherman Reservoir and Loup City has changed. This indicates that Sherman Reservoir is losing water to the ground-water system and locally affecting ground-water levels in wells between Sherman Reservoir and Loup City.

Water-quality data show that the only physical property that was substantially different between the surface water and the ground water in the alluvial and the Ogallala aquifers was the concentration of dissolved oxygen. Dissolved-oxygen concentrations in water samples from the alluvial aquifer were much smaller and significantly different than those in water samples from the Ogallala aquifer or the surfacewater sites.

Water-chemistry data indicate that the water types of all three sources were similar and predominantly were a calcium bicarbonate type. Water chemistry at the surface-water sites shows that the compositions of major ions were tightly grouped. Therefore, chemical concentrations in Sherman Reservoir did not change much following diversions from the Middle Loup River. Evaporative processes that occurred in Sherman Reservoir did not concentrate chemical species in the lake.

Water varied more in chemistry between groundwater sites than between surface-water sites. Median sulfate concentrations in water samples from the alluvial aquifer were nearly twice the median concentration of sulfate measured in water samples from the Ogallala aquifer. Water samples from the domestic wells, the Loup City observation wells, and the multilevel monitoring wells all seem to have a large calcium component. Water samples from BOR observation wells, which likely are open to the alluvial deposits overlying the Ogallala aquifer, typically contained larger sodium concentrations. The large calcium concentrations in water samples from the domestic wells, the Loup City observation wells, and the multilevel monitoring wells indicate that (1) all of the domestic wells are open to the deeper Ogallala aquifer and (2) the Loup City observation and multi-level 
monitoring wells all contain water that presently is in the Ogallala aquifer or once resided in the Ogallala aquifer.

Age-dating techniques indicate that the surfacewater sites contain modern water (less than 10 years old). However, modeled recharge dates of the ground water underlying Loup City generally ranged from mid-1940s to early 1960 s. Water samples collected from Loup City's public-supply well contained a modeled recharge date of mid- to late 1950s. Water samples collected from the shallowest multi-level monitoring wells had modeled recharge ages from late 1950 s to early 1960 s. Only water samples collected from domestic well SRGP-1 indicated water young enough, modeled recharge age of mid-1970s, to originate from Sherman Reservoir. Therefore, the age of the ground water beneath Loup City probably predates construction of Sherman Reservoir. Tritium values collected from wells in Loup City support the CFC data.

Oxygen-18 and ${ }^{2} \mathrm{H}$ isotopic data show an enriched evaporative signature for water samples collected from Sherman Reservoir, which indicates that water samples from Sherman Reservoir have undergone evaporation. Ground-water samples from two BOR observation wells in Loup City also have been affected substantially by evaporation, but the source of their water likely is from seepage from the nearby Canal 4 and not Sherman Reservoir. Many of the remaining ground-water samples appear to have been affected by slight evaporation, but this possibly results from evaporation at the time of recharge and not from seepage from Sherman Reservoir.

The sources of the water beneath Loup City cannot be determined accurately from available data. However, from analysis of the water chemistry and isotope data, it appears that the water underlying Loup City does not show evidence of a Sherman Reservoir component. Furthermore, it is likely that, although the water underlying Loup City predates construction of Sherman Reservoir, the pressure head from Sherman Reservoir feasibly could have affected ground-water levels beneath Loup City and caused an increase in the hydraulic pressure between the Ogallala and alluvial aquifers.

\section{REFERENCES}

Allison, G.B., and Hughes, M.W., 1975, The use of environmental tritium to estimate recharge to a south-Australian aquifer: Journal of Hydrology, v. 26, p. 245-254.

Atakan, Y., 1972, Bomb tritium hydrology of a sandy unconfined aquifer: Heidelberg, Germany, University of Heidelberg, Ph.D. dissertation, 102 p.

Boohar, J.A., Hoy, C.G., and Steele, G.V., 1994, Water resources data, Nebraska, water year 1993: U.S. Geological Survey Water-Data Report NE-93-1, $403 \mathrm{p}$.

Brown, D.W., 1955, Ground-water resources of the Middle Loup Division of the Lower Platte River Basin Nebraska, with a section on the chemical quality of the ground water, by F.H. Rainwater: U.S. Geological Survey Water-Supply Paper 1258, 85 p.

Bureau of Reclamation, 1989, Sherman seepage study with groundwater model: Billings, Montana, Bureau of Reclamation, GP-247, 63 p.

1996, Evaluation of Sherman Reservoir seepage impacts to the water table at Loup City, NE: Billings, Montana, Bureau of Reclamation, GP-2500, 45 p., 1 app.

1999, Drainage assessment, Middle Loup Valley area, Farwell unit, Middle Loup Division, Pick-Sloan Missouri Basin Program, Nebraska: Grand Island, Nebraska, Bureau of Reclamation, variable pagination.

Busenberg, Eurybiades, and Plummer, L.N., 1992, Use of chlorofluorocarbons $\left(\mathrm{CCL}_{3} \mathrm{~F}\right.$ and $\left.\mathrm{CCl}_{2} \mathrm{~F}_{2}\right)$ as hydrologic tracers and age-dating tools-the alluvium and terrace system of central Oklahoma: Water Resources Research, v. 28, no. 9, p. 2257-2283.

Clark, Ian, and Fritz, Peter, 1997, Environmental isotopes in hydrogeology: New York, Lewis Publishers, CRC Press, $328 \mathrm{p}$.

Cook, P.G., and Solomon, D.K., 1995, The transport of atmospheric trace gases to the water table-implications for groundwater dating with chlorofluorocarbons and krypton-85: Water Resources Research, v. 31, no. 3, p. 263-270.

Craig, H., 1961, Isotopic variations in meteoric waters: Science, v. 133, p. 1702-1703.

Daniels, D.P., Fritz, S.J., and Leap, D.I., 1989, Measurement of recharge rates through an unsaturated glacial till by tritium analyses: Lafayette, Indiana, Purdue University, Water Resources Research Center, Technical Report 18, 83 p.

Davis, S.N., and DeWiest, R.J.M., 1966, Hydrogeology: New York, Wiley, $463 \mathrm{p}$.

Domenico, P.A., and Schwartz, F.W., 1990, Physical and chemical hydrogeology: New York, Wiley, 824 p.

Dowdy, Shirley, and Wearden, Stanley, 1991, Statistics for research $(2 \mathrm{~d}$ ed.) - Wiley series in probability and mathematical statistics: New York, Wiley, 629 p. 
Egboka, B.C.E., Cherry, J.A., Farvolden, R.N., and Frind, E.O., 1983, Migration of contaminants in groundwaters at a landfill-a case study, part 3 . Tritium as an indicator of dispersion and recharge: Journal of Hydrology, v. 63, p. 51-80.

Ekwurzel Brenda, Schlosser Peter, Smethie, W.M. Jr., Plummer, L.N., Busenberg, Eurybiades, Michel, R.L., Weppernig, Ralf, and Stute, Martin, 1994, Dating of shallow groundwater - comparison of the transient tracers ${ }^{3} \mathrm{H} /{ }^{3} \mathrm{He}$, chlorofluorocarbons and ${ }^{85} \mathrm{Kr}$ : Water Resources Research, v. 30, no. 6, p. 1693-1708.

Faure, G., 1986, Principles of isotope geology: New York, Wiley, 589 p.

Fenneman, N.M., 1946, Physical divisions of the United States: U.S. Geological Survey map, scale 1:7,000,000, 1 sheet.

Fontes, J.C., 1980, Environmental isotopes in groundwater hydrology, in Fritz, P. and Fontes, J.C., eds., Handbook of environmental isotope geochemistry: Amsterdam, Elsevier Scientific, chap. 3, v. 1, The Terrestrial Environment, A, p. 75-140.

Foster, S.S.D., 1975, The chalk groundwater tritium anomaly - a possible explanation: Journal of Hydrology, v. 25, p. 159-165.

Hall, S.H., Luttrell, S.P., and Cronin, W.E., 1991, A method for estimating effective porosity and ground-water velocity: Ground Water, v. 29, no. 2, p. 172.

Harvey, F.E., 2001, Use of NADP archive samples to determine the isotope composition of precipitation-characterizing the meteoric input function for use in ground water studies: Ground Water, v. 39, no. 3, p. 380-390.

Harvey, F.E., and Welker, J.M., 2000, Stable isotopic composition of precipitation in the semi-arid northcentral portion of the U.S. Great Plains: Journal of Hydrology, v. 238, p. 90-109.

Helsel, D.R., and Hirsch, R.M., 1992, Statistical methods in water resources: Amsterdam, Elsevier Publications, $522 \mathrm{p}$.

Hem, J.D., 1985, Study and interpretation of the chemical characteristics of natural water (3d ed.): U.S. Geological Survey Water-Supply Paper 2254, 263 p.

International Atomic Energy Agency (IAEA), 1992, Statistical treatment of data on environmental isotopes in precipitation: Vienna, IAEA, Technical Report Series No. 331,781 p.

2001, Global network for isotopes in precipitation: Information available on the World Wide Web, accessed September 25, 2001, at URL http://isohis.iaea.org/Projects.asp

Larson, G.J., Delcore, M.R, and Offer, S., 1987, Application of the tritium interface method for determining recharge rates to unconfined drift aquifers, volume I, homogeneous case: Journal of Hydrology, v. 91, p. 59-72.
Lucas, L.L., and Unterweger, M.P., 2000, Comprehensive review and critical evaluation of the half-life of tritium: Journal of Research of the National Institute of Standards and Technology, v. 105, no. 4, p. 541-549.

Mann, W.B., Urterweger, M.P., and Coursey, B.M., 1982, Comments of the NBS tritiated-water standards and their use: International Journal of Applied Radiatomical Isotopes, v. 33, p. 383-386.

Mathey, S.B., (ed.), 1990, Ground-water site inventory system, v. 2, chap. 4, in National Water Information System user's manual: U.S. Geological Survey OpenFile Report 89-587, 288 p.

McDonald, M.G., and Harbaugh, A.W., 1988, A modular three-dimensional finite-difference ground-water flow model: U.S. Geological Survey Techniques of WaterResources Investigations, book 6, chap. A1, 586 p.

Miller \& Associates Consulting Engineers, P.C., 1988, Sanitary sewer evaluation study (preliminary), Loup City, Nebraska: Miller \& Associates Consulting Engineers, P.C., EPA No. C10679, M\&A Project No. 140-D1-001-88, 107 p.

National Oceanic and Atmospheric Administration, 2000, Climatological data - annual summary, Nebraska, 1999: Asheville, N.C., U.S. Department of Commerce, v. 104 , no. 13,34 p.

Nebraska Game and Parks Commission, 2000, Sherman Reservoir State Recreation Area: Information available on the World Wide Web, accessed November 14, 2000, at URL http://www.ngpc.state.ne.us/parks/ sherman.html

Olsson Environmental Sciences, Inc., 1997, Groundwater modeling, Loup City, Nebraska: Lincoln, Nebraska, Olsson Environmental Sciences, Inc., OES No. 97-0128ES.01, 28 p.

Peckenpaugh, J.M., and Dugan, J.T., 1983, Hydrogeology of parts of the Central Platte and Lower Loup Natural Resources Districts, Nebraska: U.S. Geological Survey Water-Resources Investigations Report 83-4219, 100 p., 3 pl.

Plummer, L.N., and Busenberg, Eurybiades, 2000, Chlorofluorocarbons, in Cook, P.G, and Herczeg, A.L., eds., Environmental tracers in subsurface hydrology: Boston, Kluwer Academic, p. 442-478.

Prickett; T.A., and Lonnquist, C.G., 1971, Selected digital computer techniques for groundwater resource evaluation: Illinois State Water Survey Bulletin 55, 62 p.

Robertson, W.D., and Cherry, J.A., 1989, Tritium as an indicator of recharge and dispersion in a groundwater system in central Ontario: Water Resources Research, v. 25 , no. 6, p. 1097-1109.

Schellpeper, J.J., and Harvey, F.E., 1998, Chemical and isotopic characterization of ground and surface waters in the Republican River Basin of Nebraska as a means to assess the impact of irrigation practices [abs.]: Geological Society of America Annual Meeting, 
Toronto, Ontario, Canada, October 26-29, 1998, Abstracts with Programs, v. 30, no. 7, p. A-76.

Sniegocki, R.T., 1959, Geologic and ground-water reconnaissance of the Loup River drainage basin Nebraska, with a section on the chemical quality of the ground water, by R.H. Langford: U.S. Geological Survey Water-Supply Paper 1493, $106 \mathrm{p}$

Solomon, D.K., and Cook, P.G., $2000,{ }^{3} \mathrm{H}$ and ${ }^{3} \mathrm{He}$, in Cook, P.G, and Herczeg, A.L., eds., Environmental tracers in subsurface hydrology: Boston, Kluwer Academic, p. 397-424.

Souders, V.L., 2000, Geologic maps and cross sections showing configurations of bedrock surfaces, Broken Bow $1^{\circ} \times 2^{\circ}$ quadrangle, east-central Nebraska: U.S. Geological Survey Geologic Investigations Series I-2725, 1 pl., 1 pamphlet, $11 \mathrm{p}$.

Szabo, Zoltan, Rice, D.E., Plummer, L.N., Busenberg, Eurybiades, Drenkard, Stefan, and Schlosser, Peter, 1996, Age dating of shallow groundwater with chlorofluorocarbons, tritium/helium 3 , and flow path analy- sis, southern New Jersey coastal plain: Water Resources Research, v. 32, no. 4, p. 1023-1038.

U.S. Geological Survey, 1997 to present, National field manual for the collection of water-quality data: U.S. Geological Survey Techniques of Water-Resources Investigations, book 9, chaps. A1-A9, 2 volumes, variously paged. [Also available on World Wide Web at http://water.usgs.gov/owq/FieldManual/. Chapters originally were published from 1997-99; updates and revisions are ongoing and are summarized at: http://water.usgs.gov/owq/FieldManual/ mastererrata.html].

von Buttlar, H., 1959, Ground-water studies in New Mexico using tritium as a tracer, volume II: Journal of Geophysical Research, v. 64, p. 1031-1038.

Wells, F.C., Gibbons, W.J., and Dorsey, M.E., 1990, Guidelines for collection and field analysis of water-quality samples from streams in Texas: U.S. Geological Survey Open-File Report 90-127, 79 p. 


\section{APPENDIX}


38 Use of Water Chemistry, Isotopes, and Chlorofluorocarbons to Investigate the Sources of Ground Water Beneath Loup City, Central Nebraska, 2000 


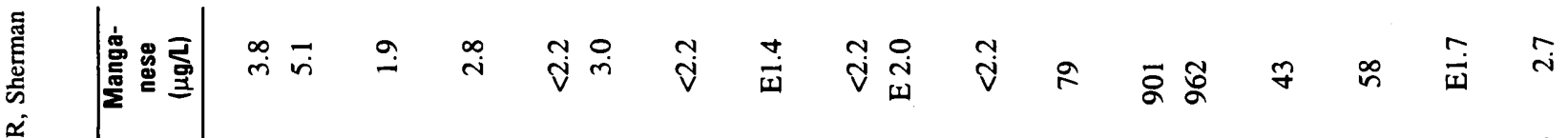

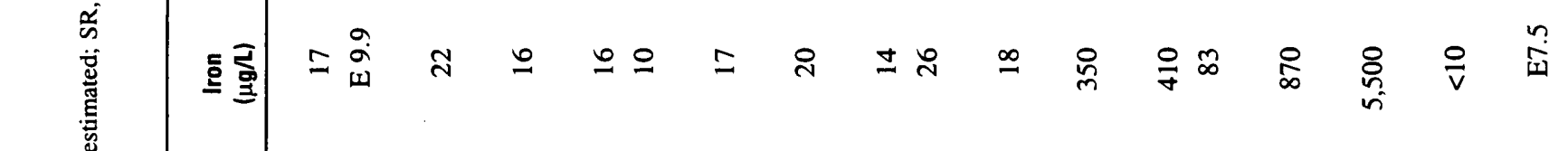

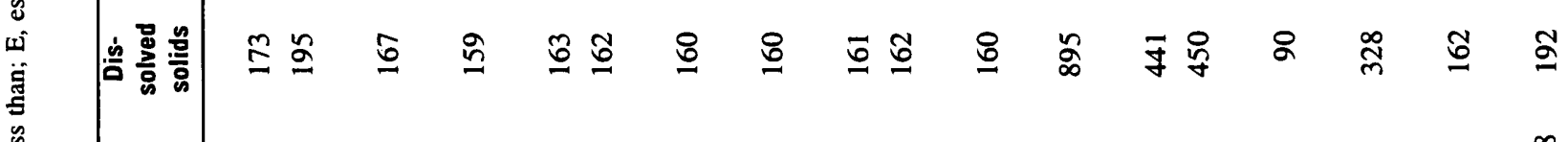

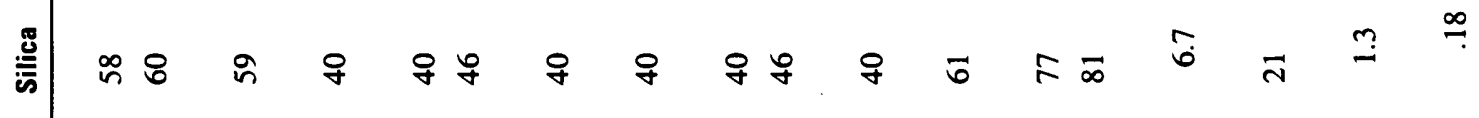

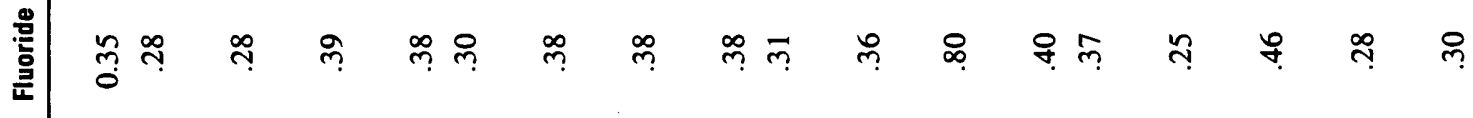

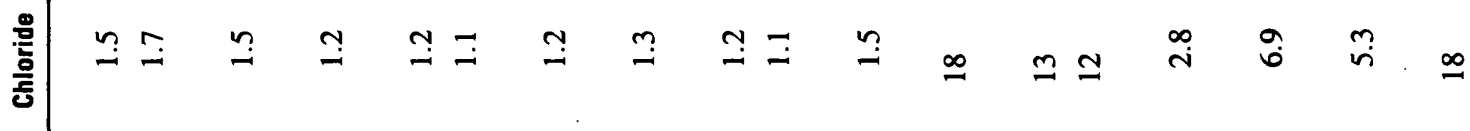
意

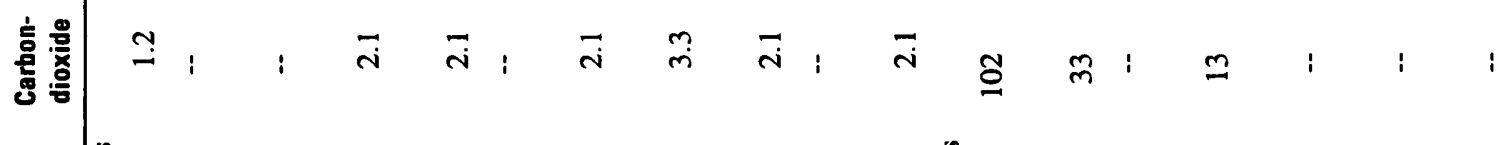

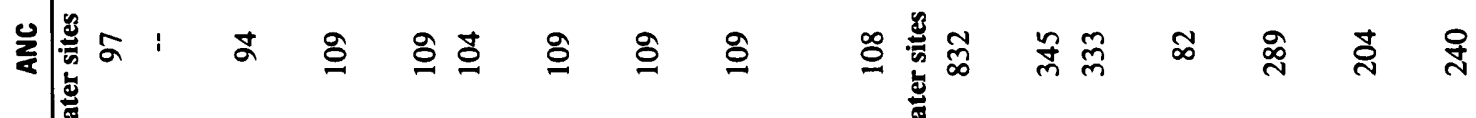
产言

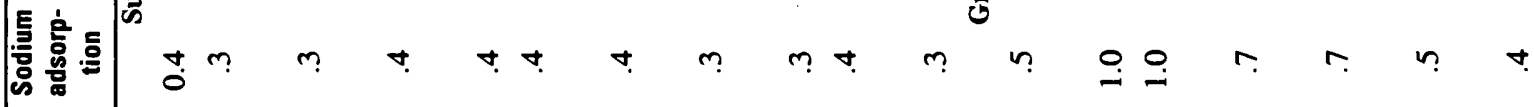

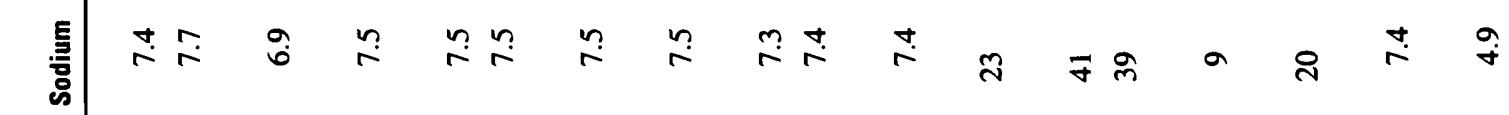

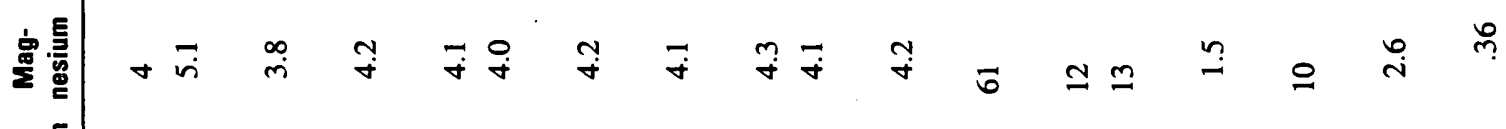
岏

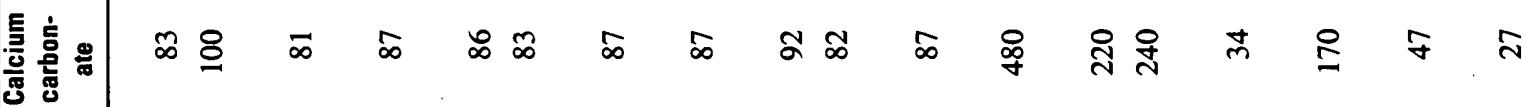

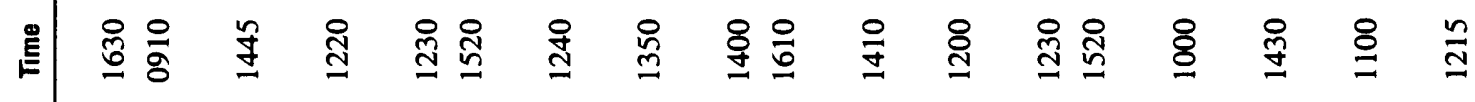

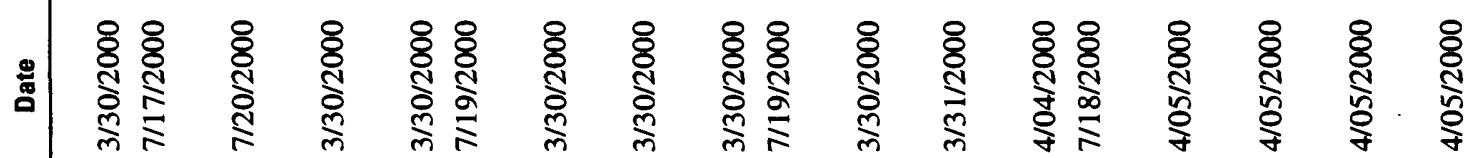

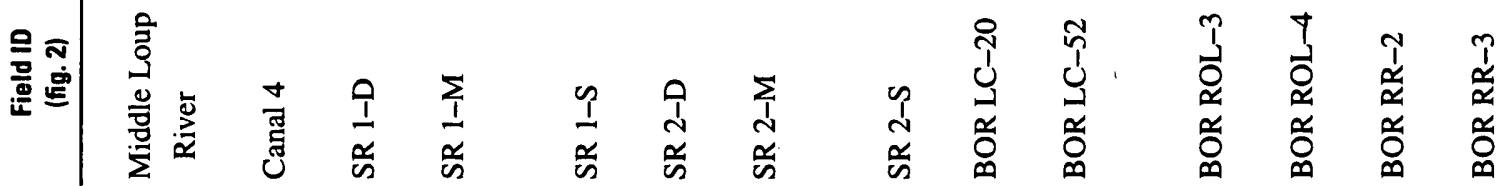




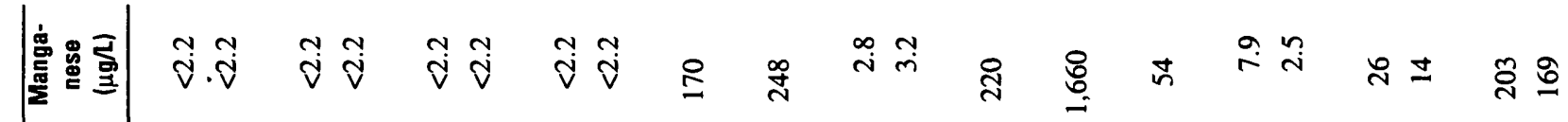

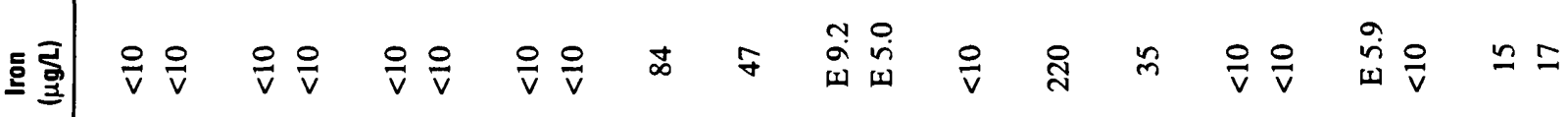

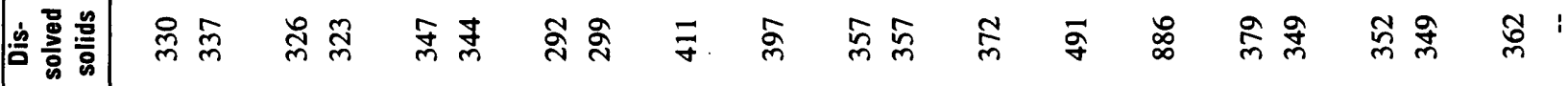
离

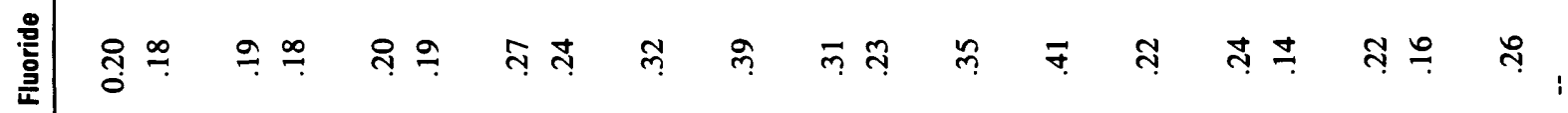

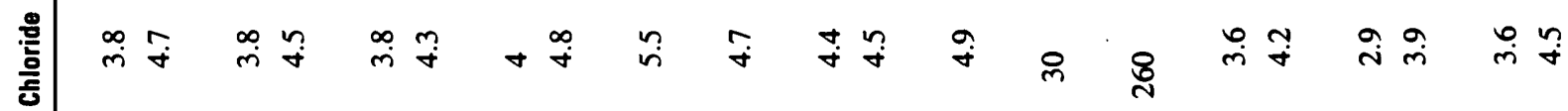

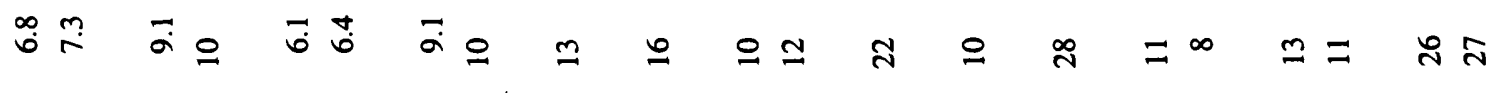
言: छ

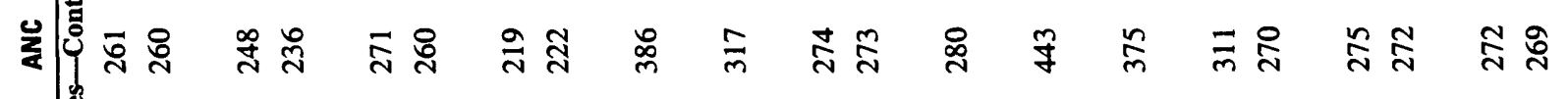

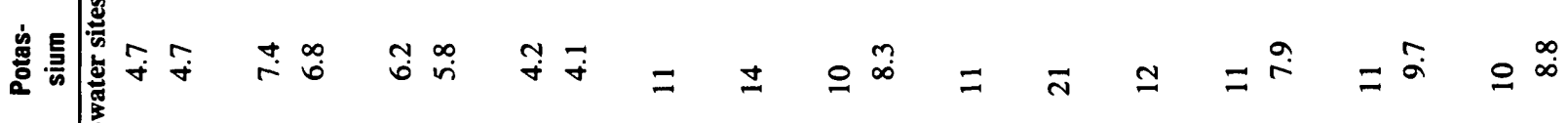
ฯ ฯ ฯ 产 要恶 ド ホே

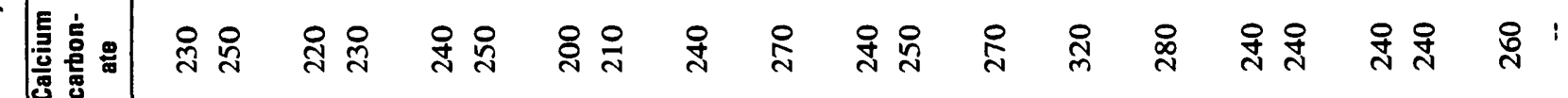

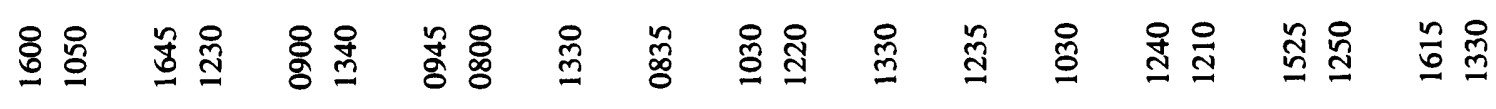

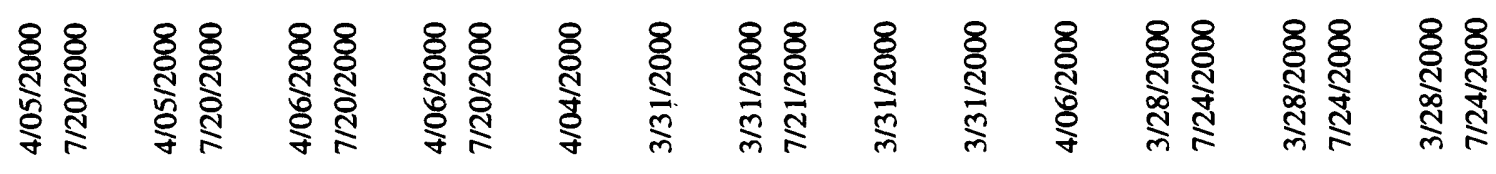




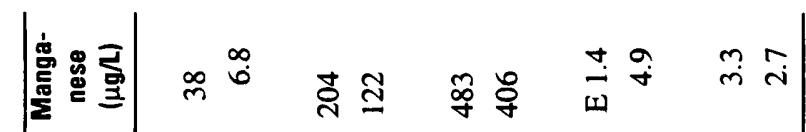
啙

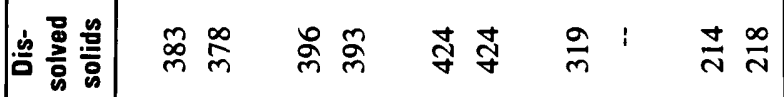

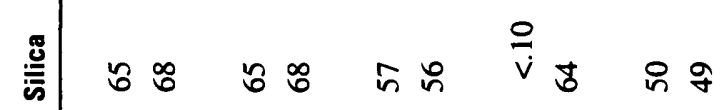

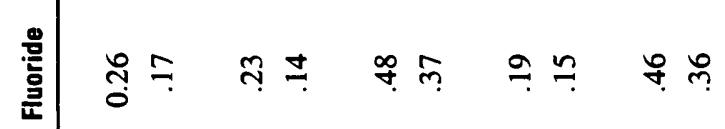

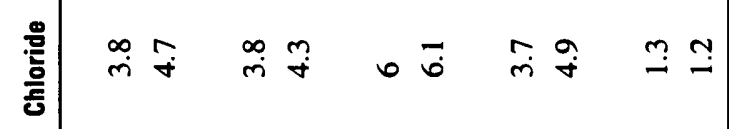

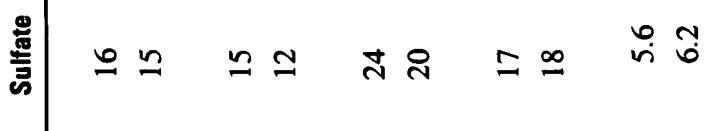

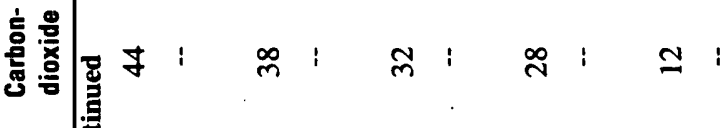

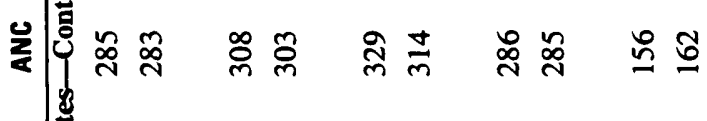

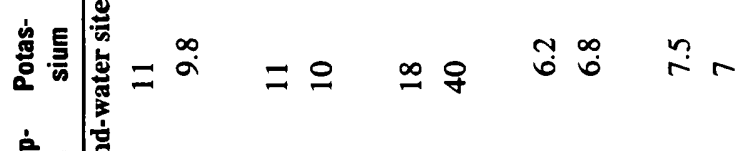

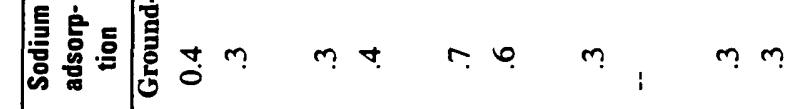
E.

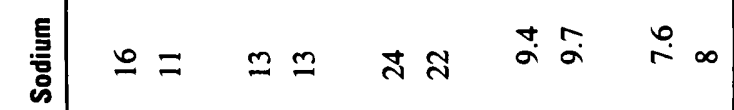

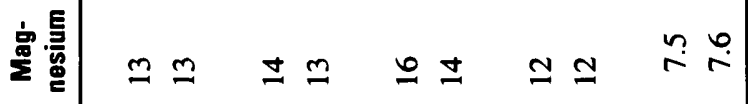
言

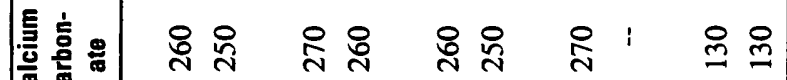
离

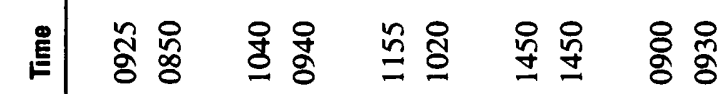

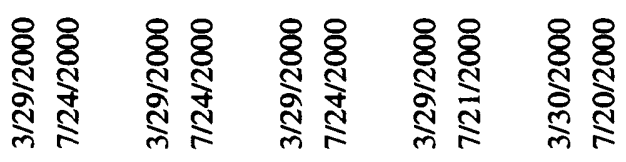

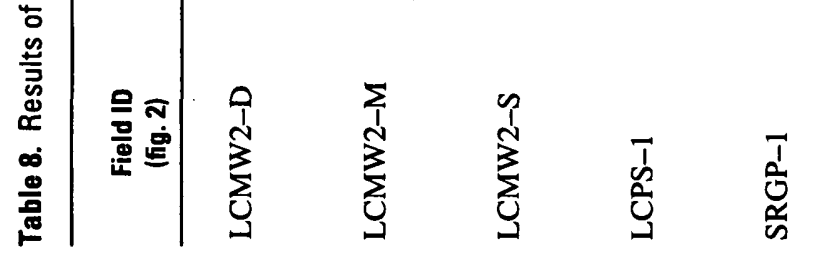


Table 9. Results of water-quality analysis for nutrients in water samples from study area, central Nebraska, 2000

[all concentrations in milligrams per liter; USGS, U.S. Geological Survey; ID, identification number or identifier; fig., figure; N, nitrogen; <, less than; --, no result]

\begin{tabular}{|c|c|c|c|c|c|c|c|c|}
\hline USGS site ID & $\begin{array}{l}\text { Field ID } \\
\text { (fig. 2) }\end{array}$ & Date & Time & Nitrate as $\mathbf{N}$ & Ammonia & Nitrite as $\mathbf{N}$ & Phosphorus & Phosphate \\
\hline & \multicolumn{8}{|c|}{ Surface-water sites } \\
\hline \multirow[t]{2}{*}{06779500} & Middle Loup River & $3 / 30 / 2000$ & 1630 & 0.611 & $<0.020$ & $<0.01$ & 0.139 & 0.43 \\
\hline & & $7 / 17 / 2000$ & 0910 & $<.050$ & $<.020$ & $<.01$ & .084 & .26 \\
\hline 06778450 & Canal 4 & $7 / 20 / 2000$ & 1445 & $<.050$ & $<.020$ & $<.01$ & .095 & .29 \\
\hline 06784195001 & Sherman Reservoir 1-D & $3 / 30 / 2000$ & 1220 & $<.050$ & $<.020$ & $<.01$ & .014 & .04 \\
\hline \multirow[t]{2}{*}{06784195002} & Sherman Reservoir 1-M & $3 / 30 / 2000$ & 1230 & $<.050$ & $<.020$ & $<.01$ & .013 & .04 \\
\hline & & $7 / 19 / 2000$ & 1520 & $<.050$ & $<.020$ & $<.01$ & .058 & .18 \\
\hline 06784195003 & Sherman Reservoir 1-S & $3 / 30 / 2000$ & 1240 & $<.050$ & $<.020$ & $<.01$ & .015 & .05 \\
\hline 06784190001 & Sherman Reservoir 2-D & $3 / 30 / 2000$ & 1350 & $<.050$ & $<.020$ & $<.01$ & .017 & .05 \\
\hline \multirow[t]{2}{*}{06784190002} & Sherman Reservoir 2-M & $3 / 30 / 2000$ & 1400 & $<.050$ & $<.020$ & $<.01$ & .014 & .04 \\
\hline & & $7 / 19 / 2000$ & 1610 & $<.050$ & $<.020$ & $<.01$ & .06 & .18 \\
\hline 06784190003 & Sherman Reservoir 2-S & $3 / 30 / 2000$ & 1410 & $<.050$ & $<.020$ & $<.01$ & .014 & .04 \\
\hline \multicolumn{9}{|c|}{ Ground-water sites } \\
\hline 411706098582201 & BOR LC-20 & $3 / 31 / 2000$ & 1200 & 15 & .187 & $<.01$ & .712 & 2.2 \\
\hline \multirow[t]{2}{*}{411700098580201} & BOR LC-52 & $4 / 04 / 2000$ & 1230 & $<.050$ & 1.46 & $<.01$ & 1.48 & 4.5 \\
\hline & & $7 / 18 / 2000$ & 1520 & $<.050$ & 1.53 & $<.01$ & 1.57 & 4.8 \\
\hline \multirow[t]{2}{*}{411912098544801} & BOR ROL-3 & $4 / 05 / 2000$ & 1000 & .338 & .025 & $<.01$ & $<.010$ & -- \\
\hline & & $7 / 19 / 2000$ & 1050 & 3.42 & .289 & .12 & $<.010$ & -- \\
\hline \multirow[t]{2}{*}{411728098574001} & BOR ROL-4 & $4 / 05 / 2000$ & 1430 & 2.15 & .038 & .01 & $<.010$ & -- \\
\hline & & $7 / 26 / 2000$ & 0730 & 1.54 & .44 & .47 & $<.010$ & -- \\
\hline \multirow[t]{2}{*}{411833098555701} & BOR RR-2 & $4 / 05 / 2000$ & 1100 & .075 & .047 & .02 & $<.010$ & -- \\
\hline & & $7 / 19 / 2000$ & 0850 & 1.17 & .16 & .01 & $<.010$ & -- \\
\hline 411649098541401 & BOR RR-3 & $4 / 05 / 2000$ & 1215 & $<.050$ & .101 & $<.01$ & $<.010$ & - \\
\hline \multirow[t]{2}{*}{411747098562001} & DW-1 & $4 / 05 / 2000$ & 1600 & 1.19 & $<.020$ & $<.01$ & .03 & .09 \\
\hline & & $7 / 20 / 2000$ & 1050 & 1.14 & $<.020$ & $<.01$ & .041 & .13 \\
\hline \multirow[t]{2}{*}{411723098562801} & DW-2 & $4 / 05 / 2000$ & 1645 & 2.53 & $<.020$ & $<.01$ & .055 & .17 \\
\hline & & $7 / 20 / 2000$ & 1230 & 2.54 & $<.020$ & $<.01$ & .073 & .22 \\
\hline \multirow[t]{2}{*}{411701098565001} & DW-3 & $4 / 06 / 2000$ & 0900 & 2.91 & $<.020$ & $<.01$ & .044 & .13 \\
\hline & & $7 / 20 / 2000$ & 1340 & 2.87 & $<.020$ & $<.01$ & .04 & .12 \\
\hline
\end{tabular}


Table 9. Results of water-quality analysis for nutrients in water samples from study area, central Nebraska, 2000—Continued

\begin{tabular}{|c|c|c|c|c|c|c|c|c|}
\hline USGS site ID & $\begin{array}{l}\text { Field ID } \\
\text { (fig. 2) }\end{array}$ & Date & Time & Nitrate as $N$ & Ammonia & Nitrite as $\mathbf{N}$ & Phosphorus & Phosphate \\
\hline \multicolumn{9}{|c|}{ Ground-water sites-Continued } \\
\hline \multirow[t]{2}{*}{411648098542401} & DW-4 & $4 / 06 / 2000$ & 0945 & 0.993 & $<0.020$ & $<0.01$ & 0.025 & 0.08 \\
\hline & & $7 / 20 / 2000$ & 0800 & .857 & $<.020$ & $<.01$ & .025 & .08 \\
\hline \multirow[t]{2}{*}{411656098581701} & LC10-H & $4 / 04 / 2000$ & 1330 & .521 & .061 & .01 & .096 & .29 \\
\hline & & $7 / 21 / 2000$ & 1340 & .929 & $<.020$ & .01 & .079 & .24 \\
\hline \multirow[t]{2}{*}{411648098582301} & LC11-J & $3 / 31 / 2000$ & 0835 & $<.050$ & .03 & $<.01$ & .106 & .33 \\
\hline & & $7 / 21 / 2000$ & 0800 & $<.050$ & .033 & $<.01$ & .116 & .36 \\
\hline \multirow[t]{2}{*}{411654098581501} & LC9-H-A & $3 / 31 / 2000$ & 1030 & 1.37 & $<.020$ & $<.01$ & .089 & .27 \\
\hline & & $7 / 21 / 2000$ & 1220 & 1.21 & $<.020$ & $<.01$ & .094 & .29 \\
\hline 411652098581201 & LC9-I & $3 / 31 / 2000$ & 1330 & .06 & .071 & $<.01$ & .121 & .37 \\
\hline \multirow[t]{2}{*}{411648098581301} & LC9-J & $3 / 31 / 2000$ & 1235 & .113 & .53 & $<.01$ & .181 & .55 \\
\hline & & $7 / 21 / 2000$ & 1300 & $<.050$ & .43 & $<.01$ & .259 & .79 \\
\hline \multirow[t]{2}{*}{411619098581001} & LCLS-1 & $4 / 06 / 2000$ & 1030 & .67 & 8.58 & .05 & 1.84 & 5.7 \\
\hline & & $7 / 24 / 2000$ & 1420 & .598 & 9.49 & .04 & 1.61 & 4.9 \\
\hline \multirow[t]{2}{*}{411637098581001} & LCMW 1-D & $3 / 28 / 2000$ & 1240 & 1.29 & .033 & .02 & .082 & .25 \\
\hline & & $7 / 24 / 2000$ & 1210 & 1.31 & $<.020$ & $<.01$ & .053 & .16 \\
\hline \multirow[t]{2}{*}{411637098581002} & LCMW1-M & $3 / 28 / 2000$ & 1525 & .698 & .022 & $<.01$ & .055 & .17 \\
\hline & & $7 / 24 / 2000$ & 1250 & .875 & $<.020$ & $<.01$ & .045 & .14 \\
\hline \multirow[t]{2}{*}{411637098581003} & LCMW1-S & $3 / 28 / 2000$ & 1615 & $<.050$ & .063 & $<.01$ & .088 & .27 \\
\hline & & $7 / 24 / 2000$ & 1330 & $<.050$ & .055 & $<.01$ & .068 & .21 \\
\hline \multirow[t]{2}{*}{411656098582701} & LCMW2-D & $3 / 29 / 2000$ & 0925 & 1.5 & $<.020$ & .01 & .056 & .17 \\
\hline & & $7 / 24 / 2000$ & 0850 & 1.48 & $<.020$ & $<.01$ & .054 & .17 \\
\hline \multirow[t]{2}{*}{411656098582702} & LCMW2-M & $3 / 29 / 2000$ & 1040 & 1.55 & $<.020$ & .02 & .067 & .21 \\
\hline & & $7 / 24 / 2000$ & 0940 & 1.5 & $<.020$ & .01 & .068 & .07 \\
\hline \multirow[t]{2}{*}{411656098582703} & LCMW2-S & $3 / 29 / 2000$ & 1155 & $<.050$ & .037 & $<.01$ & .119 & .36 \\
\hline & & $7 / 24 / 2000$ & 1020 & $<.050$ & .03 & $<.01$ & .128 & .39 \\
\hline \multirow[t]{2}{*}{411706098581001} & LCPS-1 & $3 / 29 / 2000$ & 1450 & 2.24 & $<.020$ & $<.01$ & .047 & .14 \\
\hline & & $7 / 21 / 2000$ & 1450 & 2.55 & $<.020$ & $<.01$ & .049 & .15 \\
\hline \multirow[t]{2}{*}{411709098540101} & SRGP-1 & $3 / 30 / 2000$ & 0900 & .104 & $<.020$ & $<.01$ & .201 & .62 \\
\hline & & $7 / 20 / 2000$ & 0930 & .073 & $<.020$ & $<.01$ & .178 & .55 \\
\hline
\end{tabular}


门 응

究备

造

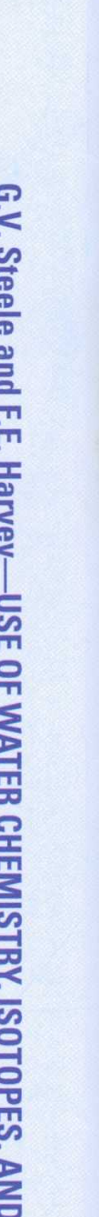

